\title{
Estudio sobre el marco jurídico audiovisual en Latinoamérica. Parte 5: la identificación y el uso de metadatos en las obras audiovisuales
}

\author{
$* * * *$ \\ Gustavo Schötz \\ Universidad Austral \\ gschotz@austral.edu.ar
}

\begin{abstract}
Resumen
Las obras audiovisuales son accesibles al público por diversos mecanismos de distribución, tradicionalmente llamadas "ventanas". Inicialmente, la sala de cine fue el primer lugar donde la obra era exhibida, a la que luego se sumó la televisión. Ambos canales tienen prácticas establecidas respecto a la identificación de la obra, usos y territorios autorizados, audiencia o taquilla, así como de sus autores, titulares de derechos y participantes, sean estos directores, guionistas, productores, actores, músicos o bailarines, entre los principales. La información para la gestión de este tipo de obras es sumamente relevante. En el ámbito digital, la explotación multiplataforma y multiterritorial requiere nuevas estrategias de gestión, la cual se basa en datos. El presente estudio analiza cómo debería consolidarse un sistema informativo en el ámbito digital, haciendo uso de los metadatos, los identificadores universales, las marcas de agua y las huellas digitales, de modo que se consoliden bases de datos interoperables en beneficio de todos los participantes y del público.

Palabras clave: derecho de autor, derechos conexos, obra audiovisual, plataformas digitales, Convenio de Berna, TODA, TOIEF, sociedades de gestión colectiva, metadatos, identificadores universales, marcas de agua, huellas digitales, inteligencia artificial, bases de datos, ISAN, EIDR, medidas tecnológicas de protección, gestión digital de derechos.
\end{abstract}




\title{
The Identification and Use of Metadata in Audiovisual Works
}

\begin{abstract}
Audiovisual works are accessible to the public through various distribution mechanisms, traditionally called "windows". Initially, the movie theater was the first place where the work was exhibited, later joined by television. Both channels have established practices regarding the identification of the work, authorized uses and territories, audience or box office, as well as its authors, rights holders and participants, be they directors, screenwriters, producers, actors, musicians, dancers, among the main ones. The information for the management of this type of works is extremely relevant. In the digital environment, multiplatform and multi-territorial exploitation requires new management strategies based on data. This study analyzes how an information system should be consolidated in the digital domain, making use of metadata, universal identifiers, watermarks and digital fingerprints, so as to consolidate interoperable databases, for the benefit of all participants and the public.

Key words: copyright, related rights, audiovisual works, digital platforms, Berne Convention, WCT, WPPT, collective management organizations, metadata, universal identifiers, watermarks, fingerprints, artificial intelligence, databases, ISAN, EIDR, technological protection measures (TPM), digital rights management (DRM).
\end{abstract}

\section{A identificação e utilização de metadados em obras audiovisuais}

\section{Resumo}

As obras audiovisuais são acessíveis ao público através de vários mecanismos de distribuição, tradicionalmente chamados "janelas". Inicialmente, o cinema foi o primeiro local onde a obra foi exibida, a que mais tarde se juntou a televisão. Ambos os canais estabeleceram práticas relativas à identificação da obra, usos e territórios autorizados, audiência ou bilheteira, bem como os seus autores, titulares de direitos e participantes, sejam eles realizadores, argumentistas, produtores, actores, músicos, bailarinos, entre os principais. A informação para a gestão deste tipo de obras é extremamente relevante. Na esfera digital, a exploração multiplataforma e multiterritorial requer novas estratégias de gestão, que se baseiam em dados. Este estudo analisa como um sistema de informação deve ser consolidado no domínio digital, fazendo uso de metadados, identificadores universais, marcas de água e impressóes digitais, de modo a consolidar bases de dados interoperáveis, para benefício de todos os participantes e do público.

Palavras-chave: direitos de autor, direitos conexos, obras audiovisuais, plataformas digitais, Convenção de Berna, TODA, TOIEF, organizaçôes de gestão colectiva, metadados, identificadores universais, marcas de água, impressóes digitais, 
inteligência artificial, bases de dados, ISAN, EIDR, medidas de protecção tecnológica (TPM), gestão de direitos digitais (DRM).

\section{Introducción ${ }^{1}$}

Este informe es parte del Estudio sobre el marco jurídico Latinoamericano y la distribución de contenidos audiovisuales en el ambiente digital, parte integrante del Proyecto Piloto sobre el Derecho de Autor y la Distribución de Contenidos en el Entorno Digital, presentado por el Brasil al Comité de Desarrollo y Propiedad Intelectual de la Organización Mundial de la Propiedad Intelectual (OMPI, CDIP/22/15 Rev.) (en adelante, "el Proyecto"). En particular, el Proyecto se propone sensibilizar a los creadores y partes interesadas sobre las normas nacionales existentes y evaluará las cuestiones que se plantean actualmente al derecho de autor y los derechos conexos en el mercado audiovisual digital de los países participantes: Argentina, Brasil, Costa Rica, Ecuador, Perú y Uruguay. ${ }^{2}$

Una vez que la obra audiovisual (OA) ha sido producida y comienza la explotación, en cualquiera de sus formatos y canales de distribución, su identificación es relevante en diversos momentos y para distintos objetivos; por ejemplo, para que puedan ejercerse los

1 Descargo de responsabilidad: el presente estudio se encargó como parte del Proyecto Piloto sobre Derechos de Autor y Distribución de Contenido en el Entorno Digital del Comité de la OMPI sobre Desarrollo y Propiedad Intelectual (CDIP). Este documento no tiene por objeto reflejar las opiniones de los Estados Miembros ni de la Secretaría de la OMPI. Este trabajo fue publicado en: Schötz, G. (10 de noviembre de 2020). Estudio sobre el marco jurídico audiovisual en Latinoamérica. Parte 5: la identificación y el uso de metadatos en las obras audiovisuales. Organización Mundial de la Propiedad Intelectual, disponible en la página de la OMPI, Work Undertaken Under Development Agenda Projects (wipo.int).

2 El Estudio sobre el marco jurídico Latinoamericano y la distribución de contenidos audiovisuales en el ambiente digital es compuesto de las siguientes partes: Parte 1: El modelo de negocio de las OTT en Latinoamérica; Parte 2: Estudio sobre el marco jurídico en Latinoamérica; Parte 3: Aspectos prácticos de la autoría de obras audiovisuales extranjeras; Parte 4: Prácticas contractuales en el sector audiovisual; y Parte 6: Métodos de medidas alternativas de solución de controversias aplicados a los modelos de negocio de las OTT. 
derechos de los titulares. En un entorno digital y global que permite que la OA pueda ser utilizada de modo simultáneo en distintas plataformas por distribuidores y usuarios de cualquier país, se requiere un seguimiento preciso sobre dichos usos.

El reporte se propone entender y explorar posibles soluciones para resolver los cinco problemas básicos relativos a la información y los metadatos: a) retraso en la recopilación y carga de datos; b) falta de datos; c) pérdida de datos; d) contaminación e inconsistencia de datos; y e) volumen de datos. ${ }^{3}$ Haremos hincapié especialmente en la simplificación de la gestión de la información de las OA para reducir los costos asociados a la distribución de contenidos. El incremento de las audiencias, además de productos de calidad, requiere ampliar los canales de distribución, lo cual puede significar pérdida de control y de ingresos. Por otra parte, la distribución a través de múltiples plataformas requiere que la información y las bases de datos resulten interoperables.

La ausencia de información sobre la circulación de las obras es un problema más acuciante para los pequeńos productores de los países objeto de este Proyecto. Si bien potencialmente el mercado digital permite que una obra pueda ser disfrutada universalmente -doblaje o subtitulado mediante-, en realidad es muy difícil que el público acceda a ella sin información adecuada. Y, si llegado el caso, la obra fuera disfrutada en muchas jurisdicciones, la falta de información no les permitiría a los titulares obtener el beneficio debido por tales usos.

Este informe se centrará en los datos y metadatos de las obras audiovisuales producidas y distribuidas profesionalmente. Quedan por tanto excluidos los contenidos generados por los usuarios prosumidores (User Generated Content, UGC), aun cuando puedan ser considerados obras audiovisuales, ya que no constituye una producción en el sentido técnico-comercial.

\section{Importancia de la información que identifica la obra audiovisual}

Tal como ya se estableció en la Parte 1 de ese estudio (Audiovisual OTT business models in Latin America: Recent trends and

3 Cfr. Colitre (2019). 
future evolution), el activo básico y la ventaja competitiva primaria de cualquier plataforma son los contenidos, es decir, las obras audiovisuales y otros programas que conforman su oferta. ${ }^{4}$ Esta se suele presentar como catálogo, con la información básica que permite la elección por parte del consumidor de una película, el episodio particular de una serie, un documental, un programa de televisión ya emitido o incluso un videoclip. De aquí que, como se puso de manifiesto en la Parte 4 del estudio sobre Contratos, los requerimientos de uniformidad en los metadatos suele ser una exigencia de los contratos con las plataformas de video on demand (VOD).

Contar con información adecuada es crucial ante la ingente cantidad de contenidos. En el ambiente digital, la oferta es enorme, ya sea real o potencialmente considerada. Desde el lado del consumidor, una plataforma cuenta con una variedad y cantidad de contenidos que hace difícil al usuario encontrar exactamente lo que busca o prefiere. Las búsquedas y elecciones de cada usuario son, a su vez, la materia prima de los algoritmos que permiten retroalimentar el consumo y sugerir nuevas opciones de acuerdo con géneros, artistas o idiomas. ${ }^{5}$ La información sobre consumo también permite personalizar la publicidad que el usuario recibe, para los casos de plataformas AVOD (advertising video on demand) o para que las plataformas dirijan la publicidad o los patrocinantes asignen la pauta publicitaria, en los casos de cableoperadores que utilizan TVEverywhere.

Desde el punto de vista de la plataforma, el volumen y la diversidad de las OA requieren información pertinente para identificar y organizar su oferta, lo cual es parte de su servicio y condición de éxito. Por parte del productor, la cantidad y variedad también le plantean un uso adecuado de la información, ya que él mismo dispone de una oferta diversa en competencia con otros titulares, por lo cual procura darles mayor visibilidad a los contenidos propios y así lograr el favor del público. ${ }^{6}$

4 Sin embargo, junto con el contenido, la distribución se ha convertido en la razón de éxito. A decir de un académico, "Content is the king and distribution is the King-kong”, respecto a la relación entre contenidos, distribución y las preferencias de los usuarios, cfr. Valor (2018).

5 Cfr. Covington et al. (2016). También Herrero Subías et al. (2018).

6 La información que la plataforma pone a disposición del público puede tener 
Por otra parte, los mismos contenidos pueden y suelen estar disponibles en más de una plataforma al mismo tiempo. Aquí también la información juega un papel relevante para facilitar la competencia o interacción entre las diversas plataformas, tanto en servicio del público como para que los productores puedan decidir cuál será la ventana de disponibilidad más apropiada. De igual modo, la información también es necesaria para identificar los titulares de un contenido del que se desea disponer y así negociar la incorporación de la obra a los catálogos de plataformas y organismos de radiodifusión. Estos problemas no son exclusivos de la industria audiovisual, pero por tratarse de un mercado de desarrollo más reciente que otros -el musical por ejemplo-, la situación resulta más compleja. ${ }^{7}$ De aquí que sea tan relevante el rol de los agregadores para la organización de la información y los metadatos.

Frente a estos problemas, pareciera que las tecnologías del big data y data mining brindarían una solución asequible. De hecho, lo sería si los datos de las obras, catálogos y repertorios estuvieran estandarizados y fueran de fácil acceso. La información sobre cada contenido y la organización de los datos, tanto para la oferta como para la ejecución real de las obras, es compleja. Como ya se analizó en la Parte 2 del estudio sobre el Marco Jurídico, los derechos exclusivos de autorizar y prohibir la explotación de la obra audiovisual son de gestión individual y se encuentra consolidada en el productor. Sin embargo, no siempre se trata de un único titular, ya que, por la aplicación de los principios de independencia y territorialidad de los derechos, algunos podrían ser cedidos para diferentes territorios o modalidades de explotación, sea de modo permanente o temporal. ${ }^{8}$

De acuerdo con cada modelo de negocio, se requerirán autoriza-

un valor agregado relevante. Por ejemplo, Amazon Prime Video incluye la función X-Ray, que permite ver en tiempo real la música que se está ejecutando o los artistas que participan de determinada escena. Cfr. https:/www. amazon.com/primeinsider/video/pv-xray-tips.html.

7 Cfr. Schaefer (2020).

8 La territorialidad no se fundamenta solo en el principio de maximización de las ganancias mediante la fragmentación de los mercados, sino también en limitaciones regulatorias o preferencias culturales del público. Cfr. Valor (2018, p. 21). 
ciones previas y contratos, los cuales incluyen cláusulas que en muchos casos establecen pagos en función de la tasa de uso de las OA disponibles en las plataformas OTT (Over the Top). Si las licencias son individuales sobre una o más obras, estas deben ser identificadas previamente. En ese caso, los titulares de la OA indican cuáles son las obras objeto de la autorización, junto con la determinación precisa de los medios, formatos y territorios en los que las obras podrán ser distribuidas, incluyendo en algunos casos horarios y cantidad de emisiones. La información y metadatos, por tanto, también son una solución al problema de la cadena de derechos y a las incertidumbres sobre titularidad y alcance de la explotación.

Además de los intereses de los productores, público y plataformas en el uso de la información, también se deben considerar los derechos exclusivos o de simple remuneración de gestión colectiva. Junto con los derechos del productor sobre la obra, coexisten los derechos que conservan otros titulares, como guionistas, directores y compositores de la banda musical, o bien intérpretes audiovisuales o musicales. ${ }^{9}$ Por ejemplo, los derechos por la retransmisión de las obras contenidas en las señales de aire, que está a cargo de las sociedades de gestión colectiva de cada país. Estos derechos dependen de cada jurisdicción de acuerdo a cómo se haya establecido su ejercicio. Así, en Uruguay, hasta noviembre de 2019, los guionistas y directores de obras audiovisuales no tenían derechos de remuneración ya que se presumían cedidos al productor. Con la modificación introducida en la Ley 9739, los titulares mencionados, aun habiendo cedido los derechos al productor, conservan un derecho de remuneración por la comunicación pública. ${ }^{10}$

9 Cfr. Xalabarder (2018). También Despringre et al. (2015).

10 República Oriental del Uruguay, Ley 9739, artículo 29, de acuerdo con la actualización, "Los autores de las obras musicales o compositores tendrán derecho a recibir una remuneración por la comunicación pública de la obra audiovisual, incluida la exhibición pública de películas cinematográficas, así como el arrendamiento y la venta de los soportes materiales". Se consagra, asimismo, en forma independiente, el derecho a una remuneración en iguales términos en favor de los directores y guionistas. Para el ejercicio de este derecho, los directores y guionistas podrán constituir una entidad de gestión colectiva conforme a la Ley 9739, de 17 de diciembre de 1937, en la 


\section{Si los costos de administración se incrementan por falta de información fiable, la recaudación puede ser antieconómica.}

Desde la perspectiva de estos derechos, el uso de información consistente posibilita un reparto de derechos más rápido, fiable y eficaz, especialmente por las sociedades de gestión colectiva (SGC) y otras entidades de recaudación, ya que facilita la integridad y el conocimiento del repertorio administrado. ${ }^{11}$ Esto es de especial relevancia cuando las sumas devengadas por una explotación dispersa pueden ser pequeñas en cada territorio, pero relevantes en la sumatoria. Si los costos de administración se incrementan por falta de información fiable, la recaudación puede ser antieconómica. De aquí que un resultado deseable del uso uniforme de la información podría ser la asignación precisa de los derechos recaudados y la reducción del "no identificado" cuando una plataforma realice pagos sin indicar el origen de esos fondos y no pueda identificarse a qué OA deben atribuirse. No menos importante es la utilidad de contar con información adecuada y homogénea para prevenir o resolver reclamos por los eventuales dobles pagos que podrían realizar las plataformas que deben remunerar a titulares de derechos en distintos territorios por la misma obra.

Por tanto, la información para el uso de las obras en las plataformas de VOD es relevante tanto desde el punto de vista de los derechos de gestión individual como de los de gestión colectiva. En

redacción dada por la Ley 17616, de 10 de enero de 2003, pudiendo delegar la recaudación de dicha remuneración en otra entidad de gestión colectiva de creadores. Tanto la remuneración para los autores de obras musicales o compositores como para directores y guionistas tendrán carácter irrenunciable e inalienable. Cuando la obra audiovisual sea publicada, comunicada o distribuida al público por el productor en forma no comercial, no onerosa, no corresponderá el pago de dicha remuneración.

11 Las Reglas Profesionales de la CISAC (Confederación Internacional de Sociedades de Autores y Compositores), por ejemplo, indican que las SGC "deben basar su reparto en la utilización efectiva de las Obras o, de no ser posible, en base a una muestra estadísticamente válida de la utilización efectiva de las Obras..." (\#18.a). 
los supuestos de licencias de repertorio o blancket license, los titulares o las SGC que los representan deben proveer la información de las obras incluidas bajo su gestión, también en los casos de licencias colectivas extendidas.

De este modo, de acuerdo con el tipo de contrato, las plataformas OTT, en cuanto usuarios, deben informar sobre el uso real de las obras. Incluso cuando las OA son de titularidad de la misma plataforma o hubieran adquirido los derechos de modo pleno deben disponer de la información sobre el uso real de las obras para informar a las SGC que administran derechos de gestión colectiva, ya sean de autores o de intérpretes.

La información debe segmentarse por territorios, ya que estos derechos de gestión colectiva son administrados y distribuidos territorialmente, también para los supuestos de licencias multiterritoriales. Los datos que identifican cada OA del catálogo, sus titulares y los derechos, serán utilizados para la gestión de la recaudación y distribución de dichos derechos, dependiendo de los distintos usos y plataformas de distribución, considerando cada territorio de modo independiente. Por tanto, la información resulta indispensable para la explotación adecuada del catálogo: cualquiera sea el modelo de negocio, los titulares deberían recibir los derechos devengados en todo el mundo por cualquier tipo de uso autorizado. ${ }^{12}$ La situación es más compleja cuando una plataforma tiene distintas fuentes de ingresos, ya que las regalías deberían considerar todos los canales de distribución. ${ }^{13}$ De aquí que se escuchen voces que abogan por una mayor transparencia informativa sobre el uso de obras y sus remuneraciones en el entorno digital. ${ }^{14}$

La información también es relevante en los casos de usos no auto-

12 Esto también se aplica al contenido generado por el mismo usuario (user-generated content) cuando utilice obras de terceros, como es el caso de la música en Tik-Tok, Instagram y otras redes sociales o plataformas.

13 Respecto a la tendencia a la integración vertical, pero la concomitante diversificación de opciones para el usuario, cfr. Christopher Vollmer (2018). Esta diversificación de opciones disponibles para el usuario por parte de un mismo proveedor se ha denominado "estrategia multiplataforma". Cfr. Doyle (2010).

$14 \mathrm{Al}$ respecto, cabe mencionar la propuesta que el GRULAC (Group of Latin 
rizados, sean aislados o prácticas habituales de piratería. Debería ser posible identificar la obra utilizada de modo ilegítimo para solicitar el cese de dicho uso o bien reclamar las indemnizaciones que correspondan. De hecho, los regímenes jurídicos que tienen mecanismos de notice and take down coinciden en exigir la identificación de la obra y su titularidad para suspender o dar de baja los contenidos en presunta infracción. ${ }^{15}$

La identificación de las obras tiene un beneficio adicional al permitir un conocimiento acabado e íntegro del patrimonio cultural, como se analizó en el estudio sobre el Dominio Público de este Proyecto. Las OA que se encuentran en el dominio público constituyen un problema reciente, pero creciente, ya que las tecnologías permiten digitalizar y disponer de contenidos históricos. A esto se agrega la compleja situación de las obras huérfanas, que si bien podrían estar en el dominio privado, se desconoce o no se puede hallar a su titular y, por lo tanto, se dificulta o se hace imposible su difusión y explotación. ${ }^{16}$ La información de las obras también es relevante para poder cumplir con regulaciones, como por ejemplo obligaciones de clasificación de contenido por edades, las calificaciones de los organismos de control o bien para cumplir e informar sobre las "cuotas de pantalla".

America and Caribbean Countries) presentó en el SCCR (Standing Committee on Copyright and Related Rights) de la OMPI por iniciativa de Brasil. Allí se indicó que se debe realizar un "análisis y debate del papel de las empresas que hacen uso en el entorno digital de obras protegidas y su modo de actuación, incluyendo la verificación del nivel de transparencia en los negocios y la cuantía de la remuneración correspondiente a los derechos de autor y derechos conexos a los distintos titulares de esos derechos" (WIPO SCCR/31/4, 1 de diciembre de 2015). Este aspecto fue abordado por el artículo 19 de la Directiva (UE) 2019/790 del Parlamento Europeo y del Consejo de 17 de abril de 2019 sobre los Derechos de Autor y Derechos Afines en el Mercado Único Digital.

15 Por ejemplo, la Section 512(3) de la Digital Millenium Copyright Act de los Estados Unidos. Cfr. Rostama (2017, p. 43).

16 Cfr. Van Gompel y Bernt Hugenholtz (2012). 


\subsection{La información de la obra audiovisual desde su creación y las diversas explotaciones}

Como ya se ha señalado en otros informes que forman parte de este Proyecto, las tecnologías digitales transformaron la cadena de valor y la logística de la distribución de las OA. Desde la creación y la posproducción de contenidos hasta la distribución y el consumo, han aparecido nuevas oportunidades para todos los interesados, incluyendo un público que desea disponer de contenidos en cualquier tiempo y lugar. Pero las oportunidades también implican desafíos, como interacciones más complejas en la cadena de valor y una explosión en la cantidad de contenidos disponibles. La digitalización de catálogos de la época analógica también es un asunto importante, porque la long tail ${ }^{17}$ de explotación de esas obras se extiende en el tiempo y en el espacio. Otro tanto se puede decir con los sistemas automáticos de subtitulado, que permiten acceder a nuevos públicos a bajo costo, aun considerando la imperfección de los resultados.

Como ya se indicó en la Parte 2 del estudio, al momento de negociar la explotación de los contenidos, el productor necesita demostrar la cadena de derechos de su obra. En el Estudio de Caso 5 sobre el clearence de derechos, el productor es responsable de justificar la titularidad de la obra final, lo cual también incluye la autorización o cesión de los autores de obras originarias incorporadas al audiovisual o que le permitieron producirla, como los derechos de los guionistas y del director, del autor de la banda musical o las autorizaciones de música sincronizada, así como la autorización de los intérpretes de la música original, tanto del director de la orquesta como de otros intérpretes de voz o instrumentos. Otro tanto se puede decir del "libre deuda" con los sindicatos de actores y otros intervinientes que realizan aportes en relación de empleo. En su caso, también será necesario el certificado de cumplimiento del organismo financiero o de promoción. En el caso de Argentina, por ejemplo, el Instituto

17 Se entiende por long tail al entorno en el que los canales de distribución digital les permiten a las empresas promover y vender una mayor variedad de productos de lo que hubiera sido posible en los canales físicos. Como resultado de esta mayor variedad de productos disponibles para la venta, cabría esperar que la distribución de las ventas se desplazara hacia una mayor variedad de productos de éxito. Cfr. Kumar et al. (2014). 
Nacional de Cine y Artes Audiovisuales (INCAA) emite una resolución en el expediente de subsidio o crédito con la calificación final de la obra audiovisual. En el caso de Brasil, para recibir la financiación se solicita el registro de la obra en la Biblioteca Nacional y el "número de producto brasileño" en la Agência Nacional do Cinema (ANCINE).

Todos estos instrumentos jurídicos constituyen la denominada "documentación", que le será requerida al productor al momento de celebrar los contratos de explotación, que si bien se suelen denominar de "cesión de derechos", en realidad son autorizaciones para una explotación exclusiva de la obra, limitada a usos específicos en un territorio y por un plazo. Puede tratarse de la obra original o de una adaptación.

Terminada la OA, en la etapa de posproducción es el momento de introducir la información que la identifica, así como a todos los participantes, en cualquiera de los formatos: MPEG, Windows Media, DVB ATSC, MXF. La información queda incorporada en medios físicos, flujos digitales y archivos digitales, entre otros. La mejor práctica es que todos los datos se integren mediante el uso de identificadores universales, ya que la posible monetización de esos contenidos a través de una cantidad creciente de canales de distribución requiere el uso de estándares e interoperabilidad de los sistemas. La "interoperabilidad" se define como la característica de un sistema o red informática para interactuar, intercambiar y utilizar información con un sistema o red independiente y externo. De aquí la necesidad de contar con un estándar de la industria ampliamente adoptado en todas las OA y su uso en la gestión de la información que efectúe cada actor del ecosistema. El identificador universal debería ser utilizado en los contratos de explotación, junto con el título de la OA.

El uso de identificadores universales presenta distintas utilidades, como, por ejemplo: 


\section{UTILIDADES DEL USO DE IDENTIFICADORES}

1) Indicar esos números a las emisoras cuando una película o una serie se licencia a un organismo de radiodifusión, para que los reportes sean más precisos al evitarse el error en la carga manual de datos.

2) Al entregar las OA a las plataformas y a los distribuidores digitales, incluir las listas de obras disponibles para la licencia y sus metadatos, a fin de permitir la automatización y reducir los riesgos de errores operativos.

3) Facilitar el tracking de las entregas y comunicaciones a y desde las casas de posproducción y el servicio de los proveedores que realizan el subtitulado y el doblaje.

4) Proporcionar a las guías y proveedores, como los medidores de audiencia, los metadatos que representan los repartos, sinopsis y horas de emisión.

5) Conformar repertorios de modo más ágil y preciso, especialmente cuando se requiere el registro de derechos en las SGC.

6) En caso de que se cargue la información relativa a la música de la OA, facilita el seguimiento de los derechos de autores e intérpretes musicales.

7) Individualizar las obras en los contratos de distribución y licencia; gestionar el contenido de las bases de datos para automatizar la presentación y el intercambio de datos.

8) Rastrear el rendimiento de la OA en cada ventana y recopilar estadísticas.

9) Facilitar la gestión, el descubrimiento y el licenciamiento del catálogo y los contenidos, en particular de pequeñas y medianas producciones.

10) Facilitar la identificación de contenidos ilícitamente distribuidos en línea.

Cuanto más homogénea sea la información disponible y cuanto más se extienda el uso de identificadores universales, mayor será la consistencia informativa y la facilidad de la gestión de derechos, ya que de esos identificadores surgirán los metadatos que permiten la gestión del catálogo. La insuficiente o deficiente gestión de los metadatos provoca falta de información. De aquí que no puedan ser interoperables y no permitan la integración y el escalado, generando islas de datos, lo cual se agrava por el manejo confidencial de la información. A su vez, esto puede dar lugar tanto a la duplicación en la gestión de derechos como a la ausencia de esta por contratos que no se reportan debidamente. Con ciclos de vida de los contenidos más largos y complejos, la información debe ser confiable y accesible en tiempo real. ${ }^{18}$

18 Cfr. Mindtree (s.f.). 


\subsection{Cuál es la información necesaria para administrar las $O A$}

Históricamente, no se ha establecido un estándar universal para recopilar e informar los datos de las OA. En esto ha incidido en parte la falta de obligatoriedad del registro de las obras, derivado del principio de ausencia de formalidades del artículo 5.2 del Convenio de Berna. Adicionalmente, se debe considerar el principio de territorialidad de los derechos, en base al cual cada país tiene sus propios mecanismos probatorios sobre la titularidad de la obra.

\section{Los objetivos que se propuso el Film Registration Treaty (FRT) siguen siendo de plena actualidad.}

Este proceso histórico dio como resultado que la información disponible sobre las OA cambie de territorio en territorio y dependiendo de cada "ventana", de acuerdo con el grado de madurez de la industria y con la disposición de recursos en cada jurisdicción. Sin embargo, alguna homogeneidad se advierte desde la necesidad de identificar de modo único la obra en el mercado de distribución física, ya que la exhibición internacional de las obras cinematográficas requiere una identificación precisa en los contratos y ante los organismos regulatorios. Desde los inicios, el título de la película fue el recurso básico utilizado por los productores, lo que llevó a enfrentar dos problemas: la homonimia y la necesidad de modificar dichos títulos en función del territorio de exhibición, ya sea por razones idiomáticas, comerciales, culturales o marcarias. ${ }^{19}$

La información sobre la titularidad y derechos sobre la obra audiovisual en el ámbito internacional fue motivo de estudio y actividad legislativa multilateral a cargo de la OMPI mucho antes del advenimiento del entorno digital, lográndose un resultado que quedó trunco. Me refiero al Tratado sobre el Registro Internacional de Obras Audiovisuales (Tratado sobre el registro de películas o Film Registration Treaty, FRT). ${ }^{20}$ Dicho Tratado preveía la constitución

19 Cfr. Negro Alousque (2010).

20 Adoptado en Ginebra el 20 de abril de 1989, disponible en: https://www. wipo.int/export/sites/www/treaties/en/documents/other_treaties/frt-treaty. pdf. Para un análisis detallado de sus disposiciones, cfr. World Intellectual 
de una unión internacional, creaba un registro internacional y otorgaba reconocimiento y valor probatorio a las constancias del Registro (artículo 4) (Ficsor, 1991, pp. 761 y ss.) Los objetivos que se propuso el FRT siguen siendo de plena actualidad, los cuales se pueden ver en su Preámbulo: 1) aumentar la seguridad jurídica en las transacciones relacionadas con las obras audiovisuales; 2) mejorar el proceso de creación de obras audiovisuales y la circulación internacional de esas obras; 3) contribuir a la lucha contra la piratería de las obras audiovisuales. ${ }^{21}$

En lo que respecta al objeto de este informe, el FRT establece en el artículo 3 (4) que los registros en la base de datos podían ser consultados públicamente, de acuerdo con los procedimientos y contenidos del artículo 7. El Tratado contó con la firma o adhesión de 24 países y la ratificación de 14, entrando en vigor el 27 de febrero de 1991. Sin embargo, en la reunión de la Asamblea de la Unión del FRT en 1993 se decidió que hasta que la propia Asamblea no tomara cualquier otra decisión al respecto, se suspendía la aplicación del Tratado. En las reuniones de las Asambleas de la OMPI, en 2000, se decidió que no se convocaría a la Asamblea de la Unión del FRT a menos que hubiera una petición expresa para hacerlo. ${ }^{22}$

La preocupación por la identificación uniforme de la OA, por tanto, tiene sentido por razones jurídicas, comerciales y de gestión. Entre las jurídicas, la identificación del titular de los derechos en determinado territorio y la certeza sobre los derechos bajo explotación importa también a los fines del recurso a remedios legales contra la piratería.

Desde lo comercial, en el entorno analógico la recaudación más importante para las OA siempre fue la taquilla por la exhibición en salas (theatrical). En esa ventana, el exhibidor debe informarle al distribuidor sobre las entradas vendidas y la recaudación total. Otro tanto está obligado a hacer el exhibidor con el ente de promoción de la actividad cinematográfica, dependiendo de cada país. ${ }^{23}$ También,

\footnotetext{
Property Organization (WIPO) (1990).

21 Cfr. Kovacs (1991, pp. 105-116).

22 Estatus del Tratado disponible en: https://www.wipo.int/export/sites/www/ treaties/es/documents/other_treaties/frt-parties.pdf.

23 INCAA en Argentina, ANCINE en Brasil, ICCA (Instituto de Cine y Creación Audiovisual) en Ecuador, DAFO (Dirección del Audiovisual, la
} 
considerando un entorno analógico, la información sobre las obras audiovisuales era y sigue siendo muy relevante en la actividad de los organismos de radiodifusión. Si bien la radiodifusión es un acto de explotación primario, en el que por lo general es el productor quien autoriza la inclusión de su obra en la señal portadora de programas, también es necesario recabar la información para la retransmisión o redifusión de dichas señales, además de la necesidad de informar a los otros titulares de derechos por la comunicación pública.

La pregunta que busca responder este informe, para el entorno digital, se refiere a cómo se miden e informan las nuevas taquillas. En el caso de la información disponible en las OTT, la situación es diversa, ya que cada plataforma y de acuerdo con el modelo de negocio dispone de diferentes catálogos, los que administra de acuerdo con sus necesidades (Gilchrist y Luca (2017). Los modelos mayormente propietarios o de contenido exclusivo, como Netflix o Disney+, organizan la información bajo parámetros diferentes a aquellos que funcionan bajo licencias o publicidad. En la Parte 1 del estudio sobre el modelo de negocio OTT quedó claro que el punto más crítico es el caso de las TVOD (transaction video on demand), en las que el consumo es por pago individual de cada contenido. Algo similar ocurre en los casos de AVOD, siendo necesario remunerar por la cantidad de visualizaciones de modo proporcional a la publicidad consumida y el tráfico originado por ese contenido. Por el contrario, en los supuestos de SVOD (subscription video on demand), los reportes al productor requieren menos detalles, ya que por lo general la plataforma tomó el riesgo mediante la inversión en la producción o en la adquisición de los derechos. Finalmente, en los modelos de TV Everywhere, si bien por lo general no se deben emitir reportes al productor en relación con una determinada tasa de consumo, indirectamente las remuneraciones se relacionan con la audiencia, ya que el valor de cada segundo de publicidad y el acumulado del período refleja las preferencias del público, manifestado en el rating.

Desde el punto de vista de la gestión colectiva de derechos, la falta de uniformidad territorial en la información afecta la recaudación, la

Fonografía y los Nuevos Medios) en Perú, ICAU (Instituto Nacional del Cine y el Audiovisual del Uruguay) en Uruguay. 
distribución y la reciprocidad. Por otra parte, los diferentes niveles de madurez de la gestión colectiva en cada país, así como entre sociedades de un mismo territorio, puede conducir a la falta de actualización en la organización y disponibilidad de los datos. Los ecosistemas regionales o nacionales funcionan a distintas velocidades. Cuando se trata de la recaudación de derechos por comunicación pública, la brecha informativa entre territorios se produce por varios factores. En algunos casos, la SGC es incipiente y la recaudación comienza por los organismos de radiodifusión, por tratarse de un mecanismo más reconocido a nivel mundial. ${ }^{24}$ En esa ventana en particular, un repertorio detallado no suele ser necesario para recaudar, aunque sí lo sea para distribuir. De aquí que el enorme esfuerzo que significa tener una base de datos completa e integrada da lugar a la implementación progresiva, considerando las dificultades y gradualidad en la implantación de una nueva entidad. También se debe mencionar que los titulares de derechos en muchos casos no comprenden la necesidad de dar de alta sus obras y tener la documentación al día. En estos países, fortalecer el sistema colectivo de información es imperioso.

\section{La preocupación por la identificación uniforme de la OA, por tanto, tiene sentido por razones jurídicas, comerciales y de gestión.}

En resumen, la información necesaria para la gestión de las OA deberá considerar los diversos actores, intereses y funciones que presta dicha información. Sin perjuicio de esas diversas necesidades y de acuerdo con cada etapa del flujo informativo, se debería contar con los datos necesarios para hacer un completo seguimiento de la explotación y usos de la OA y gestionar los derechos de los distintos titulares, así como la determinación del dominio público o la resolución de los problemas que plantean las obras huérfanas. Una información adicional es el territorio de la visualización, mediante la identificación del IP nacional del usuario o del suscriptor, ya que en muchos casos la plataforma puede ser accedida desde distintos 
territorios sin limitaciones ni segmentaciones geográficas. En otros casos, los contratos con los titulares de la obra solo permiten que la plataforma ofrezca esa obra en ciertos territorios, lo cual tiene que ver con otros contratos o con traducciones o subtitulados, o bien regulaciones sobre los contenidos de las plataformas relacionados con el orden público de cada jurisdicción.

Así, la información facilitaría la resolución de muchas de las dificultades presentadas en la Parte 2 sobre el marco jurídico de este Proyecto, considerando que en los países de la región la obra audiovisual es una obra en colaboración y no una obra colectiva. La falta de homogeneidad en la información aumenta la incertidumbre, ya de por sí inherente al tipo de obra. Por tanto, como indicación general, todo dato que se refiera a un interés de ejercicio de los derechos, recaudación, reparto o respeto de derechos morales debería figurar en la información. Estos datos deberían ser:

- Título de la obra, en los distintos idiomas y alfabetos de acuerdo con el país de exhibición.

- Características de la producción: duración de la OA, lugares de producción, fecha de finalización, de estreno, categoría de la obra (largometrajes, series, documentales, cortometrajes, multimedia, entre otros).

- Nombre e identificación comercial de los productores y coproductores.

- Titular de los derechos, con indicación de los territorios de explotación.

- Modos de explotación o derechos concedidos, especialmente el de puesta a disposición, y plazos de inicio y finalización para cada uno de ellos.

- Autores: guionistas, director, compositores de la banda musical o de la música preexistente sincronizada, ilustradores y dibujantes.

- Intérpretes audiovisuales, tanto de la versión original como de los actores de doblaje para las versiones adaptadas.

- Autores y editores musicales, intérpretes musicales y titulares de los fonogramas de la música preexistente sincronizada.

- Versiones: subtitulado, doblado a cierto idioma, versiones para televisión, para medios de transporte, para discapacitados visuales o auditivos. 
- Información regulatoria, como la edad de la audiencia.

- Contenidos relacionados, como el "detrás de cámara", trailers o escenas no incluidas en la versión final.

- Información relativa al soporte, para los sistemas jurídicos que establecen derechos sobre el videograma, independientes a los del productor audiovisual.

- Números o códigos que representen la información anterior.

\section{Los metadatos pueden definirse como los datos que representan y describen los atributos de un recurso, en este caso, un objeto audiovisual.}

\subsection{De la información a los metadatos en las OTT}

Gran parte de esta información se encuentra adosada a la misma OA, lo cual tradicionalmente se hace a través de los denominados "créditos". Sin embargo, no toda la información de los créditos será necesaria a los fines de la gestión de la OA ni forma parte de los números estándar internacionales. ${ }^{25}$ Muchas veces, la identificación de la obra por un dato o código uniforme podrá ser suficiente si luego esa información puede ser complementada en un segundo paso mediante su vinculación a una o más bases de datos.

Actualmente, en los formatos digitales, la información indicada se incorpora como metadatos en el código de cada obra en lenguaje binario. Los metadatos pueden definirse como los datos que representan y describen los atributos de un recurso, en este, caso un objeto audiovisual. ${ }^{26}$ También pueden estar recolectados en una base

25 Así, por ejemplo, los nombres de muchos participantes que figuran en los créditos no estarán en la identificación de la OA disponible en una plataforma de OTT, como directores de fotografía, diseńadores de arte, vestuaristas, maquilladores, diseñadores de efectos especiales, escenógrafos, entre otros. Esto se debe a que sus aportes, en caso de tener contenido creativo, son cedidos al productor como resultado de un contrato de trabajo o por cesión a "tanto alzado" y no hay derechos de remuneración a gestionar luego al momento de la explotación.

26 Cfr. International Association of Sound and Audiovisual Archives, https:// www.iasa-web.org/task-force/7-metadata. Para el concepto de metadatos en 
de datos separada, con o sin vínculo con la obra. Hay dos tipos de metadatos: por una parte, los llamados descriptive metadata tienen relación con el acceso, uso y disfrute de la obra y son los usualmente utilizados por los buscadores o por los motores internos de las plataformas cuando un usuario realiza una búsqueda. Por otra parte, están los administrative metadata, referidos a permisos de distribución, titularidad, participantes y contratos. Estos últimos son relevantes para la administración de derechos. ${ }^{27}$

La carga del contenido mismo y la información que lo identifica se hace a través de los mecanismos establecidos por las plataformas, que no son uniformes ya que cada una recupera e interpreta los datos de distinto modo. Aunque los metadatos estén incorporados en un formato estándar, como el XML (extensible markup language), cada una los extrae y aprovecha de acuerdo con su propio flujo de trabajo, tanto por la arquitectura y modelo de negocio de cada una de ellas como por las medidas de seguridad que deben adoptar los productores (partners) para que los contenidos no se difundan fuera del ecosistema de la plataforma. ${ }^{28}$

A modo de ejemplo, cuando Amazon Prime Video (www.primevideo.com) adquiere o resulta licenciataria de una OA para su distribución, establece cómo debe presentarse el conjunto de metadatos que identifican cada contenido. El listado de metadatos y el formato de estos son propios de esa plataforma, de acuerdo con las especificaciones técnicas predispuestas. ${ }^{29} \mathrm{El}$ partner ingresa de modo personalizado y realiza la carga siguiendo el procedimiento establecido. Además de los datos generales, luego se agregan requerimientos particulares por el territorio de distribución, ligados por lo general al idioma y al subtitulado, lo que incidirá en la monetización del contenido. El idioma de los metadatos junto con el nombre del título,

general y su uso en el ámbito digital, cfr. Baca (2016).

27 Cfr. Rendina (s.f.).

28 A modo de ejemplo, aquí se pueden ver las medidas de seguridad impuestas por Netlix: https://partnerhelp.netflixstudios.com/hc/en-us/articles/1500000132801-Netflix-Studio-InfoSec-Guidebook-for-Productions\#h_01ES2124VV6F6DWY8HRKVC210F.

29 Cfr. https://videodirect.amazon.com/home/help?topicId=GG5QNX4NA2MEWRAA\&ref_=avd_sup_GG5QNX4NA2MEWRAA. 
la sinopsis, el audio o los subtítulos de cierto contenido determinan las ubicaciones en las que se puede publicar. Todos ellos deben coincidir con el idioma de los metadatos para poder ser distribuido en una ubicación determinada. El proceso debe repetirse tantas veces como idiomas de publicación estén disponibles. La indicación es la siguiente:

Opciones de disponibilidad. Puede seleccionar en qué territorios el título estará disponible y cómo estará disponible para los clientes de Amazon. Recuerde que las ubicaciones aptas dependen del idioma de los metadatos que haya seleccionado al añadir el título. Para obtener más información, consulte Información sobre los ingresos.

De aquí surgirá, por ejemplo, si el contenido estará disponible para venta y alquiler (TVOD) o también en la plataforma Prime (SVOD).

Entre los metadatos se incluye qué formatos están disponibles para ese contenido, de modo que la plataforma pueda adaptar la distribución al dispositivo del usuario, ya sea mediante detección automática o por elección del consumidor. Los metadatos en general se contrastan con la información disponible en Internet Movie Database (IMDb), una base de datos que suele contar con información ya verificada. Cuando el productor, la plataforma o el agregador deban dar de alta un contenido para el que no se cuenta con metadatos suficientes, se pueden utilizar los servicios de agencias como Gracenote (www.gracenote.com), que cuenta con un centro de metadatos y toma a su cargo verificar la conformidad con IMDb. Además, Gracenote agrega descriptores conceptuales sobre el contenido mismo, los que facilitan las búsquedas del consumidor y el procesamiento de la información mediante machine learning, para, por ejemplo, permitir la comparación de catálogos de distintas plataformas. Como se indicó en el estudio de caso sobre los agregadores, estos no pueden tener un margen de acierto inferior al 97\% de assets (obra, doblaje, subtítulos, etc.) para continuar siendo aceptado en una plataforma SVOD. 


\section{Gustavo Schötz}

Estudio sobre el marco jurídico audiovisual en Latinoamérica. Parte 5: la identificación y el uso de metadatos...

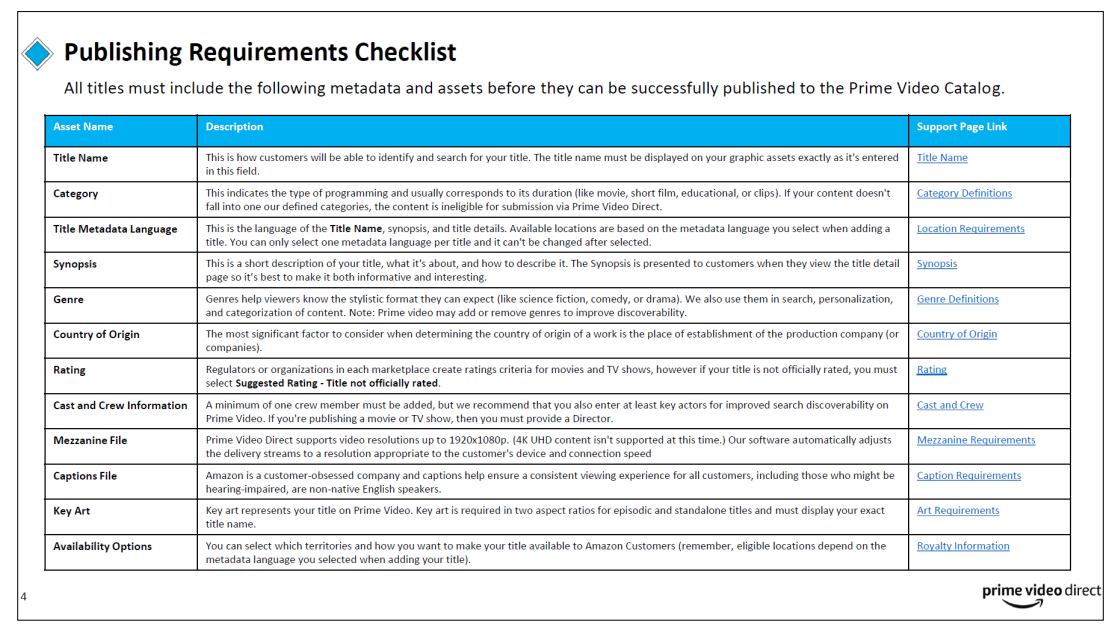

Figura 1. Metadatos establecidos por Amazon Prime Video (fuente: PowerPoint Presentation (media-amazon.com)).

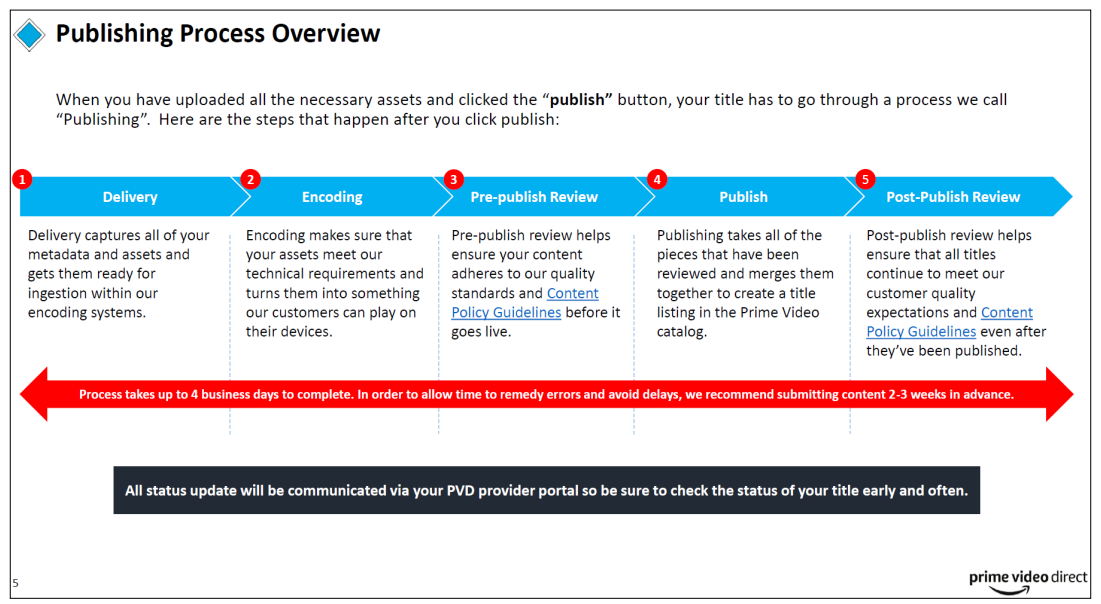

Figura 2. Proceso de publicación establecido por Amazon Prime Video (fuente: PowerPoint Presentation (media-amazon.com)).

Los requisitos no son iguales en todas las plataformas; los productores, distribuidores o agregadores podrán utilizar las API disponibles en las bases de datos para importar la información existente. ${ }^{30}$ En caso contrario, deberán realizar la adaptación o carga manual de acuerdo con las herramientas que se utilicen en cada caso para

30 API es el acrónimo de application programming interface. Son conjuntos de 
compartir datos. Por ejemplo, el Netflix Metadata Template requiere como primer dato el EIDR de la OA. ${ }^{31}$ Entre otros requerimientos, los datos dependerán de que se trate de producciones originales o licenciadas, como el caso de "Netflix Original Series". Hay una directa relación entre el modo de presentar los créditos y los metadatos. ${ }^{32} \mathrm{~A}$ su vez, el productor o su agente deben incluir descriptores relacionados con la calificación del contenido: si el lenguaje es inconveniente, si hay escenas de sexo o abuso de drogas, si es apropiado para menores de edad, entre otros. Esas calificaciones pueden ser importadas desde un organismo oficial de calificación que disponga de una API para intercambio de datos.

Finalmente, se deben subir igualmente las imágenes o portadas por las cuales la OA o el episodio va a ser identificado, de acuerdo con los requisitos técnicos de cada plataforma. Los distintos contenidos, con orígenes muy diversos, requieren cierta uniformidad para facilitar al consumidor la búsqueda y la fidelización a la plataforma.

Un aspecto a tener en cuenta es que los metadatos cumplen además una función técnica en relación con la arquitectura del sistema y la distribución del contenido y no solo para su identificación a los fines administrativos, comerciales o jurídicos. Esto se debe, entre otras cosas, a que el delivery del contenido no se hace mediante la descarga de un único archivo o flujo de datos, sino la combinación sincronizada de imagen, sonido y subtitulado, aun cuando desde el lado del usuario aparezca un solo título en la playlist. Los metadatos que identifican cada archivo o flujo permiten la adecuada combina-

solicitudes estandarizadas que permiten que diferentes programas informáticos se comuniquen entre sí. Las API establecen la forma adecuada para que un desarrollador solicite servicios de un programa. Están definidos por los programas receptores, facilitan el trabajo con otras aplicaciones y permiten que los programas se comuniquen a través de diferentes plataformas informáticas. Cfr. Encyclopaedia Britannica, https://www.britannica.com/ technology/API.

31 Cfr. https://partnerhelp.netflixstudios.com/hc/en-us/articles/215620267-All-Metadata-Templates.

32 Para los productores, agregadores, distribuidores y todos los actores del ecosistema de Netflix es de aplicación obligatoria el Full Licensed Technical Specification, disponible en: https://partnerhelp.netflixstudios.com/hc/enus/articles/215148917-Full-Licensed-Technical-Specification-v9-1. 
ción y ensamblado. Por tanto, los mismos metadatos son el recurso técnico que facilita la edición de los contenidos y la entrega de un producto que cumpla con los requisitos de calidad y las necesarias adaptaciones territoriales o idiomáticas. ${ }^{33}$ Tal vez este sea el principal obstáculo para lograr una plena uniformidad y universalización del dataset y formato de los metadatos: los requisitos técnicos de cada plataforma y el modelo de negocio.

En el caso de Netflix, por ejemplo, utilizan el Interoperable Master Format (IMF) como mecanismo estandarizado de entrega de contenidos. ${ }^{34} \mathrm{El}$ procedimiento comienza con el ingestion system, que procura asegurar la integridad de los archivos que contienen imagen y sonido junto con los metadatos que los identifican. Luego, los archivos verificados se decodifican y se vuelven a codificar para configurar los flujos de salida, incluyendo los DRM correspondientes. El proceso permite combinar en una línea de tiempo distintos flujos que requieren ser sincronizados. El esquema general puede verse a continuación:

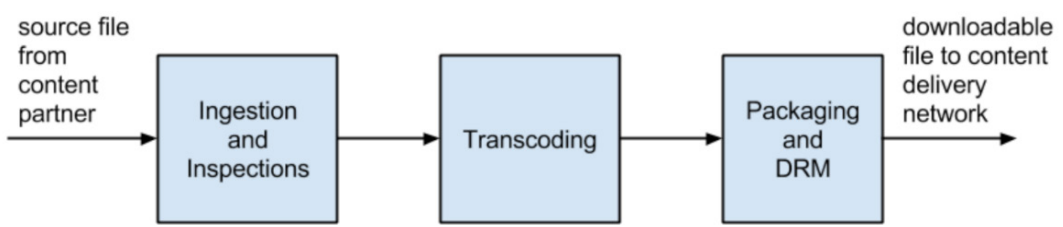

Figura 3. (Fuente: The Netflix Tech Blog). ${ }^{35}$

Los metadatos incorporados a la OA se encuentran protegidos como "información sobre la gestión de derechos" en los términos del artículo 12 del Tratado de la OMPI sobre Derecho de Autor (WCT o TODA), en la medida en que "estén adjuntos a un ejemplar de una obra o figuren en relación con la comunicación al público de una obra”.

33 Respecto a la necesidad de incluir datos específicos para las versiones de acuerdo con requerimientos territoriales, cfr. https://netflixtechblog.com/ imf-a-prescription-for-versionitis-e0b4c1865c20.

34 Cfr.https://partnerhelp.netflixstudios.com/hc/en-us/articles/360002018547-Interoperable-Master-Format-IMF-Overview.

35 Cfr. https://netflixtechblog.com/the-netflix-imf-workflow-f45dd72ed700. 


\subsection{Normativa en la región que se refiere a la información para la gestión de derechos}

Los aspectos informativos de la OA e incluso la obligación de hacer uso de sistemas de información homogéneos por el uso de obras audiovisuales en las plataformas OTT puede estar previsto en la legislación vigente, ser parte del cumplimiento de contratos o bien objeto de órdenes judiciales en casos particulares.

Desde el punto de vista legislativo y judicial, estos aspectos cambian de jurisdicción en jurisdicción, debido a la territorialidad de los derechos. Dicho principio fue reconocido en la reciente reforma legislativa del Perú, cuando al sancionarse el nuevo régimen de promoción del cine se estableció que "La distribución de obras cinematográficas y audiovisuales que se realice a través de plataformas digitales, cuyo consumo final tenga lugar en el territorio nacional, se regula de acuerdo a lo previsto en las normas especificas peruanas" ${ }^{36}$ La norma mencionada, al indicar que "cuyo consumo final tenga lugar en el territorio nacional, se regula de acuerdo a lo previsto en las normas específicas peruanas", está ratificando la aplicación del principio de territorialidad. Las regulaciones nacionales, por tanto, podrían obligar a los usuarios a brindar información en el territorio de consumo final, así como los deberes y derechos de los titulares o sus representantes sobre los catálogos y repertorios.

\subsubsection{Obligaciones de registro}

El registro de las $\mathrm{OA}$ y los contratos no es un requerimiento de la normativa internacional, debido a que el artículo 5.2 del Convenio de Berna establece que "el goce y el ejercicio de estos derechos no estarán subordinados a ninguna formalidad y ambos son independientes de la existencia de protección en el país de origen de la obra”. Esta cláusula del Convenio es interpretada como una manifestación

36 República del Perú, Decreto de Urgencia 022-2019, que Promueve la Actividad Cinematográfica y Audiovisual, artículo 22.2, publicado en el $\mathrm{Di}$ ario Oficial El Peruano del 8 de diciembre de 2019, disponible en: https:// busquedas.elperuano.pe/download/full/3HemirU0aFaBk9_1N1ISaF. Énfasis agregado. 
del principio general de que la protección en derecho de autor es automática y nace con la creación. Sin embargo, el registro voluntario y declarativo cumple con finalidades jurídicas, sociales y económicas relevantes. ${ }^{37}$ Además del registro voluntario, disponible en todos los países objeto del estudio, en algunos casos existen también registros exigidos para ciertas finalidades públicas, como el fomento de la producción audiovisual, el control de taquilla, el cumplimiento de la "cuota de pantalla" o para verificar las restricciones por horario o edad para las OA emitidas por organismos de radiodifusión. Sin embargo, dentro de la finalidad de este estudio, también podrían considerarse funciones nuevas o ampliadas de estos registros para facilitar el funcionamiento de los mercados en el ámbito digital globalizado de contenidos. ${ }^{38}$

Encontramos algunas disposiciones nacionales que obligan a registrar la obra audiovisual a los fines de que el productor se beneficie de los regímenes de fomento, como es el caso de Perú. En Ecuador, el Instituto del Fomento a la Creatividad y la Innovación (IFCI, antes

37 La discusión respecto a las ventajas del registro de las obras protegidas por derecho de autor o bien la ausencia total de formalidades está lejos de haberse agotado. Muchas de las consideraciones respecto a las funciones y ventajas del registro - con especial referencia a la práctica de EUA- han sido analizadas por Gervais y Renaud (2013).

38 Cfr. Van Gompel (2011, p. 9). A modo de ejemplo, el registro de la OA en China facilita el combate de la piratería. La ley de comercio electrónico de China prevé en su artículo 42 que "Where IPR holders perceive an infringement of their IPRs, they have a right to notify e-commerce platform business operators to take necessary measures such as deleting, blocking or disconnecting links and terminating transactions or services. The notices shall include preliminary evidence relating to the infringement". La "evidencia preliminar" privilegiada es el registro de los derechos de autor, mediante simples y económicos procedimientos. Cfr. http://ipkitten.blogspot. com/2019/01/new-chinese-e-commerce-law-and-its.html. En 2018, se efectuaron 3457338 registros de derecho de autor en China. Adicionalmente, en ese país los registros facilitan el uso de los llamados content ID, que utilizan las plataformas de monitoreo de contenidos en la red con una eficacia mayor al 95\% en la baja de contenidos en infracción. Cfr. http://ipkitten.blogspot. com/2017/05/the-popular-china-copyright-monitoring.html. Para mayor información del sistema de baja de contenidos en China, cfr. Friedmann (2017). Énfasis agregado. 
ICCA) también requiere el registro previo de las OA en el Servicio Nacional de Derechos Intelectuales (SENADI) respecto a las obras que participan en el concurso de selección del Fondo Nacional de Cine. ${ }^{39}$ En Argentina hay que mencionar la obligatoriedad de la inscripción de los contratos: "La enajenación o cesión de una obra literaria, científica o musical, sea total o parcial, debe inscribirse en el Registro Nacional de Propiedad Intelectual, sin cuyo registro no tendrá validez" (artículo 53 de la Ley 11723). Si bien la norma pena de modo severo la falta de inscripción, la jurisprudencia y la doctrina han interpretado que el efecto es la falta de oponibilidad frente a terceros. ${ }^{40}$ Esta norma ha sido aplicada en casos de derecho sucesorio o concursos y quiebras de productores audiovisuales para determinar qué obras integran el patrimonio del productor. Además de esta norma genérica, el artículo 34 establece que "Las cesiones totales o parciales de derechos temporales o espaciales de explotación de películas cinematográficas sólo serán oponibles a terceros a partir del momento de su inscripción en el Registro Nacional de Propiedad Intelectual". De aquí que las inscripciones de contratos sean fundamentales en los clearence de la cadena de derechos, especialmente para la exhibición en salas extranjeras, aunque la información de estos contratos no figure luego en los metadatos incorporados en la OA.

Por su parte, Brasil exige que las OA de producción nacional sean registradas ante ANCINE como requisito previo para la obtención del número que las identifica con el Certificado de Producto Brasileiro (CPB). ${ }^{41}$ Para obtenlo hay que dar de alta información básica, como

39 Cfr. Resolución Nro. 012-DE-ICCA-2018, artículo 10.6, disponible en: http://www.creatividad.gob.ec/certificacion-de-origen-nacional-independiente-de-obras-cinematograficas-y-audiovisuales-para-personas-naturales/.

40 Cfr. Sommaruga (2017, pp. 93 y ss.). Los registros o inscripciones de contratos sobre la obra audiovisual resultan muy relevantes por cuanto algunas legislaciones los requieren para oponer esos derechos a terceros, en el caso de cesiones, situaciones vinculadas al derecho de familia (separaciones, divorcios, sucesiones hereditarias), procesos falenciales (quiebras y concursos), o bien el uso de la obra o sus derechos para estructuras financieras (fideicomisos, emisión de fondos de inversión).

41 Cfr. Passo a passo para emissão do CPB | Página de Lista | ANCINE | Agência Nacional do Cinema | Ministério do Turismo | Governo Federal. 
el título de la obra, categoría y tipo de obra, una sinopsis, duración, nombre de productores y coproductores con el porcentaje de titularidad de derechos de cada uno, director, otros autores (guión, música, ilustraciones), participantes (sonidistas, iluminadores, directores de fotografía), así como otras empresas de servicios contratadas para la producción de la obra. Se deben adjuntar asimismo los contratos celebrados en el proceso de producción y para su explotación, los que no se hacen públicos y sus términos solo están disponibles para los productores y otras partes interesadas. También se deben declarar los números de los expedientes iniciados para la aprobación de los fondos de fomento de ANCINE o del Fondo Sectorial del Audiovisual.

Los registros de ANCINE, a su vez, requieren el previo registro de la OA en la Biblioteca Nacional, que actúa como autoridad de registro de los derechos de autor para todo tipo de obras. El formulario para dicho registro es genérico y no contiene especificaciones para la OA que resulten útiles para la gestión de derechos. ${ }^{42}$

$\mathrm{El} \mathrm{CPB}$ es una prueba de origen brasileño y de que la OA es una producción independiente. El número del CPB debe utilizarse obligatoriamente para emitir los reportes sobre exhibición en salas de cine. Es el documento más importante para los productores, exhibidores, canales de televisión para demostrar: a) en el caso de una empresa productora que utilizó fondos públicos para la producción, que la obra es brasileña o brasileña/independiente y que cumple con los requisitos legales para ambas, es decir, adquirir la nacionalidad brasileña y utilizar los subsidios públicos de producción e incentivos fiscales; b) en el caso de un canal de televisión abierta o un canal de cable, que están cumpliendo con las cuotas obligatorias al emitir o exhibir contenido brasileño o brasileño/independiente. ${ }^{43} \mathrm{Si}$ bien el $\mathrm{CPB}$ muestra quiénes son los titulares de los derechos de una determinada obra audiovisual y su porcentaje, no hay más información a efectos de la propiedad intelectual.

42 Cfr. https://www.bn.gov.br/servicos/direitos-autorais. Aquí pueden consultarse los requisitos del formulario de registro: https:/www.bn.gov.br/sites/ default/files/documentos/diversos/2015/1208-registroouaverbacao/registro-ou-averbacao-579_0_0_0_0_0_0.pdf.

43 Cfr. https://www.gov.br/ancine/pt-br/assuntos/noticias/ancine-publica-duas-instrucoes-normativas-sobre-cpb-e-crt. 
Brasil exige además la obtención del Certificado de Registro de Título (CRT) a través del Sistema ANCINE Digital (SAD, http:// sad.ancine.gov.br), tanto para obras nacionales como extranjeras. El CRT tiene por finalidad demostrar que quien explota la OA pagó el tributo requerido para esa ventana o segmento de mercado específico. La ley brasileña exige que todos los agentes de la industria audiovisual paguen un impuesto destinado a financiar el fomento de la industria audiovisual (distribución, producción, etc.): es el llamado Fondo Setorial Audiovisual. Debe ser erogado antes de la exhibición pública. El SAD permite asociar el CPB en el registro de CRT y, de ese modo, se importa la información ya cargada. Se declara adicionalmente el segmento del mercado al que está destinada la OA, como exhibición en sala, TV abierta, TV paga y "otros mercados", que incluyen el TVOD y el SVOD. También se debe solicitar el CRT para obras de terceros que serán licenciadas, informando el período de la licencia y adjuntando el respectivo contrato.

\begin{tabular}{|c|c|}
\hline \multicolumn{2}{|c|}{ Certificado de Produto Brasileiro } \\
\hline \multicolumn{2}{|c|}{$N^{\circ} B 20-004844-00000$} \\
\hline \multicolumn{2}{|c|}{ 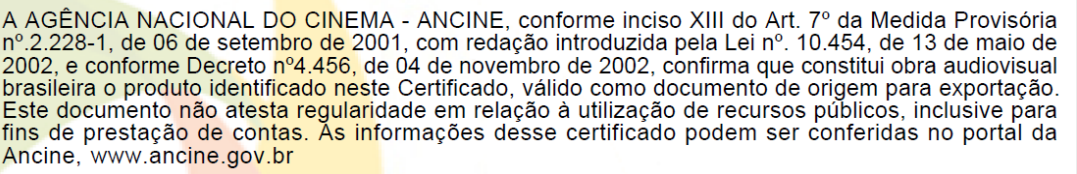 } \\
\hline Título Original & PROTETORES DA FLORESTA \\
\hline Classificação & BRASILEIRA INDEPENDENTE CONSTITUINTE DE ESPAÇO QUALIFICADO \\
\hline Tipo & DOCUMENTÁRIO \\
\hline
\end{tabular}

Figura 4. Ejemplo de CPB (fuente: ANCINE). 


\section{Gustavo Schötz}

Estudio sobre el marco jurídico audiovisual en Latinoamérica. Parte 5: la identificación y el uso de metadatos...

\begin{tabular}{|c|c|c|}
\hline Os capítulos/Ep & tios abaixo faz & ste certificado de $p$ \\
\hline Título Original & PROTETORES & STA \\
\hline CPB $N^{\circ}$ & B20-004844-0C & \\
\hline Temporada & Episódio $n^{\circ}$ & CPB $n^{\circ}$ \\
\hline $\begin{array}{l}01 \\
01 \\
01 \\
01\end{array}$ & $\begin{array}{l}001 \\
002 \\
003 \\
004\end{array}$ & $\begin{array}{l}\text { B20-004844-00001 } \\
\text { B20-004844-00002 } \\
\text { B20-004844-00003 } \\
\text { B20-004844-00004 }\end{array}$ \\
\hline
\end{tabular}

Figura 5. Ejemplo de CPB (fuente: ANCINE).

\section{CERTIFICADO DE REGISTRO DE TÍTULO CRT N ${ }^{\circ} 2020012554000005$}

Válido para o segmento de mercado

\section{COMUNICAÇÃO ELETRÔNICA DE MASSA POR} ASSINATURA (TV PAGA)

A AGÊNCIA NACIONAL DO CINEMA - ANCINE, conforme inciso XIII do art $7^{\circ}$ da Medida Provisória $\mathrm{n}^{\circ} 2.228-1$, de 06 de setembro de 2001, com redação introduzida pela Lei $\mathrm{n}^{\circ} 10.454$, de 13 de maio de 2002, atesta que o título abaixo identificado foi registrado nesta Agência.

\begin{tabular}{ll} 
Requerente & JACKIE SHOR PROJECTS - PROJETOS \\
CPB/ROE N & B20-001392-00000 \\
Título Original & CHOCOLIX-SEGUNDA TEMPORADA \\
\hline
\end{tabular}

Figura 6. Ejemplo de CRT (fuente: ANCINE).

\begin{tabular}{|c|c|c|}
\hline Título Original & \multicolumn{2}{|c|}{ CHOCOLIX - SEGUNDA TEMPORADA } \\
\hline CRT No & \multicolumn{2}{|l|}{2020012554000005} \\
\hline \multicolumn{2}{|c|}{ Válido para o segmento de mercado } & $\begin{array}{l}\text { COMUNICACCÃO ELETRÔNICA DE MASSA POR ASSINATURA } \\
\text { (TV PAGA) }\end{array}$ \\
\hline Episódio $n^{\circ}$ & CPB/ROE $n^{\circ}$ & CRT n ${ }^{\circ}$ \\
\hline $\begin{array}{l}1 \\
2 \\
3 \\
4 \\
5 \\
6 \\
7 \\
8 \\
9 \\
10 \\
11 \\
12 \\
13\end{array}$ & $\begin{array}{l}\text { B2000139200001 } \\
\text { B2000139200002 } \\
\text { B2000139200003 } \\
\text { B2000139200004 } \\
\text { B2000139200005 } \\
\text { B2000139200006 } \\
\text { B2000139200007 } \\
\text { B2000139200008 } \\
\text { B2000139200009 } \\
\text { B2000139200010 } \\
\text { B2000139200011 } \\
\text { B2000139200012 } \\
\text { B2000139200013 }\end{array}$ & $\begin{array}{l}2020-012554-00001-3 \\
2020-012554-00002-1 \\
2020-012554-00003-0 \\
2020-012554-00004-8 \\
2020-012554-00005-6 \\
2020-012554-00006-4 \\
2020-012554-00007-2 \\
2020-012554-00008-0 \\
2020-012554-00009-9 \\
2020-012554-00010-2 \\
2020-012554-00011-0 \\
2020-012554-00012-9 \\
2020-012554-00013-7\end{array}$ \\
\hline
\end{tabular}

Figura 7. Ejemplo de CRT (fuente: ANCINE). 
Sin embargo, estos registros a los que nos hemos referido y los números resultantes no cumplen con estándares internacionales y resultan poco útiles para la gestión de derechos en el ámbito digital. $\mathrm{Su}$ aplicación es solo a los fines administrativos o probatorios. $\mathrm{Si}$ bien configuran una base de datos de consulta pública, no generan metadatos que puedan servir para realizar un seguimiento de la $\mathrm{OA}$ en sus distintas explotaciones ni son interoperables. Una conclusión preliminar, por tanto, es que los registros de obras y contratos, en su estado actual, no cumplen con la finalidad de identificar universalmente la obra y los derechos resultantes para poder gestionar la explotación en el ámbito digital. Una posibilidad por considerar es que estos registros se articulen con otros de tal manera que integren un único flujo de información y bases de datos públicas en formatos interoperables.

\subsubsection{Obligación de emitir reportes por la explotación de las obras}

En los países objeto de estudio no se encuentra una norma equivalente a los artículos 17 y 19 de la Directiva sobre los Derechos de Autor y Derechos Afines en el Mercado Único Digital, la cual exige el envío de informaciones sobre el uso de la obra. ${ }^{44}$ En caso de existir algún tipo de obligación, esta debería surgir de los contratos entre productores y distribuidores con las plataformas. Como ya se destacó en la Parte 4 del estudio sobre las prácticas contractuales, no fue posible acceder a ninguno de ellos debido a la confidencialidad que suelen pactar las partes. Incluso en supuestos de gestión colec-

44 Directiva (UE) 2019/790 del Parlamento Europeo y del Consejo de 17 de abril de 2019 sobre los Derechos de Autor y Derechos Afines en el Mercado Único Digital, artículo 19. 1. "Los Estados miembros se asegurarán de que los autores y los artistas intérpretes o ejecutantes reciban periódicamente, y por lo menos una vez al ańo, teniendo en cuenta las características específicas de cada sector, información actualizada, pertinente y exhaustiva sobre la explotación de sus obras e interpretaciones o ejecuciones por las partes a las que hayan concedido licencias o cedido sus derechos, o de los derechohabientes de estos, especialmente en lo que se refiere a los modos de explotación, la totalidad de los ingresos generados y la remuneración correspondiente". 
tiva obligatoria de derechos, las mismas SGC o las plataformas no informan al público sobre los usos o recaudaciones, a diferencia de lo que sí ocurre con la taquilla de la exhibición en cines o incluso con la liquidación de derechos de los organismos de radiodifusión.

Sin embargo, la confidencialidad impuesta o negociada por una de las partes no debería ser un obstáculo para otros intereses legítimos de terceros, como el adecuado conocimiento de la tasa de uso de cada obra en los distintos canales de distribución. Así, la difusión de la taquilla de exhibición en salas cinematográficas, el rating alcanzado por un programa emitido por una señal televisiva, el público de un concierto son ejemplos de datos que no afectan la privacidad de los participantes o usuarios y brindan información adecuada para la gestión de derechos.

Por el contrario, sí hay conocimiento de los términos y condiciones de algunas plataformas, debido a que son públicos. Cuando una plataforma implementa una buena práctica o exige ciertos requerimientos para el acceso y disfrute, o bien establece términos y condiciones, en definitiva, estos documentos constituyen disposiciones contractuales, ya que requieren que los titulares o los usuarios acepten dichos términos y condiciones mediante su adhesión, como en el caso de Content ID de YouTube, que analizaremos más adelante.

Adicionalmente, también se debe considerar que la información de la OA o la incorporación de los metadatos en los masters es una exigencia de las plataformas, a los fines de que los contenidos puedan ser distribuidos de modo homogéneo. Dicha exigencia suele estar a cargo de los agregadores, como se advirtió en la Parte 4 sobre las Prácticas Contractuales y el estudio de caso sobre los agregadores, ambos parte de este Proyecto.

\subsubsection{Obligaciones informativas en relación con la gestión colectiva}

En algunos de los países objeto de este estudio se encuentran algunas disposiciones relativas a la información requerida para la gestión colectiva de derechos. En Brasil, la Ley 9610 del 19 de febrero de 1998, en su artículo $98 \$ 9$ (incluido por la Ley 12853 de 2013) establece que "Las asociaciones deben poner a disposición un sistema 
de información para la comunicación periódica, por parte del usuario, de la totalidad de las obras y fonogramas utilizados, así como para el seguimiento, por parte de los titulares de derechos, de los valores recaudados y distribuidos". ${ }^{45}$ Este acápite tiene relación con otras obligaciones a cargo de las SGC, en los $₫ 6,7$ y 8 , por las cuales las SGC deben

dar publicidad y transparencia, a través de sitios electrónicos propios, a las formas de cálculo y criterios de cobro, discriminando, entre otra información, el tipo de usuario, tiempo y lugar de utilización, así como los criterios de distribución de los valores de los derechos de autor recaudados, incluidas las planillas y otros registros de uso de las obras y fonogramas suministrados por los usuarios, excepto los valores distribuidos a los titulares individualmente. ${ }^{46}$

La misma legislación, en su inciso 4, indica que

El cobro será siempre proporcional al grado de utilización de las obras y fonogramas por parte de los usuarios, considerando la importancia de la ejecución pública en el ejercicio de sus actividades y las particularidades de cada segmento, conforme lo dispuesto en el reglamento de esta Ley.

Luego, en la reglamentación del Decreto 8469 del 22 de junio de 2015, se establece en el artículo 16:

Es responsabilidad de las asociaciones poner a disposición un sistema de información para la comunicación periódica, por parte del usuario, de la totalidad de obras, interpretaciones o ejecuciones, $y$ fonogramas utilizados. ${ }^{47}$

45 Texto del acuerdo con la traducción disponible en WIPO Lex: https://www. wipo.int/edocs/lexdocs/laws/es/br/br224es.pdf.

46 Artículo 98-B.I, incluido por la Ley 12853 de 2013.

47 Reglamentación de la Ley 9610 del 19 de febrero de 1998 y la Ley 12853 del 14 de agosto de 2013, para disponer sobre la gestión colectiva de derechos de autor. 
En un nivel legislativo inferior, encontramos la Instrucción Normativa No 1 del Ministerio de Cultura, de 4 de mayo de 2016, en la que se establece la obligación de informar por parte de los usuarios que realizan ejecución pública de obras musicales y fonogramas incluidos en producciones audiovisuales. Se encuentran alcanzadas las empresas de exhibición cinematográfica, las empresas distribuidoras de servicios de comunicación audiovisual de acceso condicionado y los proveedores de aplicaciones de internet. En el caso de las salas de cine, deben entregar a las SGC la información de las obras u otras producciones audiovisuales exhibidas en el mes anterior. Los operadores de servicios restringidos de TV deben informar la lista completa de los canales de programación distribuidos a los abonados, identificando el número de registro del programador o generador y el respectivo canal en ANCINE. En el caso de plataformas de internet, deben informar el título de las obras u otras producciones audiovisuales utilizadas en el territorio nacional.

Asimismo, en el artículo $3^{\circ}$ se indica que las SGC pueden obtener la lista completa de las obras y demás producciones audiovisuales nacionales difundidas en los canales de las empresas de programación del sitio de la Agencia Nacional de Cinematografía. Luego, en el artículo $4^{\circ}$, se establece cómo deben identificarse las obras musicales y fonogramas insertados en las obras y otras producciones audiovisuales nacionales. Respecto a la música incluida en obras audiovisuales de producción extranjera, la información será provista por las SGC del país de origen con quienes mantengan un acuerdo de representación recíproca. De modo complementario, la Instrucción Normativa No 2 del Ministerio de Cultura, de 4 de mayo de 2016, establece procedimientos complementarios para la recaudación por ejecución pública de obras, interpretaciones o ejecuciones y fonogramas en internet.

Otra norma relevante la encontramos en Ecuador, en el artículo 257 del Código INGENIOS, ${ }^{48}$ que indica:

Artículo 257.- De la obligación de llevar registro los organismos de radiodifusión, televisión o cable.- Todos los organismos de ra-

48 República del Ecuador (2016). 
diodifusión, televisión o cable y en general quienes realicen comunicación al público de obras, interpretaciones o ejecuciones, emisiones o fonogramas protegidos, con fines comerciales y que realicen una selección detallada de los materiales que comunican directamente al público, deberán llevar catálogos, registros o planillas mensuales en las que se registrará por orden de difusión, el título de las obras difundidas y el nombre de los autores o titulares de los derechos de autor y derechos conexos que correspondan y sean de su conocimiento. Dichos catálogos, registros o planillas deberán ser remitidos a cada una de las sociedades de gestión colectiva y a la entidad única recaudadora de los derechos por comunicación pública para los fines establecidos en este Capítulo. La sociedad de gestión colectiva deberá otorgar recibos o constancias que den cuenta de la recepción de los catálogos, registros o planillas de los que trata el presente artículo.

Dicho artículo se aplica a los organismos de radiodifusión y a los exhibidores en salas de cine. Sin embargo, es de dudosa aplicación a las OTT, ya que estas por lo general realizan puesta a disposición y no comunicación pública. Si bien para los autores la comunicación pública incluye la puesta a disposición (artículo 8 del TODA), no es igual para los titulares de derechos conexos, ya que ambos derechos están bien diferenciados (artículos 10 y 14 del TOIEF y artículos 10 y 11 del Tratado de Beijing). De acuerdo con la norma transcripta, los datos que deben incluir las planillas son muy básicos; sin embargo, nada impide que las SGC y los usuarios acuerden algún formato que permita identificar de modo inequívoco a las obras emitidas o comunicadas.

El Reglamento del Código INGENIOS cuenta también con una obligación informativa aplicable a las OA, en cabeza de las SGC. Por el artículo 115 están obligadas a crear y "mantener actualizada una base de datos con información clara y precisa de las obras, interpretaciones o ejecuciones, emisiones o fonogramas cuyos derechos de autor o derechos conexos gestionan...”. Deberá ser de acceso público y disponible en línea y constarán los titulares de las obras, las obras y las tarifas por cada tipo de utilización y categoría de usuario. 
También deberán disponer para conocimiento de sus socios los usos reportados por cada obra y los métodos aplicados para la distribución. ${ }^{49}$ Entendemos que esta norma también es aplicable a la gestión de derechos por usos de las OA en las plataformas digitales de VOD.

\subsection{La información sobre explotación de la obra en salas (theatrical)}

En el mercado audiovisual la primera ventana de explotación fue la sala de exhibición, el cinematógrafo. De acuerdo con la práctica, que no ha tenido grandes cambios en los aspectos esenciales desde sus inicios, el distribuidor, bajo autorización del productor, contrata con el exhibidor dueño o gestor de la sala, ya que es el titular/licenciatario del derecho exclusivo para un territorio, tiempo y tipo de uso determinado (Aft y Renault, 2011, p. 78).${ }^{50} \mathrm{El}$ contrato entre el productor o distribuidor y los exhibidores exige información puntual y precisa de la taquilla, ya que el modo usual de remunerar esa explotación es mediante un porcentaje de la recaudación.

Tanto la liquidación de dicha remuneración como las garantías y anticipos se suelen pactar en un porcentaje de la venta de tickets. La información es relevante porque, a su vez, impacta en otros contratos, como el de los productores, algunos actores y otros titulares que reciben un porcentaje de dichos ingresos, ya sea que se definan como brutos o netos. Por la gran cantidad de interesados en la información adecuada de los ingresos generados, el exhibidor debe informar diariamente la cantidad de entradas vendidas y a qué precio.

Adicionalmente, por tratarse de un mercado regulado, al menos en algunos de los países objeto de este estudio, los exhibidores tienen obligación de presentar una declaración jurada al organismo de promoción de la actividad fílmica. En el caso de Argentina, la declaración se denomina "F.700", de acuerdo a lo indicado en la Resolución 3785/2013 del INCAA, en la que informan toda la exhibición dia-

49 Ecuador, Acuerdo No. SENESCYT-2020-077, Reglamento de Gestión de los Conocimientos, disponible en: www.registroficial.gob.ec. Año II - No 1412, Quito, martes 22 de diciembre de 2020.

50 Asimismo, Moullier y Holmes (2007, pp. 77 y ss.). 
ria. ${ }^{51}$ Las películas se informan con el código de película que otorga el INCAA en la clasificación. La planilla la dispone la autoridad de fiscalización sin injerencia del productor. Actualmente, las planillas se suben digitalmente a la plataforma del INCAA.

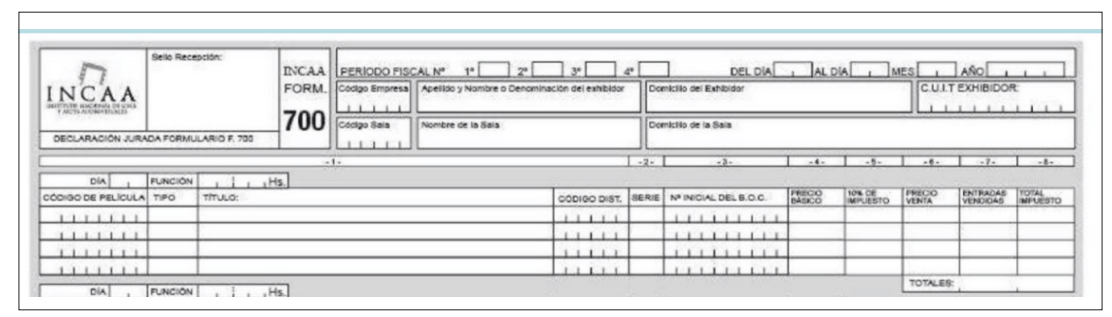

Figura 8. El modelo de información a brindar (fuente: INCAA).

La misma consideración cabe para Brasil respecto al cumplimiento de la cuota de pantalla de las salas de cine, establecido por el Decreto 10190, de 24 de diciembre de 2019, la que se verifica por medio del Sistema de Control de Boletería instrumentado por ANCINE, de acuerdo con la Instrucción Normativa 123, de 22 de diciembre de 2015. ${ }^{52}$ El exhibidor debe informar la taquilla diaria mediante el Sistema ANCINE Digital, en el que se identifican las obras de acuerdo con los códigos de registro de ANCINE. Los códigos alfanuméricos utilizados son el CPB y el ROE (Registro de Obra Estrangeira) para las obras audiovisuales extranjeras con fines comerciales. Como se puede ver, en los países objeto de este estudio los modos de identificar las obras no son universales y dificultan la gestión automatizada de la información.

Los cines, a su vez, por uso y costumbre informan diariamente las cifras que hizo cada una de las películas al fin del día a una empresa especializada en la captura y difusión de la información. En algunos casos se envían planillas y en otros los boleteros, al cerrar la caja, se comunican telefónicamente con personal de la empresa para informar las cifras. En caso de Argentina y Uruguay, el principal proveedor de este servicio es ULTRACINE (https://web.ultracine.com/),

51 El INCAA publica anualmente un anuario, disponible en: http://fiscalizacion.incaa.gov.ar/index_anuarios_2019.php.

52 Normativa disponible en: https://www.gov.br/ancine/pt-br/fsa. 
que actúa en nombre de los distribuidores. Esta empresa también publica sus anuarios.

Otro proveedor independiente de reportes de salas es COMSCORE. A Través de su producto COMSCORE International Box Office Essentials ${ }^{\circledast}$ (IBOE), esta empresa, de presencia global, reporta los ingresos de más del $90 \%$ de la industria cinematográfica mundial. ${ }^{53}$

Asimismo, es quien produce los informes de taquilla para DAFO, la autoridad peruana. El siguiente es un extracto de un informe de taquilla de Perú para 2019:

\begin{tabular}{|c|c|c|c|c|c|c|c|c|c|c|}
\hline Titulo & Distribuidora & Estreno & $\begin{array}{l}\text { Recaudación } \\
\text { (S/) }\end{array}$ & Asistencia & Género & $\begin{array}{l}\text { Pais de } \\
\text { origen } \\
\text { primario }\end{array}$ & $\begin{array}{l}\text { Pais de } \\
\text { origen } \\
\text { no } \\
\text { primario }\end{array}$ & \#Cines & \#Pantallas & Clasificación \\
\hline $\begin{array}{l}\text { La Peor de Mis } \\
\text { Bodas } 2\end{array}$ & COLOR & $01 / 01 / 2019$ & $2,153,390$ & 215,057 & Comedy & Peru & & 102 & 126 & A \\
\hline Máquinas Mortales & UPI & $01 / 01 / 2019$ & $1,184,834$ & 116,702 & $\begin{array}{l}\text { Science } \\
\text { Fiction }\end{array}$ & $\begin{array}{l}\text { New } \\
\text { Zealand }\end{array}$ & USA & 102 & 107 & M 14 \\
\hline No Mires & BFDT & $03 / 01 / 2019$ & 742,777 & 67,543 & Suspense & USA & & 47 & 51 & M 14 \\
\hline $\begin{array}{l}\text { Dragon Ball Super: } \\
\text { Broly }\end{array}$ & FOXI & $10 / 01 / 2019$ & $14,641,904$ & $1,332,137$ & Animation & Japan & & 102 & 422 & A \\
\hline Ya Veremos & BFDT & $10 / 01 / 2019$ & $1,893,737$ & 186,357 & Comedy & Mexico & & 76 & 84 & A \\
\hline La Mula & WBI & $10 / 01 / 2019$ & $1,045,861$ & 74,595 & Drama & USA & & 28 & 34 & M 14 \\
\hline $\begin{array}{l}\text { El Silbón: } \\
\text { Origenes }\end{array}$ & STARFLM & $10 / 01 / 2019$ & 112,213 & 15,221 & Horror & Venezuela & $\begin{array}{l}\text { Mexico, } \\
\text { USA }\end{array}$ & 24 & 31 & M 14 \\
\hline
\end{tabular}

Figura 9. Informe de taquilla en Perú (fuente: DAFO https://dafo.cultura.pel).

A los fines de informar a los productores y distribuidores, estos proveedores elaboran las "fichas técnicas" de cada película y para cada territorio. No utilizan números estándares internacionales como el ISAN, sino que cada distribuidor provee la información básica. Luego, la ficha se completa con los datos de cada versión local, como la calificación, duración, doblaje o subtitulado, incluso acudiendo a otras bases de datos como IMDb. Los reportes requieren que se acceda a todos los datos, de todos los cines y distribuidores y, en muchos casos, también con el detalle de cada función. Los reportes se envían principalmente al distribuidor, pero en ocasiones también se informa a los agentes o productores para los casos de distribución en varios países.

También se debe tener en cuenta la información necesaria para que las SGC puedan administrar los derechos gestionados colectiva-

53 Cfr. https://www.comscore.com/Products/Movies/International-Box-Office-Reporting. 
mente, ya sean exclusivos o patrimoniales de simple remuneración, sean de autor o conexos y a cargo de los exhibidores. Estos deben presentar la información a cada SGC, aunque con otra periodicidad y en diferente formato. A continuación, se puede ver un modelo de liquidación de derechos de comunicación pública en salas de cine de Argentina:

\begin{tabular}{|c|c|c|c|c|c|c|c|c|}
\hline \multirow{3}{*}{$\begin{array}{l}\text { CODIGO } \\
\text { INCAA }\end{array}$} & \multirow{3}{*}{ PELÍ́CULA } & \multirow{3}{*}{ DIRECTOR } & \multirow{3}{*}{ ORÍGEN } & \multirow{3}{*}{$\begin{array}{l}\text { VTA. } \\
\text { NETA }\end{array}$} & \multicolumn{3}{|c|}{ ARANCEL } & \multirow{3}{*}{$\begin{array}{l}\text { TOTAL } \\
\text { A } \\
\text { PAGAR }\end{array}$} \\
\hline & & & & & \multirow[b]{2}{*}{$* * * \%$} & \multirow[b]{2}{*}{$* * * \%$} & \multirow[b]{2}{*}{$* * * \%$} & \\
\hline & & & & & & & & \\
\hline & & & & & & & & \\
\hline & & & & & & & & \\
\hline
\end{tabular}

Tabla 1. Planilla de liquidación de taquilla.

Como se puede observar, los reportes por exhibición en salas no son uniformes y no se encuentran centralizados. En parte porque los destinatarios en dichos informes tienen objetivos diferentes, ya que, por ejemplo, los aranceles a pagar se sustentan en diferentes derechos. Pero la información básica, es decir, las entradas vendidas y a qué precio, debería ser coincidente, ya que, de lo contrario, la inconsistencia acarrearía problemas fiscales y de cumplimiento de la normativa autoral, amén del eventual incumplimiento contractual frente a las distribuidoras. ${ }^{54}$

\subsection{La información sobre la explotación de la obra en la radiodifusión}

La explotación del audiovisual mediante la radiodifusión es una actividad consolidada y madura. Cuando un productor negocia su obra o su repertorio individualmente con un organismo de radiodifusión o con un distribuidor, la información requerida es menor. Cada obra se identifica por su título y esto es suficiente a los fines de la celebración y ejecución del contrato de radiodifusión. En relación con esa obra o conjunto determinado de obras, se establecerá la cantidad de emisiones, fechas y horarios, medios (aire, cable, satélite), la eventual

54 En algunas jurisdicciones, la falsedad en los reportes acarrea además responsabilidad criminal como un caso especial de defraudación. 
posibilidad de que estén disponibles en diferido, medios adicionales en los que estará disponible la señal emitida, como IPTV, entre otras. Luego se establecerá una remuneración, ya sea una suma fija o asociada a la cantidad de emisiones. Eventualmente, llegada la liquidación del contrato o de uno de sus períodos, el organismo de radiodifusión informará la cantidad de emisiones y fechas, entre otros datos. No es necesaria otra información a los fines de ese contrato; así, por ejemplo, los organismos de radiodifusión, ya sea aire, cable o satélite, no suelen brindar datos de las audiencias de cada emisión, tampoco cuando cuenten con servicios paralelos de TVEverywhere.

El organismo de radiodifusión organiza su propia base de datos a los fines administrativos internos. Algunos distribuidores permiten obtener dicha información mediante el acceso restringido a sus sitios y bases de datos para que el radiodifusor disponga de la información de los títulos incluidos en algún contrato vigente. La base de datos del radiodifusor puede incluir el número de contrato, nombre del proveedor o distribuidor que licencia o cede la OA, la señal por donde se emitirá el programa o la película, el monto total del contrato, el monto de cada contenido en particular (en caso de que hubiera más de un programa por contrato), el periodo de vigencia de los derechos y los derechos territoriales. También se cargan las imágenes o cortes con los que la obra será anunciada o publicitada. En caso de organismos de radiodifusión que tienen distintas señales y por distintos medios, también se indicará la señal autorizada para cada emisión, así como la información sobre ejecución de las emisiones.

Todos estos datos son privativos del organismo de radiodifusión y no suelen utilizarse identificadores uniformes de las obras. La carga es manual en hojas de cálculo y, además del título, la información contiene datos del sello, productor, director, autor, cantidad de capítulos (en caso de telenovelas o series), productor ejecutivo, actores, país de origen, año de producción, género y duración en minutos, ya sea que se encuentre editada o no para su calificación y exhibición. Con esa información, el organismo de radiodifusión organiza su grilla o parrilla de contenidos (schedule) para cada señal, la que estará disponible para el área comercial del radiodifusor, anunciantes, cableoperadores o señales que retransmiten -tanto del país como del extranjero- y los servicios de medición de audiencia. Esa 
información se extracta de la base de datos propia y es muy básica: título, duración, horario, director, protagonistas. La organización de la pauta publicitaria surge de este schedule.

La base de datos del radiodifusor permite emitir reportes para los distribuidores en un listado mensual que indica el título y la fecha en la que fueron emitidos los programas contratados con ese distribuidor. Los distribuidores también pueden acudir a servicios independientes de auditoría de contenidos, quienes suelen brindar información equivalente, aunque enriquecida con la medición de audiencia.

La base de datos del radiodifusor también es utilizada para los reportes requeridos por autoridades regulatorias y entes públicos, tanto para justificar el cumplimiento de la cuota de pantalla como los requerimientos de calificación y horarios de protección al menor. Dependiendo de los países, esos reportes se pueden completar digitalmente mediante plataformas específicas, a las que la emisora accede y efectúa la carga de datos mediante el envío de una planilla de cálculo o la integración de un formulario. La información requerida por dichos entes reguladores es básica y no utilizan identificadores universales. Solo es relevante identificar la OA bajo el mismo título que utilizó el organismo de calificación del país respectivo.

Los reportes de cumplimiento se entregan ex post, pero también se requieren informes ex ante para la programación nueva. En este último caso, se informa el nombre del programa, la frecuencia, fecha y hora de comienzo y de finalización, género (película, periodístico, variedades, deportivo). En el caso de las películas, hay que indicar el título, si el programa está doblado y, en su caso, donde se efectuó el doblaje. También se detalla el origen, nacional o extranjero, indicando el país. En el caso de ser de origen nacional hay distintas opciones: propia del radiodifusor, producida por terceros localmente o por terceros foráneos. Si es de producción local a cargo de terceros, se debe mencionar a la productora. Cuando corresponda, se informa si se trata de una transmisión en vivo, diferida o compra directa. También se debe dar aviso de los cambios de programación.

En resumen, respecto a la información sobre las OA y otros contenidos de los organismos de radiodifusión, se advierte una práctica poco uniforme y la falta de uso de identificadores universales. 


\subsection{La radiodifusión y la gestión colectiva}

Dependiendo de cada territorio y del tipo de derechos, el organismo de radiodifusión debe informar a otros titulares, particularmente a las SGC, ya sea que gestionen derechos exclusivos o de simple remuneración. En estos casos, el detalle de la información podría ser mayor, ya que se deberá vincular cada obra audiovisual con los titulares de esos derechos. Por lo general, solo es necesario informar la emisión de la obra por su título y cada entidad luego se encarga de vincular esa obra con los titulares correspondientes, sean, guionistas, directores, productores, intérpretes musicales o audiovisuales, editores musicales o productores fonográficos. El repertorio de cada SGC contendrá la información necesaria para identificar a los titulares de derechos correspondientes a cada obra emitida por el organismo de radiodifusión. Si la obra está dada de alta en cada uno de los repertorios, la información del organismo de radiodifusión será utilizada para distribuir la recaudación de cada SGC. Si la SGC respectiva gestiona un repertorio universal o bien en el país funciona el mecanismo de la licencia extendida, la recaudación y asignación de los fondos se simplifica. Si, por el contrario, hay más de una entidad representativa del mismo tipo de derechos, será necesario asignar la recaudación en función del repertorio representado por cada una de ellas, salvo el caso de las llamadas "ventanillas únicas", como el ECAD en Brasil.

Debido a que los radiodifusores pagan los derechos de remuneración en función de los ingresos por publicidad o la cantidad de abonados sin atribuir los pagos a tal o cual programa en particular, normalmente se utilizan las grillas de programación para asignar la distribución de dichas recaudaciones. En el caso de cableoperadores o señales por satélite, no todas las señales están disponibles para todos los operadores. Cuando además la SGC aplique criterios de distribución ponderando la audiencia, cruzarán la información básica con los ratings informados por agencias especializadas como IBOPE, COMSCORE, Nielsen o KantarMedia. Los reportes de audiencia también utilizan el título de la obra de acuerdo con la grilla de programación informada por cada señal o bien recolectada por los reportes de dichas agencias.

En el caso particular de la música incluida en el audiovisual, el ra- 
diodifusor elabora los cue sheet de la programación propia y los envía a las entidades autorales. Puede ser música preexistente sincronizada o bien música compuesta especialmente para la programación. En el último caso, es usual también que si el organismo de radiodifusión es el productor del contenido y la música es original para sus programas, gestione el registro de las obras musicales en calidad de editor. Es la práctica que también siguen grandes productoras audiovisuales, como Netflix, Disney o Viacom. La obligación de declarar las obras incluidas siempre es del productor, sea el mismo radiodifusor, un productor externo o bien el productor originario de la OA. Uno de los datos más relevantes es indicar qué tipo de uso se le da a la música. En caso de ser incidental (background), la distribución es menor que respecto al tema de apertura o cierre de un programa.

Para el caso de los fonogramas comunicados públicamente a través de las señales radiodifundidas, la detección de cada fonograma está automatizada mediante mecanismos de fingerprints $\mathrm{y}$, por tanto, no es necesario utilizar los cue sheet. Veremos este tema con más detalle más adelante.

\section{Sistemas de gestión de información en el ámbito digital}

La falta de una referencia pública de la utilización de los identificadores existentes es actualmente una fuente importante de costos y fricciones para la industria audiovisual y los distribuidores digitales. En los flujos de datos que van desde la distribución hasta la generación de informes, la falta de uniformidad obliga a hacer coincidir manualmente los elementos en función de metadatos o del uso de esquemas privados, muchos de los cuales carecen de alcance universal. ${ }^{55}$

Como ya se indicó, el ámbito digital de explotación de las $\mathrm{OA}$ implica que para un mismo contenido puede existir una gran cantidad de licencias en muchos territorios con diferentes fechas de inicio. Algunos de los riesgos latentes son los siguientes:

55 El uso de identificadores universales, como el ISAN o EIDR, es una de las buenas prácticas recomendadas por la Independent Film \& Television Alli- 


\section{Gustavo Schötz}

Estudio sobre el marco jurídico audiovisual en Latinoamérica. Parte 5: la identificación y el uso de metadatos...

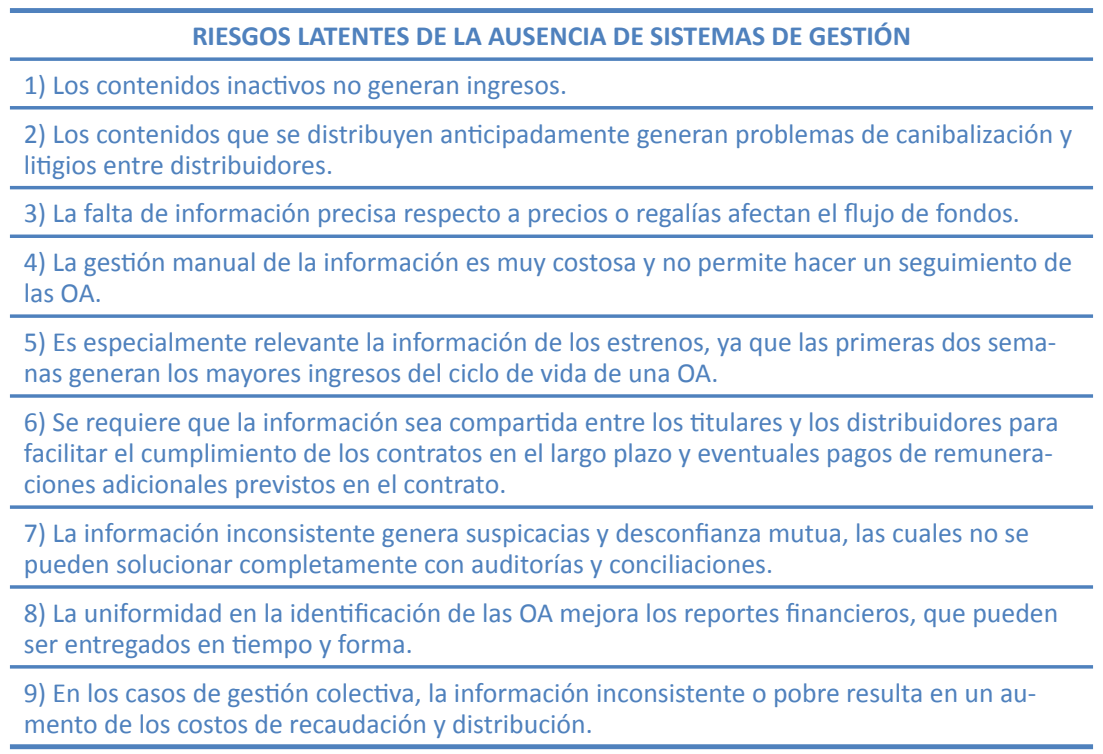

Una norma o estándar es una forma comúnmente acordada de hacer algo. Tienen por finalidad simplificar la gestión, aumentar la interoperabilidad, la eficacia y la eficiencia de cualquier interacción repetida. Suelen implementarse a través de documentos publicados que contienen especificaciones técnicas, reglas, directrices o definiciones. Ahorran costos de transacción y aumentan la eficiencia. Los estándares se elaboran por consenso entre los expertos y las partes interesadas de una industria y se adoptan voluntariamente. Debido a que la cadena de valor digital depende cada vez más de transacciones de alto volumen y bajo costo, solo el uso de estándares puede proporcionar la eficiencia operativa requerida. Como también se reducen los márgenes, solo una infraestructura global automatizada para procesar las transacciones basada en esas normas permitirá generar las inversiones financieras que requiere la implementación de esos mismos estándares.

De las distintas iniciativas y estrategias que procuran resolver los problemas informativos en el ámbito digital y salvar los vacíos o inconsistencias, la más importante es el uso de identificadores digitales

ance $(2015$, p. 13). 
universales. ${ }^{56}$ Veremos los mecanismos más desarrollados respecto a la gestión de las $\mathrm{OA}$.

\subsection{El código ISAN}

El instrumento más extendido para la información de OA es el denominado Código ISAN, acrónimo de International Standard Audiovisual Number (https://www.isan.org/). Es un código estándar desarrollado por la International Standard Organization (ISO), en particular la norma norma internacional ISO $15706 .{ }^{57} \mathrm{Su}$ administración está a cargo de ISAN-IA, una organización constituida por AGICOA (Asociación de Gestión Internacional Colectiva de Obras Audiovisuales, https://www.agicoa.org/index.html), CISAC (Confederación Internacional de Sociedades de Autores y Compositores, https://es.cisac.org/) y FIAPF (Federación Internacional de Asociaciones de Productores Cinematográficos), con sede en Ginebra, Suiza. Tiene a cargo el mantenimiento y administración del sistema ISAN, promoviendo la creación y funcionamiento de las agencias locales o regionales, quienes son las que asignan los códigos ISAN.

En la región, la gestión del ISAN está a cargo de ARIBSAN (Agencia Iberoamericana del registro ISAN, https://www.aribsan. $\mathrm{com} /$ ), creada y promovida por EGEDA (Entidad de Gestión de Derechos de los Productores Audiovisuales) y por SGAE (Sociedad General de Autores y Editores).

De acuerdo con sus administradores, el ISAN brinda las siguientes ventajas: ${ }^{58}$

56 Cfr. Paskin (1999). El autor desarrolla los elementos básicos que debe cumplir un identificador universal: debe ser único por objeto, de alcance internacional, neutral, persistente, numérico, incorporar un dígito de control, granular (artículos compuestos), objeto definido, capacidad incremental suficiente, asociación de diversos metadatos, vinculado a un sistema de administración, utilizable por diferentes partes interesadas.

57 Como estándar ISO, toda la propiedad intelectual de ISAN es propiedad de ISO, incluido el Registro ISAN. Así, el uso y acceso de los datos ISAN se rige por la normativa ISO que garantiza un acceso permanente a los datos bajo condiciones sin fines de lucro y no discriminatorias.

58 Cfr. International Standard Audiovisual Number (s.f.). 
1. Es un identificador único de obras audiovisuales que ayuda a la gestión de la cadena comercial (productores, distribuidores, televisoras, etc.), dando lugar a la identificación inequívoca de una obra.

2. Facilita el intercambio de información electrónica entre las diferentes bases de datos, con una mayor rapidez en la gestión y reduciendo los posibles errores de identificación.

3. Permite la catalogación y control eficaz de las obras.

4. La característica de "número de referencia único" lo convierte en un elemento fundamental para la lucha contra la piratería.

5. Es una herramienta que mejora la gestión y las actividades de la industria audiovisual mundial.

6. Facilita el registro de la obra y su explotación.

7. Mejora la gestión de los derechos de propiedad intelectual.

A los fines de la asignación del ISAN, y sin perjuicio de las definiciones legales de cada territorio, una obra audiovisual es aquella "que consiste en una secuencia de imágenes relacionadas, con o sin sonido acompañante, la cual se pretende hacer visible como una imagen en movimiento a través del uso de dispositivos, indiferente al medio de fijación inicial o subsiguiente". Esto permite que se puedan identificar programas y contenidos muy diversos, como obras publicitarias, programas informativos, deportivos, transmisiones en directo, conciertos, videoclips.

Algunas aclaraciones son importantes. El ISAN no suple al registro ante las oficinas nacionales de derecho de autor, ya que son asignados independientemente de la situación de la obra con respecto a los derechos de autor o la titularidad de la obra. Tampoco se modifica ante cambios de titularidad. Ni los números ISAN ni los otros identificadores dan cuenta de estas cesiones ni de las titularidades sobre una obra. Sin embargo, algunos registros permiten declarar el número ISAN al registrar la obra, como la US Copyright Office o la Dirección Nacional del Derecho de Autor, de Argentina. ${ }^{59}$

59 Respecto a Estados Unidos, cfr. https://www.copyright.gov/newsnet/2018/706. html. Para Argentina, Disposición 2 - E/2016 de la Dirección Nacional del Derecho de Autor, disponible en:_http://servicios.infoleg.gob.ar/infolegInternet/anexos/265000-269999/265007/norma.htm. 
El ISAN asignado a un contenido audiovisual, ya sea la obra original o una de sus versiones, persiste a lo largo de todo el ciclo de vida del contenido al que identifica. ${ }^{60}$ Una vez que una obra ha sido dada de alta en la base de datos, solo pueden incorporar información el registrante o la agencia de registro correspondiente. El código asignado puede ser utilizado por los autores, organismos de radiodifusión, las SGC, entidades financieras, productores, titulares de derechos, plataformas digitales, agregadores de contenido, entre otros.

El propósito de la base de datos ISAN es centralizar todos los números ISAN y recopilar una información mínima (por ejemplo, títulos, año, duración, plantel, etc.) necesaria para distinguir obras similares y, por lo tanto, distribuir códigos ISAN únicos. Esta información básica suele estar disponible en otras bases de datos de OA, pero, a diferencia, de ISAN, estas otras bases de datos tienen información complementaria. A modo de ejemplo, IMDb, TMDb y otros proveedores de metadatos tienen información más extensa, como sinopsis, calificaciones, listas extensas de elenco y equipo, audiencia, etc. Otras bases de datos tienen información adicional sobre los titulares de derechos y los términos contractuales, como Avails. ISAN permite almacenar los ID de dichas bases de datos, como por ejemplo el ID de IMDb o el EIDR.

De aquí que el código ISAN asignado a una obra no impide el uso de otros identificadores o la incorporación a otras bases de datos. Mediante el uso de una funcionalidad específica, es posible vincular otros identificadores, como se puede ver a continuación:

\section{Identificadores \\ vinculados e}

Valor de ID vinculado

Tipo de identifica... .

ID de Dominio

Nota

ISAN vinculado o

Añadir ISAN vinculado

Figura 10. Desplegable de identificadores asociados al ISAN (fuente: Aribsan). 


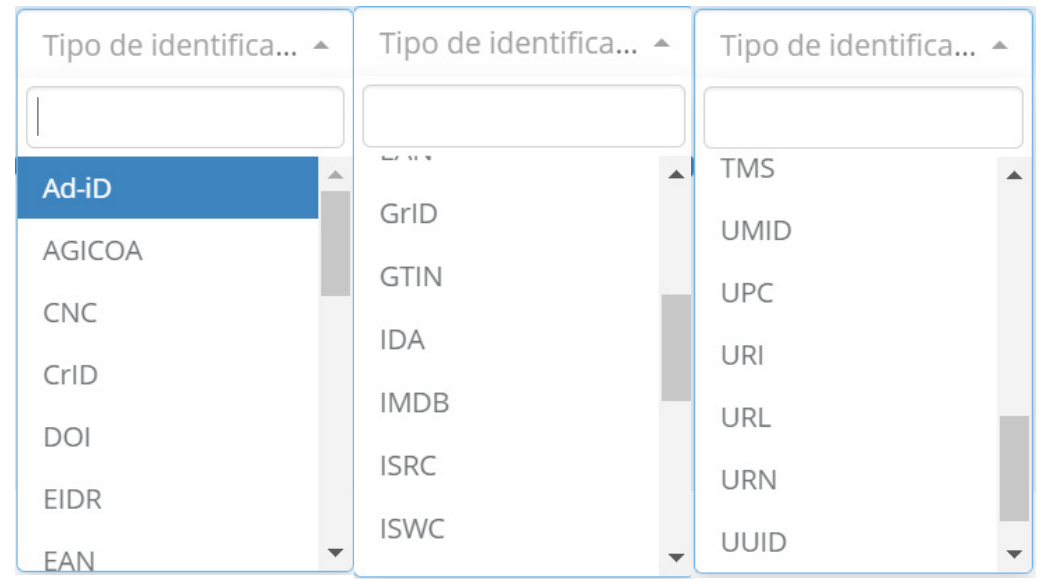

Figura 11. Desplegable de identificadores asociados al ISAN (fuente: Aribsan).

En algunos países, el ISAN es utilizado más intensamente que en otros. Las SGC de España, Francia, Italia, Suiza y Bélgica, por ejemplo, exigen ISAN para las obras cuyos derechos gestionan. La identificación de las obras es más rápida y precisa, lo que les permite a dichas SGC focalizarse en tareas de valor ańadido, como la resolución de conflictos de derechos. El ISAN también es utilizado por entes de promoción o financiamiento de la cinematografía. Es de uso obligatorio por el programa de medios de la UE, como así también por el Centre Nacional du Cinéma et de l'image Animee (CNC Francia) para toda la financiación audiovisual desde 2017. Otros países en los que resulta obligatorio el uso del ISAN son Finlandia, Países Bajos, Bélgica, Canadá (Fondo de Medios Canadienses), Australia (Screen Australia), República de Corea (Kofic), etc. Al requerir ISAN para todos los proyectos audiovisuales que se financian, se pueden identificar dichos proyectos, rastrearlos y finalmente medir la eficiencia de la política de financiamiento.

Varias plataformas digitales utilizan el ISAN: Apple, Amazon, Google Play, Microsoft, Netflix, Starz Play, Canal VoD (FR), FilmoTV (FR), OCS (FR) arte (FR / DE), Pentaflix (DE), etc. Por ejemplo, el uso del ISAN es un requisito de Apple y Amazon para la distribución de contenido en los países con regulaciones basadas en ISAN, como Suiza. ${ }^{61}$

61 ISAN es un requisito legal en Suiza desde inicios de 2017, siendo obligatorio 
Los números ISAN otorgados están disponibles gratuitamente para que cualquiera los pueda utilizar. Una plataforma digital $\mathrm{u}$ otro interesado pueden obtener el ISAN correspondiente a una OA determinada mediante búsqueda individual en la base de datos de libre acceso (http://www.isan.org/lookup/) o directamente de los titulares del contenido cuando es cargado en la plataforma. ${ }^{62}$

El ISAN de una obra normalmente es solicitado por el productor antes de la explotación o salida al mercado, lo cual facilita la fidelidad de la información. La carga se realiza mediante el Formulario de registro de obra. ${ }^{63}$ Pero también lo puede hacer el distribuidor por las versiones o cualquier otro participante, como los agregadores de contenido. Inclusive lo puede hacer una SGC en nombre de uno de sus socios. No se presentan problemas de doble solicitud, ya que los datos cargados se integran y, en caso de coincidencias, el sistema advierte sobre la posible duplicación. El número es uniforme sin importar la ventana de explotación de la obra. El ISAN puede presentar cambios en el caso de versiones, como el subtitulado y el doblado. Algunos productores o distribuidores solicitan un ISAN independiente por el soporte, como el caso de Blue-Ray, ya que incluye varios subtitulados y doblajes, además de contenidos adicionales, como el "detrás de cámara”. Estos números independientes facilitan el control de las fuentes de ingresos. También se pueden solicitar números ISAN para back stock de obras, es decir, obras producidas con anterioridad a la creación de la Agencia, así como un ISAN para obras en desarrollo, que se encuentran en las etapas tempranas de producción.

El código ISAN, cuando se representa de forma escrita, es un código alfanúmerico de 24 dígitos hexadecimales, que presenta la siguiente estructura. ${ }^{64}$

su uso para la presentación de informes ampliada según el artículo 16a de la Ordenanza sobre películas. A su vez, todas las plataformas digitales que distribuyen contenido en Suiza deben reportar su catálogo con ISAN a las autoridades suizas, a los fines estadísticos. Esto permite comprender mejor el mercado digital en Suiza y la participación de las producciones nacionales. https:// support.isan.org/hc/en-us/articles/360002396571-Using-ISAN-in-iTunes.

62 Disponible en http://www.isan.org/lookup/.

63 Disponible en https://www.aribsan.com/documentos/Formulario_de_registro_de_obras.pdf.

64 International Standard Audiovisual Number (2005). 


\section{Raíz Episodio Versión \\ ISAN $0000-0000-811 F-0000-R-0000-0000-U$}

\section{Donde:}

- Los primeros 12 dígitos representan el segmento raíz.

- Los siguientes 4 dígitos representan el episodio/parte de una obra seriada.

- Los últimos 8 dígitos representan la versión extendida.

Junto con el número se pueden obtener varias imágenes, las cuales pueden ser embebidas como XMP en el archivo digital, bajo diferentes formatos, como Windows Media, Flash, QuickTime, MPEG $2 \& 4$, Sony HDV, XDCAM, entre los principales. Esto permite el escaneo para obtener los metadatos asociados a dicho número:

\begin{tabular}{|l|l|}
\hline ISAN 0000-0001-68EC-0000-x-0000-0000-c & $\begin{array}{l}\text { Formato JPEG: resolución media, me- } \\
\text { jor para distribución electrónica e im- } \\
\text { presión. Este código de barras se utiliza } \\
\text { para visualizador web, en soporte físi- } \\
\text { co, en documentos o etiquetas. }\end{array}$ \\
\hline $\begin{array}{l}\text { Formato EPS: alta resolución, imagen } \\
\text { en blanco y negro. Este código de bar- } \\
\text { ras está adaptado para el uso en crédi- } \\
\text { tos cinematográficos (fondo negro). }\end{array}$ \\
\hline $\begin{array}{l}\text { Formato JPEG: resolución media, me- } \\
\text { jor para distribución electrónica e im- } \\
\text { presión. Se utiliza este código de barras } \\
\text { para visualizador web, en soporte físi- } \\
\text { co, en documentos o etiquetas }\end{array}$ \\
\hline
\end{tabular}

Tabla 2. Modelos de etiquetas de código QR associado al ISAN (fuente: Aribsan). 
El número ISAN, para obras en formatos digitales se integra en la obra en sí misma, de modo que pueda quedar fijado de forma permanente al contenido original de la OA para perdurar de modo indeleble a lo largo de toda su existencia. Estos formatos permiten el escaneo de una red o un servidor para detectar la presencia o el tráfico de una obra determinada. Es un instrumento que habilita el uso de robots o motores de búsqueda, para que, mediante mecanismos automatizados, verifiquen el uso de obras en las plataformas.

La base de datos de ISAN cuenta con una API que permite intercambiar información entre bases de datos. Esto es útil para contrastar una base de datos completa o un archivo particular, como por ejemplo las "parrillas" o programación de las señales de TV. También se pueden cruzar los datos de otras bases de datos para asignar el ISAN a información que carece de ese dato, como IMDb. La consulta individual es gratuita, mientras que el uso permanente requiere la firma de un convenio entre la autoridad del ISAN y el requirente.

Hay tantos procesos API que vinculan el ISAN como aplicaciones; los siguientes son los más típicos:

1. Registro ISAN: un usuario ISAN tiene datos audiovisuales, pero no el ISAN. Normalmente, un usuario agrega datos audiovisuales a una base de datos de terceros (para la gestión de derechos, ventas, festivales, distribución digital, etc.), los cuales se envían simultáneamente al registro ISAN. La API de ISAN devuelve el nuevo ISAN o el ya existente si el trabajo fue registrado previamente (por ejemplo, por un coproductor). Por ejemplo, cuando una obra con subtítulos se registra en la base de datos de subtitulados Cinando (https://cinando.com), automáticamente se asigna una nueva versión de ISAN y se agrega a esa base de datos, así como al archivo de subtítulos para asegurar una correcta identificación y recuperación (búsqueda) de los subtítulos, siempre que los festivales o las plataformas de VOD necesiten subtítulos para esa obra.

2. Búsqueda de ISAN: el usuario (o un proceso automatizado) tiene un ISAN y necesita recuperar los datos asociados a él, por ejemplo, para el enriquecimiento de datos en la base de datos, evaluación de la calidad de los datos, identificación de datos, etc. El número ISAN se envía automáticamente al registro ISAN y 
la API devuelve todos los datos asociados con dicho ISAN. Por ejemplo, cuando los propietarios de los contenidos declaran sus derechos ante AGICOA, la SGC de segundo nivel representante de los productores, el sistema IRRIS permite ingresar el ISAN en lugar de la descripción audiovisual de las obras. La API de ISAN es consultada utilizando dicho número y devuelve los datos asociados. A continuación, estos datos se añaden automáticamente a la base de datos de IRRIS, lo que hace al proceso de registro mucho más rápido para el usuario.

3. Concordancia de ISAN: el usuario necesita completar su base de datos con un ISAN existente y mantener su base de datos actualizada con los registros ISAN más recientes, especialmente cuando se agregan nuevos registros a la base de datos. Al igual que para el proceso de registro de ISAN, la información audiovisual se envía automáticamente al registro de ISAN para recuperar un ISAN existente. La API devuelve el ISAN coincidente con la información audiovisual proporcionada. Por ejemplo, Mediapress (https://www.media-press.tv), un proveedor líder de metadatos en Europa, compara periódicamente su base de datos con ISAN para entregar datos audiovisuales con códigos ISAN a sus clientes, emisoras y en particular plataformas VOD.

4. Búsqueda ISAN por criterios: el usuario necesita realizar una búsqueda en el registro ISAN en base a un criterio de búsqueda. Por lo general, la información para la consulta se toma de la base de datos de terceros, como podría ser el caso de un nombre de director y un rango de ańo; la consulta ISAN se envía automáticamente al registro ISAN y la API responde con la lista de obras que corresponde a la consulta; por ejemplo, todas las obras dirigidas por el nombre del director proporcionado en el período de años solicitado. ${ }^{65}$

A octubre de 2020, el total de la base de datos de ISAN era de aproximadamente 1350000 registros y contiene producciones de Europa (54\%), América del Norte (40\%), Asia (3\%) y Latinoamé-

65 La guía de la API de ISAN está disponible en la plataforma de ISAN: https:// support.isan.org. 
rica $(3 \%)$. Por tanto, esta última es claramente una región de potencial crecimiento para el estándar ISAN y está en proceso de implementación en partes interesadas en varios países.

A esa fecha, hay solo 11717 registros ISAN correspondientes a Argentina, Brasil, Uruguay, Perú, Ecuador y Costa Rica, distribuidos del siguiente modo:

\begin{tabular}{l|l|l|l|l|l|l}
\hline & Brasil & Peru & Uruguay & Argentina & Ecuador & $\begin{array}{l}\text { Costa } \\
\text { Rica }\end{array}$ \\
\hline $\begin{array}{l}\text { Cantidad de } \\
\text { ISAN }\end{array}$ & 2899 & 1946 & 64 & 6688 & 57 & 63 \\
\hline
\end{tabular}

Tabla 3. Registros de ISAN en los países objeto del estudio (fuente: Aribsan).

Cómo se puede observar, el uso del ISAN en los países objeto del estudio es incipiente y no se puede considerar una práctica extendida.

ISAN también tiene convenios con sociedades de autores; entre otros, las sociedades latinoamericanas de autores, guionistas y directores, reunidas en la FESAAL (Federación de Sociedades de Autores Audiovisuales Latinoamericanos, https://www.fesaal.org/) promueven y utilizan el ISAN para identificar las obras que administran.

ISAN no pretende sustituir las demás bases de datos ni reemplazar otras iniciativas, sino proporcionar una identificación estándar que mejore los sistemas existentes. En ese sentido, se espera que los ISAN concedidos se difundan en todas las bases de datos audiovisuales y sean utilizados por todas las partes interesadas de la industria, en particular por aquellos que tienen metadatos extensos. ISAN puede convertirse en la clave compartida para asociar y fusionar datos entre varias bases de datos cuando sea necesario para un propósito, aplicación o negocio específico.

\subsection{El identificador EIDR}

El EIDR (Entertainment ID Registry, https://www.eidr.org/) es un sistema de identificación universal único para las OA de la industria cinematográfica y la TV. Es el resultado de un emprendimiento de los actores más relevantes de la industria norteamericana. ${ }^{66}$ EIDR es

66 La Entertainment Identifier Registry Association (EIDR) es una asociación 
una implementación de DOI (Digital Object Identifier, Identificador de Objetos Digitales) que consiste en un enlace permanente en forma de código alfanumérico que identifica de forma única un contenido electrónico. El sistema DOI no cambia con el paso del tiempo, aunque el objeto digital sea relocalizado en otra dirección, ya que incluye la información insertada en forma de metadatos (https:// www.doi.org/). Asimismo, está regulado en la norma ISO $26324 .{ }^{67}$

El EIDR requiere un conjunto mínimo de campos de metadatos. Adicionalmente, permite la carga de información opcional, como el ISWC, ISRC o ID del cue sheet de la música del audiovisual. Al igual que el ISAN, el registro no implica asignar ninguna propiedad o derecho sobre el contenido. Cualquier miembro del EIDR puede registrar el contenido para el que se requiera una identificación mediante la interfaz web del EIDR y API específicas. Posee un mecanismo para resolver los duplicados mediante la actualización del ID preexistente. El solicitante de registro puede ser el propietario del contenido, un agregador, una empresa de posproducción o cualquier

sin fines de lucro fundada por Movielabs, CableLabs, Comcast y Rovi para dar soporte a la cadena de suministro de entretenimiento mediante la asignación de identificadores universales para una amplia variedad de objetos audiovisuales (https://www.eidr.org/). Entre las empresas que le dan soporte se encuentran Disney, YouTube, Comcast, ESPN, HBO, Lionsgate, Microsoft, Netflix, Turner, TIVO, por mencionar algunas.

67 Se asigna permanentemente un nombre DOI a un objeto para proporcionar un enlace de red persistente y resoluble con la información actual sobre ese objeto, incluido el lugar en que el objeto, o la información sobre él, puede encontrarse en internet. Si bien la información sobre un objeto puede cambiar con el tiempo, su nombre DOI no cambiará. Este puede resolverse dentro del sistema DOI a valores de uno o más tipos de datos relativos al objeto identificado por ese nombre DOI, como una dirección URL, una dirección de correo electrónico, otros identificadores y metadatos descriptivos. El sistema DOI permite la construcción de servicios y transacciones automatizadas. Las aplicaciones de este sistema incluyen, entre otras, la gestión de la localización y el acceso a la información y la documentación, la gestión de metadatos, la facilitación de transacciones electrónicas y comerciales, la identificación única y persistente de cualquier forma de datos (https://www. doi.org/doi_handbook/1_Introduction.html). El uso de los nombres DOI comenzó con la industria editorial, pero se ha extendido a otros ecosistemas digitales. Sobre los antecedentes del DOI, cfr. Paskin (2015). 
otra entidad autorizada para registrar objetos. El registro asigna el EIDR una vez que verifica la integridad de la información. También se pueden registrar objetos relacionados, como las diferentes versiones de la OA. Por ejemplo, la versión para TV abierta puede ser diferente de la estrenada en salas.

El EIDR para un objeto consiste en un prefijo de registro estándar, el sufijo único para cada obra y un dígito de control.

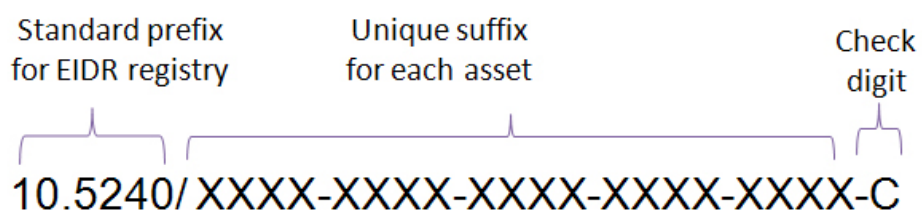

Está diseñado especialmente para permitir la automatización de procesos y la interoperabilidad entre los sistemas, principalmente del productor o titular y las plataformas de distribución, cualquiera sea su tipo, para lo cual utiliza varias API y un kit de software de desarrollo propio. Estos mecanismos permiten una mejor medición de la audiencia, la posibilidad de automatizar la entrega de contenidos, la comparación de catálogos y la elaboración de reportes sobre uso y monetización. A modo de ejemplo, es el mecanismo que utiliza Google Play para informar sobre los resultados financieros por la explotación de catálogos. ${ }^{68}$

Para esto, el EIDR es parte integrante del Marco de Distribución Digital, que incluye los términos establecidos por el productor de la OA en los EMA Avails. Se trata de un mecanismo implementado por la Entertainment Merchant's Association (antes EMA, ahora OTT.X, https://www.ottx.org/) en conjunto con MovieLabs, donde se definen los formatos para transferir la información sobre permisos de los productores a los distribuidores. Avails es un término de la industria referido a la información sobre el tiempo de inicio y finalización de una licencia, el territorio, los formatos, las platafor-

68 Cfr. http://www.eidr.org/hits-fall-eidr-identification-can-help-me-companies-boost-efficiency/. 
mas y las pautas comerciales relacionadas con la oferta de una OA. ${ }^{69}$ El consorcio recomienda utilizar el Marco para la automatización de los flujos de trabajo digitales y la eficiencia de la cadena de suministro. Está conformado por un conjunto de normas y especificaciones compatibles que cubren aspectos fundamentales de la distribución en línea, como la identificación, los metadatos, las disponibilidades, la entrega de activos y la presentación de informes. Estos estándares y tecnologías permiten la automatización, la reducción de costos y la mejora de las experiencias de los consumidores en toda la industria (MovieLabs, 2017).

Una de las grandes ventajas del uso del EIDR, de acuerdo con sus operadores, es la mejora en la medición de las audiencias, no solo en las OTT, sino también en TV. Así también se beneficia a la industria publicitaria mediante reportes más exactos y en tiempos acordes. Se pueden seguir los consumos de contenidos en smartphones, tabletas, PC, televisores conectados, etc., ya que la medición directa ofrece un mayor alcance y precisión. ${ }^{70}$ Entre otros, Business Bureau utiliza el EIDR para su sistema Content Pulse, por medio del cual se escanean diversas OTT (https://bb.vision/content-pulse/).

EIDR e ISAN pueden interactuar para facilitar la interoperabilidad de las bases de datos y los sistemas de tracking. En 2012, ambas agencias iniciaron un proceso de convergencia. ${ }^{71}$ Finalmente, en abril de 2019, pusieron en marcha un servicio de registro doble (dual) como resultado de la política de identificación de estándares audiovisuales de la Comisión Europea destinada a impulsar las oportunidades de las artes audiovisuales, el entretenimiento, la información y la gestión de archivos. Mediante el único registro dual, la OA quedará vinculada a ambos registros, lo que permitirá una fácil traducción de un sistema de identificación al otro por parte de los solicitantes y usuarios. El sistema dual también permite cargar identificaciones alternativas que se hayan asignado a la obra, como por ejemplo IMDb o TMDb, lo que también facilita el seguimiento

69 Cfr. MovieLabs (2019).

70 Entertainment Identifier Registry (2018).

71 Cfr. https://www.eidr.org/eidr-and-isan-to-provide-seamless-registration-ofcontent-ids/. 
de la OA y el uso de las identificaciones por diferentes categorías de interesados. $^{72}$

La Comisión Europea, en el marco de su política de promoción de ID de Audiovisual Estándar, ha identificado el ISAN y el EIDR como actores importantes para ayudar a los productores, distribuidores, emisores y proveedores de servicios en línea a automatizar los flujos de trabajo, reducir los costes de distribución y gestión de derechos y ampliar los beneficios de la distribución digital. Esta iniciativa facilita la adopción de identificadores estándar audiovisuales interoperables para toda la industria.

A octubre de 2020, EIDR contaba con 2290680 registros. De estos, 219097 hacen referencia a un número ISAN; 91763 registros EIDR corresponden a Latinoamérica y, de estos, 36880 son de OA producidas o adaptadas para Argentina, Brasil, Costa Rica, Ecuador, Perú y Uruguay. De estos últimos, solo 1133 informan a su vez de un número ISAN. Dichos 91763 registros vinculados a Latinoamérica se distribuyen en las siguientes categorías: 38517 corresponden a obras cinematográficas; 1 compilación; 2438 series de televisión; 1048 temporadas de televisión; 32956 episodios; 13691 ediciones (diferentes cortes de video); y 3112 manifestaciones (archivos técnicos que enlazan con ediciones particulares). Como se puede observar, los productores locales no utilizan intensivamente el EIDR, que no tiene una gran penetración en los países objeto del estudio, aunque contiene más registros locales que ISAN.

Las empresas norteamericanas con presencia en la región suelen utilizar el EIDR; entre otras, se puede mencionar DirecTV, perteneciente al conglomerado AT\&T, para sus operaciones de distribución. Debido a que EIDR ha sido adoptado por la mayoría de los estudios de Hollywood, los contenidos de Disney, Warner Bros., Sony Pictures, Paramount y NBC Universal pueden ser referenciados mediante el EIDR en la distribución de las plataformas que operan en la región. Otro tanto se puede decir de plataformas globales con presencia en Latinoamérica, como Netflix, Amazon Prime, Google Play, Microsoft Movies \& TV y Apple, ya que adoptaron el EIDR para la

72 Las buenas prácticas del registro dual pueden consultarse en: http://standard-ids.org/docs/Instructions\%20for\%20ID\%20Dual\%20Registration.pdf. 
introducción y seguimiento de contenido. También es utilizado por muchas de las plataformas de streaming con sede en Estados Unidos y con presencia en la región, como Disney+, HBO Max, Peacock, Disney Star, Hulu y Paramount+.

El uso del EIDR, en cuanto referencia inequívoca de la OA, posibilita identificar la obra en caso de infracciones. También permite distinguir versiones de la obra, de tal modo que si una versión es de uso exclusivo en un territorio, se puede vincular cada versión con sus derechos de explotación. Si bien el EIDR no fue diseñado como una herramienta forense, sin duda facilita la prueba y los mecanismos de investigación, así como la demostración del quantum del daño.

\subsection{IMDb (Internet Movie Database)}

Un recurso intensamente utilizado por la industria audiovisual es la base de datos IMDb (Internet Movie Database, www.IMDB.com). En sus inicios, en 1990, se trató de una iniciativa particular generada a partir de la lista de créditos recopilada por Col Needham, Dave Knight y Andy Krieg, miembros de un grupo de noticias sobre cine. La base se constituyó con la fusión de las listas de directores, la de actores y actrices y la de participantes fallecidos construidas por estos fanáticos del cine, con la colaboración de otros lectores del grupo. Luego, migraron a la Web, se constituyó como compañía en 1996 y a los dos ańos fue adquirida por Amazon con la intención inicial de utilizarla como plataforma de venta de CD y DVD.

Hoy día, una entrada de una OA en IMDb incluye a los productores y otras empresas asociadas con la película, la fecha de estreno por país, calificaciones de audiencia, recaudaciones de taquilla, premios obtenidos e información detallada sobre directores, guionistas, actores, banda musical, entre otra información. A junio de 2020, incluía información de 6.67 millones de producciones audiovisuales, de los cuales 4.8 millones correspondían a episodios de series televisivas.

Los datos de la IMDb están disponibles para uso personal y no comercial en distintos dataset, disponibles en línea en https://www.imdb. com/interfaces/. A modo de ejemplo, el dataset "title.basics.tsv.gz" contiene información básica de cada obra, designada bajo un título: 
- Tconst, identificador alfanumérico único del título.

- titleType, el tipo/formato correspondiente al título; por ejemplo, película, cortometraje, serie de televisión, tvepisodio, video, etc.

- primaryTitle, el título más popular o el utilizado por los productores en la publicidad en el punto de lanzamiento

- originalTitle, título original, en el idioma original.

- esAdulto, si corresponde a material para adultos.

- startYear, el año de lanzamiento de un título. En el caso de las series de televisión, es el año de inicio de la serie.

- endYear, finalización de las series de TV.

- runtimeMinutes, tiempo de ejecución primario del título, en minutos.

- géneros (string array), incluye hasta tres géneros asociados al título.

Si se desea contar con información agregada referida a los actores, guionistas y directores, se debe utilizar otro dataset, como "title. principals.tsv.gz", que bajo el mismo título de cada obra audiovisual contiene información referida a:

- tconst (cadena), identificador alfanumérico único del título.

- ordenamiento (entero), número para identificar de manera única las filas de un determinado título.

- nconst (cadena), identificador alfanumérico único del nombrel persona.

- categoría (cadena), categoría o rol que esa persona cumplía en la obra.

- trabajo (cadena), título específico del trabajo.

- caracteres (cadena), nombre del personaje interpretado.

Los datos se pueden descargar como archivos de texto plano comprimido y la información puede extraerse utilizando las herramientas de interfaz de línea de comandos que se proporcionan. También está disponible una aplicación de interfaz gráfica de usuario basada en Java que es capaz de procesar los archivos de texto plano comprimido, lo que permite una búsqueda y una visualización de la información. También se puede utilizar un paquete Python llamado IMDbPY para procesar los archivos de texto plano comprimido en varias bases de datos SQL diferentes, lo que permite un acceso más 
fácil a todo el conjunto de datos para la búsqueda o la minería de datos.

El uso de la información de cada dataset no permite alteraciones. De hecho, se indica expresamente que "no se puede utilizar la minería de datos, robots, raspado de pantallas o herramientas similares de recopilación y extracción de datos en este sitio, excepto con nuestro consentimiento expreso por escrito como se indica a continuación" (https://contribute.imdb.com/dataset). Para el uso de estos instrumentos o adaptar la base de datos para otros usos se debe solicitar permiso escrito.

La base de datos de IMDb es un recurso utilizado por prestadores de servicios de información, como por ejemplo Business Bureau (https://bb.vision/), para construir sus propias bases de datos que permiten identificar los visionados de las plataformas o también las fichas de la exhibición en salas.

\subsection{TMDb (The Movie Database)}

Una alternativa a IMDb es TMDb (https://www.themoviedb.org/). Es una plataforma construida colaborativamente e iniciada por Travis Bell en 2008 como un repositorio de los pósters de las películas. Tiene un fuerte enfoque internacional y gran amplitud de datos. Participan activamente aproximadamente 200000 miembros, ya sean individuos o empresas. Es una gran fuente de metadatos y de imágenes. También cuenta con una API de uso gratuito para usuarios individuales y paga para empresas y organizaciones. En todos los casos, se requiere hacer referencia a que TMDb es la fuente de los datos utilizados. La base de datos, a octubre de 2020, contenía información disponible de 597791 películas, 101054 series y 2200758 episodios. Parece escasa la presencia de contenidos producidos en los países objeto del presente estudio.

\subsection{TVDB}

TVDB (https://thetvdb.com/) es otra base de datos colaborativa sobre obras audiovisuales. A noviembre de 2020, contaba con 141000 películas, 115000 series y más de 4 millones de episodios de progra- 
mas televisivos, entre otros contenidos. Los usuarios son productores de contenido, distribuidores, fabricantes de dispositivos, agregadores y desarrolladores de software, entre otros. A través de una API, se pueden vincular los metadatos de TVDB para diferentes utilidades. La estructura (taxonomía) y la carga de datos son sencillas. Los metadatos se encuentran estandarizados y permiten la inclusión de identificadores universales. Parece escasa la presencia de contenidos producidos en los países objeto del presente estudio.

\subsection{La música sincronizada en el audiovisual y los cue sheet}

En cualquier obra audiovisual la música constituye un elemento relevante. Para su identificación se utiliza el llamado cue sheet, que consiste en un formato que completa el productor audiovisual para informar a las SGC autorales respecto a la música incluida en el audiovisual. Por lo general, utilizan el formato estándar que sigue las directivas de CISAC. ${ }^{73}$ Los cue sheets se utilizan en dos momentos principales: al terminarse la producción de la obra o el contenido que se trate y al momento de la distribución de los derechos recaudados.

La música sincronizada al audiovisual puede haber sido compuesta especialmente o puede consistir en grabaciones fonográficas preexistentes. En el primer supuesto, el productor audiovisual contrata la composición de música propia de esa OA o programación. En el segundo, negocia un contrato de sincronización con autores, editores y titulares del fonograma. En muchos casos se trata de una combinación de música original con preexistente. Cuando se trata de programas televisivos en vivo, no se solicita autorización para la inclusión de la música grabada, ya que se trata de un derecho de simple remuneración.

La información de la música es una parte importante de los créditos o reconocimientos, ya que si la banda musical es original y compuesta a los fines de la OA, en algunas legislaciones el compositor es cotitular en paridad de condiciones con el autor del guion, el director y el productor. ${ }^{74}$ Antes del estreno, el productor debe informar

73 Cfr. CISAC (2019).

74 Por ejemplo, Argentina, Ley 11723, artículo 20. 
a la SGC del país de lanzamiento cuál es la música incorporada. En algunos casos también debe pagar los derechos de sincronización, como el caso de SADAIC en Argentina. ${ }^{75}$ Además, en los sistemas de fomento que distribuyen subsidios u otorgan crédito financiero, hay que presentar el "libre deuda" por los pagos debidos por dicha sincronización a los fines de recibir los subsidios.

Como ya se indicó, el cue sheet es una obligación del productor que debe ser cumplida antes de enviar la OA al distribuidor digital, ya que forma parte de la cadena de derechos. Así lo establece, por ejemplo, el contrato modelo que la Independent Film \& Television Alliance (IFTA, https://ifta-online.org/) le propone a sus miembros:

Cláusula 14.1 "Cue Sheets: To the extent required and available, Licensor will supply Distributor promptly after Initial Delivery with music cue sheets listing the composer, lyricist and publisher of all music embodied in the Picture. Distributor will, as needed, promptly file with the appropriate government agency or music rights society in the Territory the music cue sheets as supplied by Licensor. ${ }^{76}$

El cue sheet indica el título de la OA o del programa, distinguien-

75 https://www.sadaic.org.ar/shared/cdrw/pdf-Aranceles\%20Cine\%20\%20022020.pdf. Los aranceles que recauda SADAIC difieren si se trata de una obra cinematográfica, programa televisivo, telefilm, obra publicitaria (uso interno o exportación), entre otros.

76 El IFTA International Standards Terms está disponible en: https://ifta-online.org/wp-content/uploads/2019/05/IFTA-International-Standard-Terms-V2018.pdf. El mismo documento, en lo que se refiere a la chain of rights, indica: "10.11. Documentation: If any Law requires Distributor to obtain a permit or clearance to exploit any Licensed Right, then Distributor will do so at its expense promptly after payment of the Guarantee. These may include any dubbing certificate, quota permit, censorship clearance, author's certificate, certificate of origin, music cue sheet, or remittance tax form. Distributor will provide Licensor on request with copies of documents indicating compliance with such Law. If this Agreement is terminated or cancelled, then upon request Distributor will take all necessary actions to ensure that any such documents are withdrawn or cancelled, failing which Distributor authorizes Licensor to do so". 
do si se trata de un episodio, capítulo o entrega semanal o diaria. También se menciona al productor, país de producción y, en caso de ser programación en vivo o de producción propia del radiodifusor, el horario de emisión y la señal. El formato prevé la inclusión del número ISAN de la OA o del programa, aunque no es obligatorio. Por cada tema sincronizado se indica el momento de inicio y final de cada uno de ellos, cualquiera sea la duración. También se indica qué tipo de uso se hace de cada tema, siendo uno de los aspectos más relevantes a declarar por los diferentes derechos que se distribuirán por cada tipo de uso. Así, se distinguen el tema de apertura, el de cierre, la música de fondo o incidental, el leit motiv y otra música destacada. A continuación, se puede ver un modelo de cue sheet: ${ }^{77}$

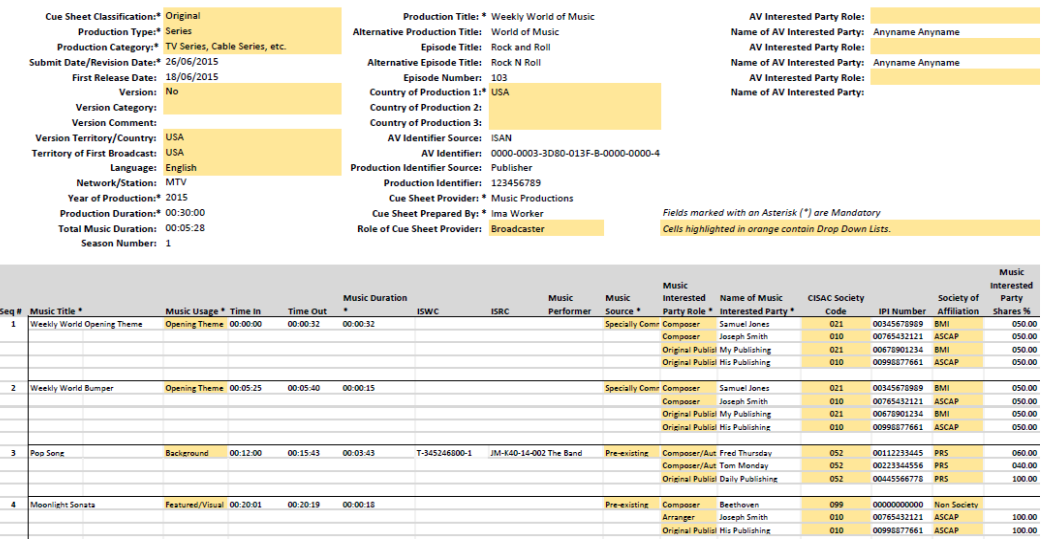

Figura 12. Modelo de cue sheet (Fuente: CISAC).

El circuito informativo de los cue sheets puede verse en el siguiente gráfico:

77 Disponible en: https://members.cisac.org/CisacPortal/consulterDocument. do? $\mathrm{id}=33455$. 


\section{Gustavo Schötz}

Estudio sobre el marco jurídico audiovisual en Latinoamérica. Parte 5: la identificación y el uso de metadatos...

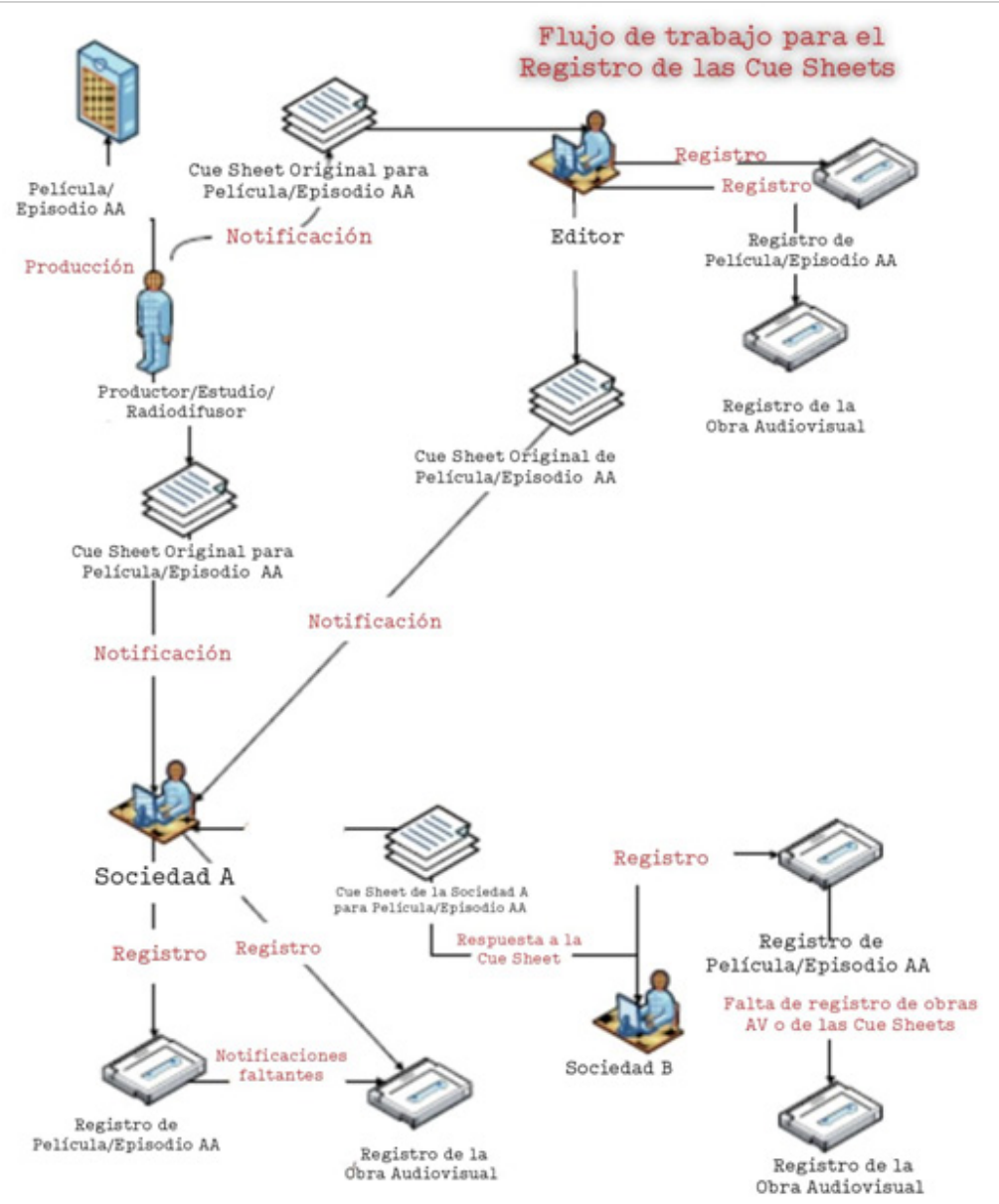

Figura 13. Flujograma de un cue sheet (Fuente: Kindermann, 2015).

Cada tema o canción se identifica con números estándares internacionales. El número ISWC (International Standard Musical Work Code o Código internacional normalizado para obras musicales) representa a los compositores y editores, y el ISRC (International Standard Recording Code o Código Estándar Internacional de Grabación) representa los datos del fonograma de la música preexistente ya grabada. Respecto a cada autor y editor, se indica el IPI correspondiente (Identificador de Partes Interesadas o Interested Party Information, en inglés), a qué sociedad están afiliados cada uno de los 
participantes y qué porcentaje de distribución de regalías le corresponde a cada uno y por cada tema. Cuando se solicita identificador uniforme para la OA, como ISAN o EIDR, los datos de la música se pueden incorporar en los metadatos de la OA referenciando el ID del cue sheet correspondiente.

El ISWC es un número de referencia único, permanente y reconocido internacionalmente para la identificación de obras musicales y constituye la implementación de la Norma ISO 15707:2001. ${ }^{78}$ Es administrado por las SGC que actúan como agencias locales o regionales, dependientes de la CISAC, que es la Autoridad de Registro. En Argentina está a cargo de SADAIC; en Brasil, de ECAD; en Costa Rica, de ACAM; en Ecuador, de SAYCE; en Perú, de APDAYC; y en Uruguay, de AGADU.

El número ISWC no hace referencia a la propiedad intelectual de la obra y permanece inalterable frente a cambios en la titularidad y sin perjuicio de los contratos de explotación sobre la obra musical. Cada versión de una obra musical tiene su propio ISWC. Cuando la música es creada especialmente para esa OA o se adapta una anterior, se debe solicitar un ISWC nuevo y específico para cada tema.

El ISWC incluye el número IPI del autor, compositor, arreglista o editor. El sistema y la base de datos IPI son administrados por la sociedad suiza de autores SUISA y forma parte del CIS (Common Information System) de la CISAC, junto con el ISWC y el ISAN (https://www.ipisystem.org/). Los autores de la OA también se pueden identificar por su propio número IPI, como los directores y guionistas; entre otros datos, informa a qué SGC pertenece cada autor. El sistema de IPI también utiliza una API que permite que los datos sean compartidos con otras bases de datos.

También se utiliza el CWR (Common Works Registration) para identificar la obra musical. Es un formato común o estándar para el registro, utilizado por los editores en su relación con las SGC. Le permite al editor registrar una obra ante la SGC del propio país para la gestión de los derechos de interpretación o los derechos mecánicos. Se identifican las partes interesadas mediante el IPI y se añade un número ISWC a la obra; luego el archivo se devuelve al

78 Cfr. https://www.iswc.org/es. 
editor. La obra totalmente identificada, incluyendo los porcentajes de derechos administrados, circula entre las filiales extranjeras de la editorial para ser enviada a otras SGC en sus respectivos territorios. El CWR proporciona un medio de rastrear la situación de registro y facilita la comunicación entre los editores y las sociedades. Incluso detalla el porcentaje específico sobre derechos de sincronización asignado a cada parte interesada. Está previsto para facilitar un flujo más preciso de datos de temas musicales entre los editores y las SGC, especialmente en cuanto al pago de regalías. ${ }^{79}$ La gestión y mantenimiento del CWR está a cargo de CISAC.

Los cue sheet son incluidos por la SGC receptora en el Audio-Visual Index (AV Index) de CISAC, que conforma un listado con la información sobre las OA y qué SGC dispone del cue sheet correspondiente a esa OA. Cada SGC pone a disposición los cue sheet para que sean utilizados por las sociedades homólogas de otros territorios cuando un usuario informa que cierta OA fue comunicada al público o utilizada de otro modo y se han recibido pagos por ese uso y debe efectuarse la distribución correspondiente. Se trata propiamente de un índice que identifica qué SGC dispone del cue sheet de cierta y determinada OA; no es en sí misma una base de datos de obras musicales ni de cue sheet. De aquí que resulte inevitable que la SGC que debe efectuar la distribución por primera vez respecto a esa OA deba solicitar el respectivo cue sheet a la sociedad originaria. ${ }^{80}$ Identificando la OA se vincula la música incluida para liquidar los derechos correspondientes.

Como se indicó, para la música preexistente grabada en fonogramas, el identificador universal es el ISRC. Usualmente es asignado por la compañía discográfica, pero también se advierte que a veces lo solicita el mismo intérprete o terceros, como los agregadores. Los cue sheet prevén su incorporación cuando la música sincronizada al audiovisual es un fonograma comercial. El derecho de remuneración de los autores, productores fonográficos y de los artistas musi-

79 Para más detalle del funcionamiento y elementos que componen el CWR, cfr. Zetterlund (2011).

80 Cfr. CISAC, IDA and AV Indexes, https://www.cisac.org/What-We-Do/Information-Services/IDA-and-AV-Indexes. 
cales por comunicación pública del audiovisual al que se incorpora el fonograma no tiene un tratamiento uniforme en todos los países. Así, por ejemplo, para Argentina, en razón de la interpretación jurisprudencial de la Corte Suprema de Justicia de la Nación, no se gestiona la recaudación por exhibición en salas, salvo que hubiera difusión del fonograma antes de comenzar la película, en el intervalo o al finalizar. ${ }^{81}$ Por el contrario, sí se recauda por la música grabada radiodifundida en televisión. Sin embargo, en las legislaciones de Ecuador y Perú, antes de que ratificaran el Tratado de Beijing, está reconocido a favor de los artistas (incluidos los músicos) un derecho de remuneración por la comunicación pública de grabaciones audiovisuales. Estas diferencias plantean la necesidad de identificar la comunicación pública reconocida de país a país, ya que aun cuando en un territorio no sea reconocido el derecho, por aplicación del trato nacional es necesario identificar la música sincronizada en todos los países en los que sí es reconocido.

Respecto a la música compuesta a los fines del audiovisual, su tratamiento por parte de las plataformas depende del modelo de negocio de cada una de ellas y del tipo de derechos que tengan sobre cada obra audiovisual y musical. Cuando la OTT es la titular de los contenidos por ser la productora, las composiciones musicales son hechas generalmente bajo contrato de cesión de derechos y resultan en titularidad de la plataforma-productora. Sobre esa música no se generan pagos por la explotación de las obras audiovisuales, salvo que la legislación local haya reservado un derecho de remuneración expreso a favor de los compositores. Por el contrario, si la plataforma no es titular sino licenciataria de la obra, los derechos son o bien de los compositores o bien del productor de la OA licenciada. En estos casos, los cue sheet son utilizados para distribuir las sumas que la plataforma debe pagar por esa música incorporada.

A modo de ejemplo, en Perú, APDAYC, la sociedad de autores y compositores musicales, recibe la información y los pagos sobre la música de las OA visionadas de Netflix. Luego, para la distribución, debe realizar una tarea de asignación de esas sumas a cada titular, cualquiera sea el territorio y la SGC que lo represente. A estos fines,

81 SADAIC c. Andesmar S.A., CSJN, S. 129. XXXVII, 23/03/2004. 
ha contratado con BackOffice (http://www.backoffice-ms.com/) el servicio de reporte detallado de distribución. BackOffice es una empresa que elabora informes de recaudación y distribución para la gestión de derechos de autor de obras musicales. Para conformar su base de datos, recibe la información básica de las SGC representativas de compositores y editores con las que trabaja, correspondientes a más de 70 países. Han adoptado los estándares CWR e ISWC para identificar las obras. La base de datos está unificada multiterritorialmente. Si bien los principales servicios se orientan a las liquidaciones de las ventas digitales de música, ahora también brindan servicios por la música incorporada a los audiovisuales que son puestas a disposición en las plataformas de VOD. A partir de los reportes nacionales que presentan plataformas como Netflix, y mediante el recurso a los cue sheets, están en condiciones de elaborar informes detallados de distribución de derechos

Las SGC que representan a los intérpretes y a los productores fonográficos no utilizan el cue sheet para la distribución, ya que les es suficiente conocer el ISRC de cada fonograma comunicado públicamente, los cuales son identificados mediante los sistemas de huella digital. Las huellas digitales también se utilizan para automatizar la conformación de los cue sheet. Los algoritmos de identificación se aplican para determinar el inicio y final de cada canción de acuerdo con las escenas de la obra audiovisual. Empresas como BMAT, Monitec (https://www.monitec.com/index.php) y Monitor Latino (http://monitorlatino.com/) prestan este servicio a los productores audiovisuales y a los organismos de radiodifusión.

\subsection{IDA}

La IDA (International Documentation on Audiovisual works, https://www.ida-net.org/) es una base de datos internacional en línea que contiene información sobre producciones audiovisuales como películas, programas de televisión, documentales, series y obras audiovisuales cortas. Es una herramienta proporcionada por CISAC y está disponible para sus miembros, es decir, las SGC. Se trata de un repertorio global que gestiona producciones originales, versiones $\mathrm{y}$ adaptaciones en otros idiomas y formatos. El registro de cada obra 
contiene información básica referida al título en sus diversos idiomas, subtítulos, productores, año y lugar de producción, idiomas en los que está disponible, titulares de derechos, ISAN, plataformas de explotación y un código único de la IDA.

El código de IDA es utilizado por las SGC para identificar las OA y a los titulares de derechos, de tal modo que resulta posible distribuir las recaudaciones con las otras SGC homólogas, ya sea del mismo o diferentes países. Cada SGC local transferirá las recaudaciones a sus autores socios o representados. El código único de la IDA también sirve para que las SGC intercambien información sobre las OA, ya que forma parte de las Reglas Profesionales de la CISAC y de las Resoluciones Vinculantes para las sociedades audiovisuales, normas que tienen como objetivo mejorar la transparencia y la calidad del servicio para todos sus miembros. ${ }^{82}$ Dichas Reglas indican, entre otras cosas, que cada SGC debe recopilar puntualmente información pertinente sobre las obras explotadas por sus titulares (\#15.d) y mantener una documentación precisa y actualizada de su repertorio (\#17.a).

De acuerdo con CISAC, las funcionalidades y ventajas de IDA son las siguientes:

- Centraliza y proporciona información autorizada sobre obras audiovisuales y sus titulares de derechos a nivel internacional.

- Facilita la identificación y el intercambio de documentación sobre obras audiovisuales y sus titulares de derechos entre SGC.

- Acelera la transferencia de regalías entre sociedades audiovisuales.

- Permite la consulta y el registro de información sobre OA, así como de sus partes interesadas.

82 De acuerdo con CISAC, las Reglas Profesionales son un conjunto de principios obligatorios establecidos por la organización para garantizar que los miembros ejerzan sus actividades con arreglo a las mejores prácticas profesionales, de gobierno, administrativas, financieras y técnicas. Entraron en vigencia en 2009 para las sociedades del repertorio dramático, literario y audiovisual y la última versión fue adoptada en 2019. Disponible en https://es.cisac. org/Nuestras-Actividades/Gobierno/Reglas-Profesionales\#: : :text=Las\%20 Reglas\%20Profesionales\%20son\%20un,\%2C\%20administrativas\%2C\%20 financieras $\% 20 \mathrm{y} \% 20 \mathrm{t} \% \mathrm{C} 3 \%$ A9 cnicas. 
- Habilita a la importación y exportación de archivos, así como su tratamiento por lotes, utilizando servicios web.

IDA forma parte integral del CIS-net (Common Information System), de la CISAC. ${ }^{83}$

\subsection{VRDB}

SCAPR es la asociación internacional que reúne a las SGC de intérpretes audiovisuales. Tiene sede en Bruselas, Bélgica, y la conforman 56 SGC de 42 países. Entre ellas, las correspondientes a Brasil, ABRAMUS, SOCINPRO y UBC, que representan a intérpretes musicales. La gestión de la información y las bases de datos sobre los derechos administrados por cada sociedad local son aspectos fundamentales y constituyen su razón de ser.

De acuerdo con el artículo 4 de los Estatutos de SCARP, para ser miembro ordinario, una SGC tiene que haber establecido una base de datos con información de registro y sobre las remuneraciones que administran, tanto en relación con los titulares de derechos nacionales como extranjeros. Asimismo, los miembros deben utilizar un número de identificación único y reconocido de los artistas intérpretes o ejecutantes internacionales, así como participar de las bases de datos IPD y VRDB (Virtual Recording Data Base). ${ }^{84}$

En el caso de la VRDB, la base de datos tiene por objetivo facilitar el desarrollo global de la reciprocidad. Las sociedades miembros

83 CIS-Net es una red de bases de datos que depende de las Normas del CIS. Cada base de datos constituye un nodo dentro de la red global. Más información sobre CIS-net, cfr. https://es.cisac.org/Nuestras-Actividades/Servicios-de-Informacion/CIS-Net.

84 De acuerdo con lo establecido por el artículo 9 de los Estatutos, SCAPR ha constituido un Comité de Bases de Datos y Sistemas, el cual tiene a cargo el desarrollo y la gestión de las bases de datos ya mencionadas. Estas son plataformas técnicas a disposición de las SGC para el procesamiento y el intercambio de datos con respecto a los artistas intérpretes o ejecutantes y a las grabaciones de los conciertos y otros espectáculos registrados. Es obligación de cada miembro ordinario participar de dichas bases de datos, que si bien son propiedad de SCARP, cada SGC sigue siendo la propietaria y quien administra su propia información. 
recaudan regalías por el uso de grabaciones de sonido y obras audiovisuales en sus respectivos territorios. Luego, esas regalías se distribuyen a los artistas intérpretes o ejecutantes (y, en algún caso, a los productores) a nivel nacional por cada sociedad miembro, y en el plano internacional mediante acuerdos de reciprocidad. El sistema de la VRDB proporciona un mecanismo centralizado que les permite a las SGC identificar de manera más eficiente y precisa las grabaciones y obras e intercambiar la información de los artistas intérpretes o ejecutantes necesaria para realizar adecuadamente las distribuciones a nivel local. De este modo, la VRDB maximiza el flujo de regalías que se intercambian entre las sociedades miembros del SCAPR.

De acuerdo con la misma SCARP, algunos de los beneficios que obtienen los miembros que utilizan la VRDB son:

- Reducir la carga de trabajo mediante el aumento de la automatización.

- Obtener e intercambiar información de modo anticipado.

- Estandarizar los procesos y acordar un formato común para intercambiar información.

- Aumentar la transparencia, las participaciones y el intercambio de ingresos transfronterizos.

- Reducir los costos para los titulares de derechos.

Los elementos esenciales del VRDB son los siguientes:

- Es un medio común de agrupar grabaciones o trabajos y consolida una sola versión de cada OA y fonogramas, ya que de otro modo podrían estar duplicados en cada país.

- Es una fuente central de datos de repertorio accesible, de modo que el repertorio mundial se almacenará y mantendrá de forma centralizada en un lugar que permita presentar, consultar, procesar y extraer datos en beneficio de todos los miembros.

- Constituye una solución técnica escalable que admite un creciente volumen de datos y requisitos de procesamiento a nivel mundial, facilitando los pagos transfronterizos.

- Permite el uso común de algoritmos de coincidencia y validación y asegura que todos los participantes cuenten con la información de uso y listados uniformes, obteniendo una similitud de resultados. 
- Crea un repositorio central para la información de uso y listados de reproducción

Los VRDB son solicitados por las entidades de gestión colectiva locales y solo puede ser modificado por esa u otra SGC que tenga facultades suficientes. Por tratarse de una base de datos propiedad de las entidades, solo estas la pueden consultar, aunque permite la interoperabilidad con otras bases de datos, ya que admite la incorporación de otros identificadores universales, como ISAN, EIDR o ISRC, siendo estos campos voluntarios. A enero de 2021, había 292536 registros audiovisuales en VRDB.

En el caso del IPD (International Performers Database), tiene por objetivo identificar a los artistas intérpretes o ejecutantes individuales de grabaciones sonoras y obras audiovisuales y a qué SGC pertenecen, así como el tipo de mandato que les han otorgado para recaudar en su nombre. El punto de partida para identificar a cada artista intérprete o ejecutante procede del mandato legal que el artista intérprete o ejecutante ha asignado a sus SGC. Se asigna un identificador único por artista intérprete o ejecutante, lo que permite que todas las SGC miembros de SCAPR pueden intercambiar información entre ellas de manera fiable, simplificando y mejorando los algoritmos de comparación y la identificación adecuada del titular de los derechos, así como en otras bases de datos y sistemas de información vinculados a la IPD. A enero de 2021, había 1052845 intérpretes identificados con su propio IPD, entre musicales y audiovisuales.

Estos son los registros correspondientes a los países objeto del presente Proyecto: ${ }^{85}$

85 En el caso de los intérpretes, la gran mayoría de los registros corresponden a intérpretes musicales. 


\begin{tabular}{|l|c|c|}
\hline $\begin{array}{c}\text { Pais de producción / } \\
\text { nacionalidad }\end{array}$ & OA en VRDB & $\begin{array}{c}\text { Intérpretes IPD } \\
\text { (audiovisuales y } \\
\text { musicales) }\end{array}$ \\
\hline Argentina & 36 & 2243 \\
\hline Brasil & 1 & 80978 \\
\hline Peru & 0 & 1069 \\
\hline Uruguay & 0 & 178 \\
\hline Ecuador & 0 & 131 \\
\hline Costa Rica & 0 & 52 \\
\hline
\end{tabular}

Tabla 4. Base de datos de intérpretes de los países objeto de estudio (fuente: SCAPR).

\section{La información del repertorio de las SGC}

En la Parte 2 del estudio sobre el Marco Jurídico se estableció cuáles de los derechos sobre la OA se gestionan colectivamente. En esos casos, se trate de derechos de productores y otros titulares o de derechos conexos de intérpretes y productores fonográficos, las entidades representativas requieren sistemas informáticos y bases de datos que permitan identificar sus repertorios y los usos de las obras o derechos que representan. Como ya se indicó, en los supuestos de gestión obligatoria o licencia extendida, y en menor medida para la presunción de representación, la necesidad de informar a los usuarios sobre cómo se conforma ese repertorio es menor. Por el contrario, si la representación es individual, podría requerirse una demostración respecto a cuáles son las obras por las que se requieren pagos. Sin embargo, la identificación precisa de las obras utilizadas es imperiosa a los fines de la distribución de las sumas recaudadas.

Para las OA, el principio general es que la puesta a disposición que realizan las OTT es un derecho de gestión individual a cargo del productor, aunque algunos derechos se pueden delegar mediante representación para que se gestionen colectivamente. Para los demás titulares, todos los derechos son de gestión colectiva, ya sean exclusivos o de simple remuneración.

\subsection{Productores audiovisuales}

En algunos de los países objeto de este estudio hay entidades de ges- 
tión colectiva constituidas y activas en representación de los productores audiovisuales. En Ecuador, EGEDA Ecuador (https://www. egeda.ec/); en Perú, EGEDA Perú (https://www.egeda.com.pe/); en Uruguay, EGEDA Uruguay (https://www.egeda.org.uy/). En esos tres países, los productores audiovisuales están representados para la gestión colectiva del derecho de retransmisión de las OA cuando los cableoperadores retransmiten las señales abiertas de TV. EGEDA también recauda derechos por la comunicación pública que realizan establecimientos comerciales de las señales de TV abierta y de cable o satélite que incluyan $\mathrm{OA}$ (hoteles, restaurantes, clínicas, etc.). ${ }^{86}$

En el caso de la recaudación por las OA incluidas en las señales retransmitidas por los cableoperadores, la tarifa se calcula sobre la cantidad de abonados. No se diferencia el tipo de contenidos, aunque hay un cálculo implícito respecto a cuales de esos contenidos incluyen obras por las que se debe remunerar. Esto se debe a que una parte importante de los programas de las señales son contenidos de otro tipo (noticias, deportes, etc.). Las SGC no efectúan una recaudación diferenciada o adicional si la señal de cable tiene servicio de plataforma de TVEverywhere. Se supone que se trata de un servicio adicional que recibe el abonado y por el que paga una suscripción mayor, la cual queda también alcanzada en la tarifa general. En cuanto a la comunicación pública hecha por establecimientos comerciales, las tarifas son planas por criterios de ocupación, bocas de expendio y superficie de los locales, entre otros; tampoco se requiere identificar los contenidos que se comunican en cada caso.

Para la distribución es necesario identificar qué OA incluye cada señal, ya sea de aire o cerrada, dependiendo del caso. A su vez, es necesario contar con un criterio de audiencia que determine el alcance de cada una. Las obras incluidas en cada señal son identificadas mediante planillas o reportes elaborados por terceros, que informan las grillas de programación de cada canal y en cada país. En el caso de EGEDA, en

86 A modo de ejemplo, esta es la licencia y las tarifas por comunicación pública de OA en casas de electrodomésticos en Uruguay: https://eu1.documents. adobe.com/public/esignWidget? wid=CBFCIBAA3AAABLblqZhCEPs _1HnShMflYbSfbViOPgH4reklRzJMiWTh-8mCKm1EwDhYynu9ixnEiE5JEPkA*. 
la actualidad los reportes los efectúa BMat (https://www.bmat.com/ $\mathrm{es} / \mathrm{cmos} /$ ). Adicionalmente, para aplicar un coeficiente de audiencia sobre las obras identificadas, se cruza la información con reportes de agencias como IBOPE, BB, Nielsen o KantarMedia.

Los repertorios de las SGC de productores de estos países se conforman mediante el alta que hace el productor de sus obras, junto con los repertorios extranjeros de sociedades homólogas con las que hay convenio de reciprocidad. EGEDA está favoreciendo e incentivando que los productores soliciten el ISAN de cada obra. Al no ser una exigencia legal, se trata de una tarea de convencimiento y difusión de las ventajas que tiene poder identificar las obras, no solo para la recaudación en el propio territorio, sino para la identificación de esas obras cuando son utilizadas en el extranjero.

A esto se suma el esfuerzo de EGEDA para combatir la piratería digital y para facilitar la monetización de contenidos en plataformas OTT, como por ejemplo a través del servicio de Content ID de YouTube. Estos últimos servicios son brindados a los socios mediante autorizaciones individuales y requieren mayor precisión en la identificación de las obras gestionadas. ${ }^{87}$

\subsection{Directores}

Las sociedades de gestión colectiva de los derechos de los directores tienen su propio sistema informativo, el cual se solapa o complementa con los correspondientes a las entidades representativas de otros titulares. En los países objeto de este informe, estas sociedades son:

- Argentina, Directores Argentinos Cinematográficos (DAC, http://dac.org.ar/es/).

- Brasil, Diretores Brasileiros do Cinema e do Audiovisual (DBCA, https://diretoresbrasil.org/es/).

- Ecuador, Sociedad de Gestión de Artistas y Autores Audiovisuales del Ecuador, UNIARTE, (https://www.uniarte-ec.org/).

- Uruguay, Asociación General de Autores del Uruguay (AGADU, https://www.agadu.org/index.php).

87 Cfr. https://www.egeda.com/documentos/Youtube_Folleto_2013.pdf. 
DAC, DBCA y AGADU forman parte de la Alianza de Directores Audiovisuales Latinoamericanos (ADAL, http://www.directoreslatinoamerica.org/es/) y de la Federación de Sociedades de Autores Audiovisuales Latinoamericanos (FESAAL, https://www.fesaal. org/). En Costa Rica y Perú, por el momento no hay entidades que gestionen los derechos de los directores audiovisuales.

Estas sociedades gestionan el derecho a percibir una remuneración por la comunicación pública. En Ecuador, también por la exhibición; sin embargo, en ese país los directores no tienen reconocido el derecho de puesta a disposición. A la fecha, en ninguno de los países se han recaudado derechos por puesta a disposición en plataformas de VOD a favor de los directores.

A los fines de la integración del repertorio, cada director debe declarar sus obras ante su respectiva sociedad, ya que, de lo contrario, no podrá participar de la distribución de la recaudación, ya sea de la gestionada localmente o de las remesas recibidas por reciprocidad del extranjero. Previo al registro, deben firmar el contrato de representación respectivo. El alta de la obra se realiza mediante declaración individual, a través de un formulario digital que se puede completar en línea. En el caso de AGADU es un formulario genérico para todo tipo de obras denominado "Declaración y registro de obra de gran derecho", donde se indica el título, el género y la fecha de estreno. En los formularios de DAC y DBCA, los datos son más específicos de una obra audiovisual, incluyendo la posibilidad de declarar el ISAN de cada obra. En ningún caso es necesario entregar una copia completa de la obra. Estos son los datos exigidos por la DAC: 


\section{Revista Iberoamericana de la Propiedad Intelectual}

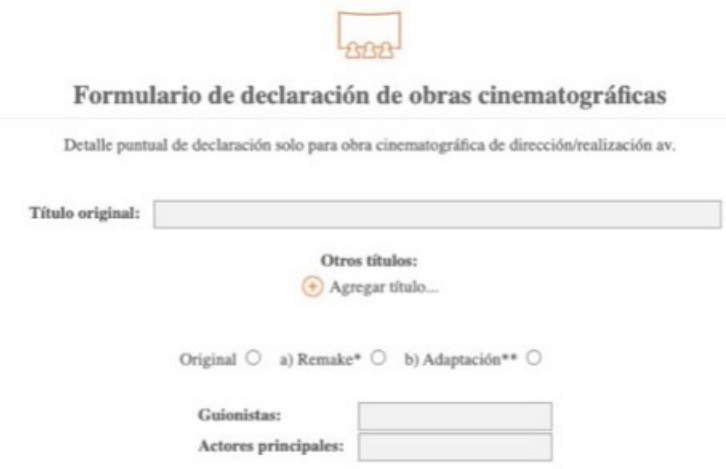

PROPORCIÓN DE REPARTO DE DERECHOS DIRECCIÓN/REALIZACIÓN
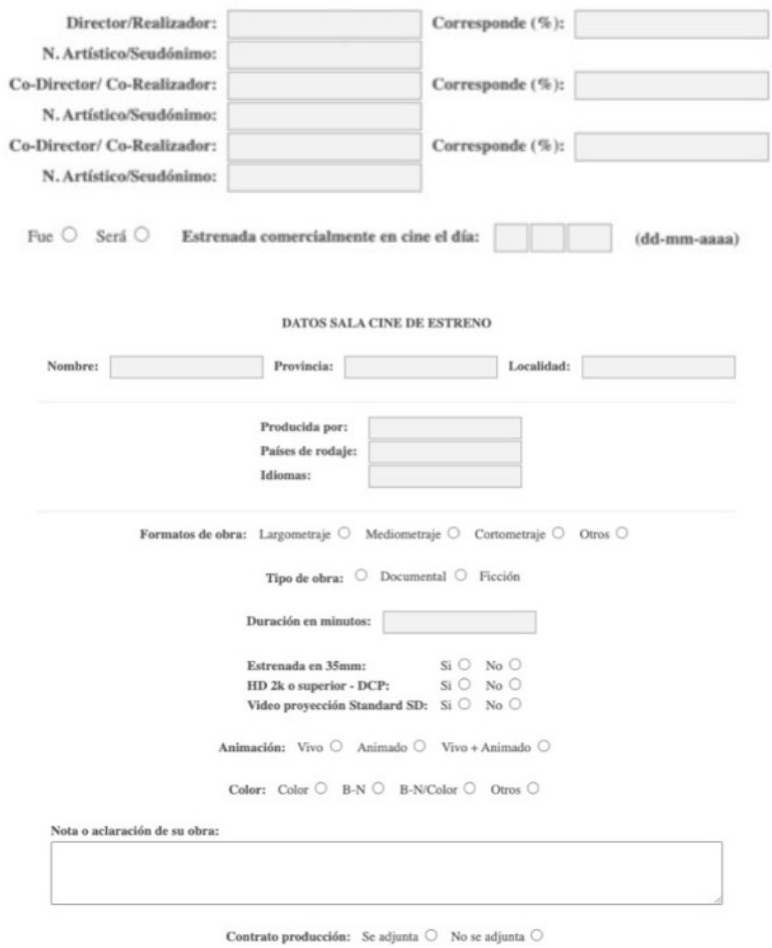

Figura 14. Formulario de declaración de OA (fuente: AGADU).

En la actualidad, a los fines de la distribución, los reportes de la grilla de programación y de rating de las señales se cruzan con las obras identificadas por su título. 


\subsection{Guionistas}

En los países objeto de este estudio, a la fecha, se han recaudado derechos de los guionistas por comunicación pública de obras audiovisuales en los siguientes países:

- Argentina, Sociedad General de Autores de la Argentina (ARGENTORES, https://argentores.org.ar/).

- Ecuador, Sociedad de Gestión de Artistas y Autores Audiovisuales del Ecuador (UNIARTE, https://www.uniarte-ec.org/).

- Uruguay, Asociación General de Autores del Uruguay (AGADU, https://www.agadu.org/index.php).

Dichas entidades recaudan derechos en TV abierta y cerrada (cable y satélite). ARGENTORES, a su vez recauda, en plataformas digitales de VOD. Su práctica respecto a la gestión de derechos en las plataformas audiovisuales es la más actualizada de la región. Cuenta con un tarifario que establece los aranceles para video on demand, fijado en un 3\% de lo cobrado en casos de TVOD, un 3\% sobre los suscriptores de SVOD, un 3\% sobre la publicidad recaudada en AVOD y un valor fijo por VOD gratuito sin publicidad. ${ }^{88}$

El repertorio administrado por ARGENTORES es universal, por cuanto su régimen legal le otorga representación respecto a

los creadores nacionales y extranjeros de obras literarias, dramáticas, dramático-musicales, cinematográficas, televisivas, radiofónicas, coreográficas, pantomímicas, periodísticas, de entretenimientos, los libretos para la continuidad de espectáculos, se encuentren escritas o difundidas por radiofonía, cinematografía o televisión, o se fijen sobre un soporte material capaz de registrar sonidos e imágenes o imagen y sonido, (artículo 1, Ley 20115)

Con respecto a sus socios, propone un modelo de contrato entre productor y guionista del contenido o programa que será puesto a disposición mediante plataformas de internet.

88 Cfr. "Régimen autoral y licencia para el uso del repertorio de Argentores en Video On Demand-Video a la Carta”, https://argentores.org.ar/nuevas-tecnologias/aranceles-nuevastecnologias/. 
También representa a "las sociedades autorales extranjeras, con las cuales se encuentra vinculada mediante convenios de asistencia y representación recíproca, y única administradora de las obras mencionadas y perceptora de las sumas que devengue la utilización de los repertorios autorales indicados". La licencia a la que se refiere el tarifario es una autorización no exclusiva brindada al responsable de la administración de los contenidos (plataforma) con domicilio legal en territorio de la República Argentina para el uso lícito de las Obras del Repertorio de ARGENTORES, exclusivamente para video On Demand-Video a la Carta y similares, de acuerdo con la modalidad de puesta a disposición de los usuarios las obras del repertorio de ARGENTORES, entendiéndose como tal aquella que le permite al público elegir la obra audiovisual y el momento de su recepción. Como se puede observar, es determinante la interactividad del usuario.

Uno de los requisitos de la licencia de ARGENTORES es que la plataforma incorpore antes del inicio de la actividad un "sistema estándar de monitoreo con acceso sin restricciones (...) a fin de que se consigne la Declaración Jurada de las obras disponibles y las obras a las que acceden los usuarios" de la plataforma (\#V.b). Luego, en el \#VIII, se indican los requisitos de la información que la plataforma debe brindar mensualmente. Todas las obras utilizadas por la plataforma deben se comunicadas a ARGENTORES en carácter de declaración jurada de acuerdo con el formato que ARGENTORES establezca, el que debe incluir los ingresos obtenidos por los servicios licenciados y generados en el período y las transacciones efectuadas por VOD. El detalle incluirá: 1) el total de obras puestas a disposición; 2) el total de obras a las que han accedido los usuarios (transacciones); 3) el título completo de la obra; 4) los nombres de los autores de cada obra utilizada; 5) el total mensual de ingresos por este concepto; 6) el total de suscriptores del período; 7) los ingresos por abonados del período, si los hubiese.

En el \#X, la licencia también incluye la facultad de ARGENTORES para realizar los controles y verificaciones necesarias para auditar la veracidad e integridad de las declaraciones juradas entregadas por las plataformas, las que se obligan a brindar toda la colaboración necesaria para dichos controles. Incluso, incluye una obligación de 
la plataforma de hacerse cargo del costo de los controles si se advirtieran diferencias superiores al $10 \%$.

En la práctica, el formato y contenidos de los reportes es acordada entre ARGENTORES y cada plataforma. El área de Sistemas de la SGC decodifica los reportes para individualizar las obras utilizadas. Dichos reportes no suelen incluir identificadores universales como ISAN, ya que pocas obras han incorporado ese código. ARGENTORES también utiliza servicios externos de auditoría para individualizar las obras, como los prestados por Business Bureau.

\subsection{Intérpretes}

En lo que se refiere a los países objeto de este estudio, las SGC que recaudan derechos por la comunicación pública o puesta a disposición de las interpretaciones audiovisuales son las siguientes:

- Argentina, Sociedad Argentina de Gestión de Actores e Intérpretes (SAGAI, https://www.sagai.org/).

- Brasil, InterArtis Brasil (https://www.interartis.org.br/), que cuenta con autorización de recaudación, pero esta no se ha hecho efectiva hasta el momento. Sin embargo, distribuye las recaudaciones efectuadas por entidades extranjeras con las que tiene convenio de reciprocidad.

- Ecuador, Sociedad de Gestión de Artistas y Autores Audiovisuales del Ecuador (UNIARTE, https://www.uniarte-ec.org/).

- Perú, Inter Artis Perú Sociedad de Artistas del Audiovisual (IAP, https://interartisperu.org/).

- Uruguay, Sociedad Uruguaya de Gestión de Actores Intérpretes (SUGAI, https://sugai.org.uy/).

Ninguna de ellas es miembro actualmente de SCAPR, debido a que son de creación reciente y su actividad recaudatoria es incipiente. ${ }^{89}$ Estas entidades recaudan por las exhibiciones en salas, emisiones de TV abierta y las de cableoperadores, además de las comunicaciones

89 De acuerdo con lo consultado con las entidades, las obligaciones que SCAPR les impone a sus miembros son difíciles de cumplir para SGC con poco nivel de desarrollo, salvo el caso de SAGAI. 
públicas en locales comerciales. Ninguna hasta el momento está recaudando por la puesta a disposición que se realiza en plataformas OTT. En el caso de Argentina, está abierta una instancia judicial. ${ }^{90}$ Perú ratificó recientemente el Tratado de Beijing, optando por el derecho de remuneración para la comunicación pública; respecto a la puesta a disposición, está pendiente una legislación específica, en base a la cual se espera que IAP pueda contar en el corto plazo con los mecanismos de recaudación en plataformas de VOD.

Para conformar el repertorio, las entidades les solicitan a socios y representados que den de alta las obras en las que participaron. Los datos se complementan con los repertorios informados por las sociedades con quienes hay convenios de representación recíproca. No se utilizan identificadores universales. A continuación, se puede ver un modelo de alta de obra:

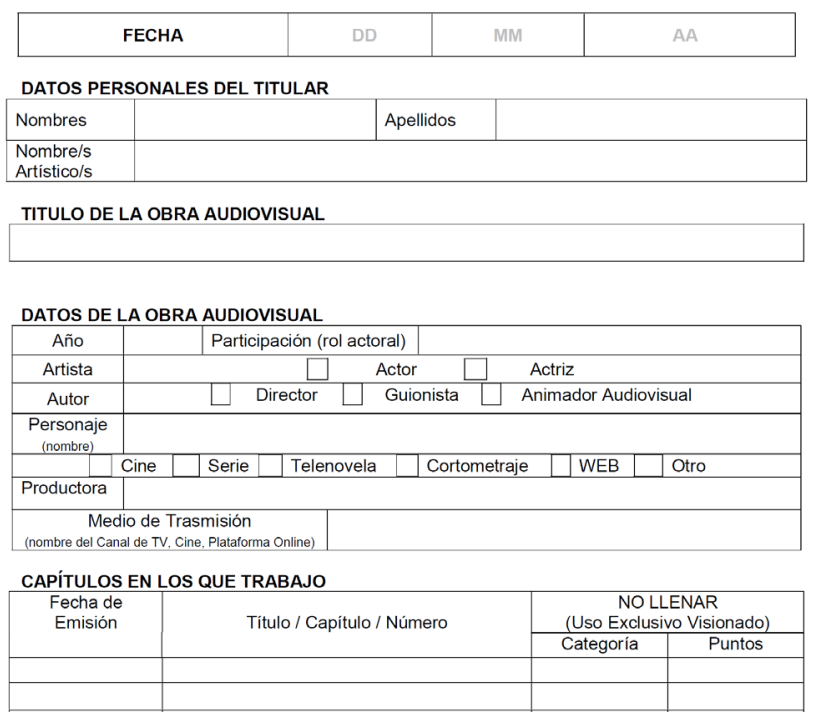

Figura 15. Formulario para declaración de interpretaciones (fuente: UNIARTE).

90 Cfr. notas de prensa: https://www.iprofesional.com/actualidad/289934-los-actores-argentinos-avanzan-con-la-demanda-contra-youtube y https://www.lanacion.com.ar/cultura/la-sagai-le-hace-juicio-youtube-derechos-nid2237013/. 


\section{Gustavo Schötz}

Estudio sobre el marco jurídico audiovisual en Latinoamérica. Parte 5: la identificación y el uso de metadatos...

Como se puede observar, en el caso de UNIARTE es un mismo formulario para autores e intérpretes, ya que es el único caso entre los países objeto del estudio que una misma entidad representa a ambas categorías de titulares.

Para la distribución de las recaudaciones, la información del repertorio se confronta con la lista de obras emitidas, identificadas por títulos y de acuerdo con información propia y reportes de agencias de medición de audiencia, a las que luego se asignan códigos internos, por obra y por episodio. Aquí algunos ejemplos:

\begin{tabular}{|c|c|c|c|c|c|}
\hline \multirow{2}{*}{$\begin{array}{l}\text { SEGUNDO } \\
\text { TRIMESTRE } \\
\text { TíruLo }\end{array}$} & \multicolumn{4}{|c|}{$\begin{array}{c}\text { OB R A S } \\
\text { L I Q U I D A D A S }\end{array}$} & \multirow[t]{2}{*}{$\begin{array}{l}\text { SAGAI } \\
2020\end{array}$} \\
\hline & TEMP. & \#CAP. & NOMBRE CAPITULO & ANOO & \\
\hline DonGab Y Su Pandlia & & & 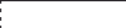 & 2011 & NDono Mas \\
\hline 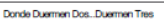 & & & & 1979 & Erique Cation Statubery \\
\hline Dona Deperisto Y Eartibuos & & & 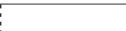 & 2019 & Gexprina Datarooses \\
\hline 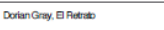 & & & & 2013 & 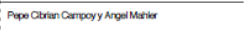 \\
\hline Dos Dearass & & & & 1958 & Kunteand \\
\hline Dos Locose En Q Are & & & & 1978 & Pallo ohioge \\
\hline Dos Mes Dos & & & & 2012 & Dosogopian \\
\hline Dos Paves En Aquoros & & & 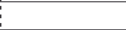 & 2014 & Jinny Haymerd \\
\hline Dos Son Famila & & & 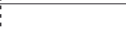 & 2017 & Hoo Gon \\
\hline Dr Cindido Pover, Stres & & & i & 1962 & Enib Vera \\
\hline Drock & & & & 2011 & Pese catrin canpoy \\
\hline Droula & & & $i$ & 1992 & Farcse Foud Coppoda \\
\hline
\end{tabular}

\begin{tabular}{|c|c|c|c|c|c|c|}
\hline No SERIE & N OBRA & Títuเo & TEMP. & NOMBRE / CANTIDAD DE CAPITULOS & ANNO & DIRECTOR \\
\hline 7718 & 8831 & Casi Angeles & 4 & Tiempo De Cambios & 2010 & Flavio Rondalli Y Mauro Scandolari \\
\hline 7718 & 9129 & Casi Angeles & 4 & La Resistencia: Segunda Parte & 2011 & Mauro Scandolari, Flavio Rondelli \\
\hline 7718 & 9128 & Casi Angeles & 4 & La Resistencia:Primera Parte & 2010 & Mauro Scandolari, Flavio Rondelli \\
\hline 7718 & 9127 & Casi Angeles & 4 & Un Pacto & 2010 & Mauro Scandolari, Flavio Rondelli \\
\hline 7718 & 9126 & Casi Angeles & 4 & Aleluya & 2010 & Mauro Scandolari, Flavio Rondelli \\
\hline 7718 & 9125 & Casi Angeles & 4 & Detenidos En Un Momento & 2010 & Mauro Scandolari, Flavio Pondelli \\
\hline 7718 & 9124 & Casi Angeles & 4 & La Explicación" & 2010 & Mauro Scandolari, Flavio Pondelli \\
\hline 7718 & 9123 & Casi Angeles & 4 & Lo Que No Se Puede Cambiar & 2010 & Mauro Scandolari, Flavio Pondelli \\
\hline 7718 & 9122 & Casi Angales & 4 & Cayendo Lentamente & 2010 & Mauro Scandolari, Flavio Pondelii \\
\hline 7718 & 9016 & Casi Angeles & 4 & La Hora De Vower A Casa & 2010 & Flavio Rondelli, Mauro Scandolari \\
\hline 7718 & 9015 & Casi Angeles & 4 & Un Ladrillo & 2010 & Flavio Rondelli, Mauro Scandolari \\
\hline 7718 & 9014 & Casi Angeles & 4 & Tu Canción & 2010 & Flavio Rondelli, Mauro Scandolari \\
\hline
\end{tabular}

Figura 16. Informe de obras liquidadas (fuente: SAGAI). 


\section{Los DRM en las obras audiovisuales}

A los fines de este estudio, DRM será toda tecnología utilizada por los titulares de derechos de autor para controlar el uso del material digital que distribuyen y para limitar el uso del contenido de acuerdo con sus propósitos. No son de uso exclusivo en la industria audiovisual, ya que los audiolibros, las tiendas digitales de música y las señales satelitales, entre otros, utilizan mecanismos equivalentes. ${ }^{91}$ Es un recurso necesario desde que la digitalización de las obras y su distribución por internet requieren identificarlas y hacer su seguimiento. Al respecto, el Tratado de la OMPI sobre Derecho de Autor (TODA o WCT, en inglés) prevé en el artículo 11 la obligación de las partes contratantes de "proporcionar protección jurídica adecuada y recursos jurídicos efectivos contra la acción de eludir las medidas tecnológicas efectivas" utilizadas por los autores y titulares para proteger sus obras o para permitir o prohibir ciertos actos respecto a estas. A su vez, en el artículo 12 se establecen obligaciones semejantes para impedir que "se suprima o altere sin autorización cualquier información electrónica sobre la gestión de derechos” o que se distribuyan, importen para su distribución, emitan o comunique al público, sin autorización, ejemplares de obras "sabiendo que la información electrónica sobre la gestión de derechos ha sido suprimida o alterada sin autorización". ${ }^{92}$

En el mismo TODA se aclara que se entiende por "información sobre la gestión de derechos" la información que identifica a la obra, a su autor, al titular de cualquier derecho sobre la obra, o información sobre los términos y condiciones de utilización de las obras y todo número o código que represente tal información, cuando cualquiera de estos elementos de información esté adjunto a un ejemplar de una obra o figuren en relación con la comunicación al público de una obra. ${ }^{93}$ De aquí que la información para la gestión

91 Respecto al modo general en el que actúan los DRM en las plataformas digitales, cfr. Kim (2019).

92 Estas normas tienen sus paralelos equivalentes en los artículos 18 y 19 del Tratado de la OMPI sobre Interpretación o Ejecución y Fonogramas (TOIEF o WPPT, en inglés) y en los artículos 15 y 16 del Tratado de Beijing sobre interpretaciones y ejecuciones audiovisuales.

93 Estas obligaciones de los Gobiernos -que son facultades de los titulares- se 
de derechos, además de ser analizada desde los aspectos prácticos y económicos, constituye un elemento fáctico del tipo legal de las normas que establecen mecanismos de protección. Es decir que no solo queda protegida la OA en sí misma, sino los elementos que permiten identificarla, hacer su seguimiento o permitir su uso bajo ciertas condiciones establecidas por el titular o por otros titulares de derechos incorporados a la OA, como los autores de la música, los intérpretes y los actores, entre otros.

Esta disposición ha sido incorporada a algunas de las legislaciones nacionales de los países objeto de este estudio. Así, el artículo 46, inciso D) de la Ley 9739 de la República Oriental del Uruguay establece que

Será sancionado con pena de tres meses de prisión a tres años de penitenciaría quien altere o suprima, sin autorización del titular de los derechos protegidos por esta ley, la información electrónica colocada por los titulares de los derechos de autor o conexos, para posibilitar la gestión de sus derechos patrimoniales y morales, de modo que puedan perjudicarse estos derechos. La misma pena se aplicará a quien distribuya, importe con fines de distribución, emita o comunique al público, sin autorización, ejemplares de obras, interpretaciones o fonogramas, sabiendo que la información electrónica colocada por los titulares de derechos de autor o conexos, ha sido suprimida o alterada sin autorización.

Los DRM más conocidos, además de los identificadores universales y los metadatos incorporados por el productor audiovisual o sus agentes, son las marcas de agua y las huellas digitales. Estos códigos son incorporados a la OA en la etapa de posproducción por el agregador o bien por cada plataforma. El procedimiento de uso de los DRM incluye un encriptado del contenido (DRM packaging) y un desencriptado posterior (playback process) mediante el acceso a la llave o código que permite abrir dicho contenido (encryption key management). Los DRM y las condiciones de uso son transmitidos o puestos

aplican tanto a los derechos exclusivos como a los de remuneración. Cfr. Ficsor (2003, p. 221 y ss.). 
a disposición por separado del contenido mismo. Estas condiciones pueden indicar la validez y vigencia de la licencia de cada usuario y la cantidad de veces que cada obra puede ser visualizada, entre otras.

Cada buscador (browser) utiliza su propio sistema de DRM, por tanto, habrá uno para el entorno Apple, otro para Microsoft, otro para Google, etc. ${ }^{94} \mathrm{~A}$ su vez, las plataformas desarrollan sus llaves para cada entorno. Así, si Netflix ofrece la posibilidad de save (guardar un contenido para ver luego y sin conexión), requiere desarrollar dicha llave específica para tantos posibles entornos disponibles para los usuarios, sea Android, IOS, etc., dependiendo del dispositivo utilizado. Es un requisito ineludible para facilitar la portabilidad y la interoperabilidad, de aquí que las plataformas hoy día sean Multi-DRM. ${ }^{95}$ Debido a este mecanismo, los DRM requieren implementaciones en los dispositivos de los usuarios y en los servidores de las plataformas.

Junto con los DRM que permiten el disfrute legal del contenido, se suelen anexar otros que habilitan el seguimiento ante posibles infracciones. Son los llamados forensic DRM, los cuales le facilitan al titular de los derechos de autor de un contenido o a la plataforma de VOD descubrir un contenido distribuido ilegalmente. Son implementaciones que pueden detectar la marca de agua, rastrear al usuario, impedir que el usuario utilice el servicio o tomar medidas legales para evitar que la distribución ilegal continúe. A continuación, veremos los principales sistemas que implementan estos recursos, los cuales incluso pueden prevenir prácticas como el camcording (filmación de la pantalla de la sala de cine y posterior distribución de la grabación, que implica el paso de digital a analógico y otra vez de analógico a digital) o el $P C$ screen recorder (captura de pantalla de la imagen de la computadora en formatos MOV o MP4). ${ }^{96}$

94 A modo de ejemplo, se pueden consultar las especificaciones que sigue Widevine DRM, utilizado por Google Play, YouTube, Netflix, Hulu, Amazon, entre otros. Cfr. https://www.widevine.com/solutions/widevine-drm.

95 Cfr. Kim (2019). Los buscadores de Microsoft y Edge solo permiten el uso de PlayReady DRM. Google Chrome utiliza Google Widevine Modular DRM; Safari de Apple utiliza el DRM FairPlay Streaming; Mozilla y Firefox también utilizan Widevine Modular DRM, como Chrome.

96 Para ver más en detalle las tecnologías de forensic watermarking se pueden 


\subsection{Los fingerprints, marcas de agua y otros identificadores digitales en las OA}

ISAN, EIDR y otros identificadores únicos no son en sí mismos un sistema para proteger el contenido, pero cuando se utilizan junto con los sistemas de seguimiento y detección de contenido mejora considerablemente la eficiencia del ecosistema. Los medios tecnológicos permiten que los identificadores actúen en conjunto con las huellas dactilares y marcas de agua, permitiendo el escaneo de redes, la detección de la presencia de OA en la oferta de determinadas plataformas y la verificación de la tasa de uso de cada OA. ${ }^{97}$ Ambas técnicas son complementarias y pueden utilizar los identificadores universales hasta aquí desarrollados, unos para permitir el disfrute de los contenidos y otros para efectuar el seguimiento de los usos ilegales. ${ }^{98} \mathrm{~A}$ continuación se puede ver el esquema de funcionamiento combinado de metadatos y DRM, de acuerdo a lo propuesto por uno de los proveedores existentes.

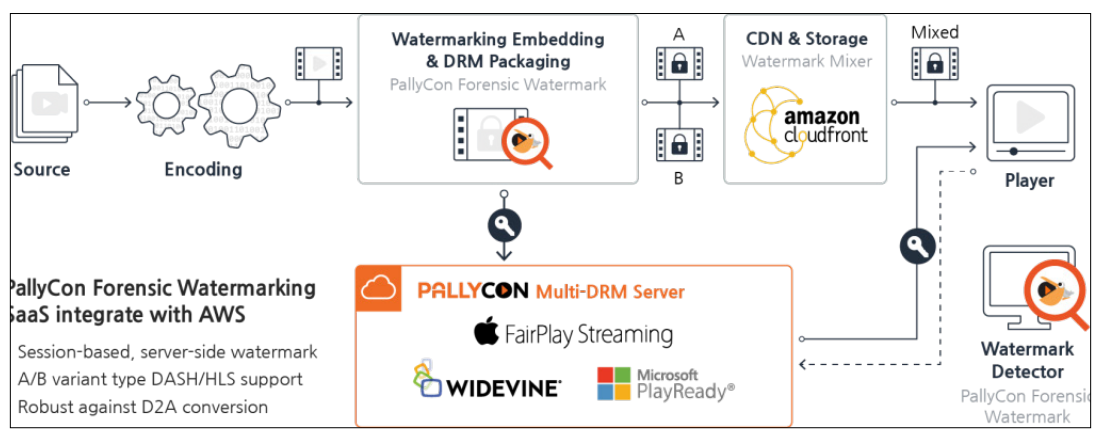

Figura 17. Flujograma de inserción de marcas de agua (fuente: PallyCon Forensic Watermarking and Multi-DRM workflow). ${ }^{99}$

En cualquier caso, son parte de los metadatos embebidos (incor-

consultar las especificaciones de la industria norteamericana en Movielabs (2020).

97 Para los conceptos básicos de marcas de agua y huellas digitales, cfr. Milano (s.f.).

98 Cfr. Hsieh et al. (2014).

99 Disponible en: https://medium.com/pallycon/how-netflix-protects-contents-part-2-33c1b60002a3. 
porados) o vinculados a la OA, ya sean descriptivos, estructurales (como un capítulo o temporada dentro de una serie), administrativos, técnicos o de preservación. ${ }^{100} \mathrm{El}$ uso de identificadores y metadatos requiere utilizar estándares para la creación, la gestión y el intercambio de información, brindando homogeneidad e interoperabilidad. Esas normativas uniformes indican cómo y por qué deben capturarse ciertos metadatos, permitiendo comprender fácilmente los metadatos creados por otros y reduciendo al mínimo los obstáculos del intercambio de información entre sistemas. ${ }^{101}$ Los metadatos pueden almacenarse en hojas de cálculo de Excel, como archivos XML o en bases de datos como sistemas de gestión de contenidos y depósitos institucionales, así como en otros formatos. Sea cual fuere la forma en la que se almacenen los metadatos, el uso de normas para crearlos y estructurarlos hará que se comprendan más ampliamente y sean más interoperables. ${ }^{102}$

A modo de ejemplo, para la detección de usos no autorizados, ISAN permite identificar de forma inequívoca y automática el contenido específico al que afecta la infracción. Así lo hace el sistema de protección de contenido AACS para discos Blu-ray y otros medios ópticos (https://aacsla.com/), o bien directamente el propietario del contenido para identificar sus obras protegidas con la identificación de contenido de YouTube o dentro del sistema francés Hadopi. ${ }^{103}$

100 Cfr. AVPS-NEDCC Northeast Document Conservation Center, Fundamentals of AV Preservation Textbook, https:/www.nedcc.org/fundamentals-of-av-preservation-textbook/chapter-4-introduction/chapter-4-section-5.

101 Cfr. Polo Carrión et al. (2011).

102 Filmstandars.org propuso el estándar EN15744 como un catálogo mínimo de metadatos que deberían ser obligatorios para las obras audiovisuales en la Unión Europea. Cfr. http://filmstandards.org/fsc/index. php?title=EN_15744. Respecto a cómo se caracteriza cada uno de dichos metadatos, propuso a su vez el estándar EN15907. Cfr. http://filmstandards. org/fsc/index.php?title=EN_15907. Como documento actualizado y comprensivo de los estándares para metadatos de obras audiovisuales en la Unión Europea puede consultarse EFG European Film Gateway Data Provider Handbook, disponible en: https://www.efgproject.eu/downloads/EFG_DataProviderHandbook_2020.pdf.

103 En un reciente informe del Ministerio de Cultura de Francia se analiza la forma en la que se pueden utilizar las herramientas digitales para la protección 
Existen múltiples formas de vincular el ISAN a la obra utilizando estándares audiovisuales. ${ }^{104}$

En el caso del EIDR, los metadatos no son incrustados directamente, sino a través del ID que remite a ellos, el cual es incorporado al master original de la OA o de sus diferentes versiones. Este ID del EIDR identifica el contenido, una específica versión o edición y una secuencia de imágenes. ${ }^{105}$

\subsubsection{Uso de marcas de agua en la OA}

Las marcas de agua se utilizan para hacer el seguimiento de archivos individuales, ayudar a identificar quién creó un determinado contenido y establecer si el contenido se obtuvo por medios legítimos. Una marca de agua es una pequeña cantidad de datos añadidos y a menudo ocultos dentro de un archivo digital, que incluso puede constituir solo una identificación única o un número, difícil de eliminar sin dañar o distorsionar la imagen o difícil de encontrar si no se conoce su acceso o encriptación. También puede consistir en los mismos datos repetidos en muchos fotogramas del archivo audiovisual. Cualquiera sea el modo, deben resultar "invisibles" para el consumidor sin ir en detrimento de la calidad del contenido.

Para garantizar la máxima solidez de los sistemas de marcas de agua, el ISAN no se fija directamente al contenido mediante tecnologías de marcas de agua ocultas. De hecho, existe un vínculo directo entre la calidad de una marca oculta, su solidez a los ataques, como el intento de eliminar la marca, y la información contenida en dicha marca de agua (la identificación o etiqueta). Por lo tanto, cada

de los derechos de propiedad intelectual en las plataformas audiovisuales. El llamado rapport Mochon se enmarca en el artículo 17 de la Directiva sobre los Derechos de Autor y Derechos Afines en el Mercado Único Digital. Cfr. Mochon et al. (2020).

104 Disponible en: https://support.isan.org/hc/en-us/articles/360025250652-ISAN-in-Audiovisual-Standards.

105 Respecto a los requisitos técnicos para introducir el EIDR ID en el master, se puede consultar en Entertainment Identifier Registry (2016). La biblioteca de documentos de EIDR para la aplicación de estándares está accesible en: https://www.eidr.org/standards-and-interoperability/. 
proveedor de soluciones ha desarrollado e implementado su propio etiquetado para hacerlo funcionar con su tecnología; algunos usan códigos cortos, otros usan una marca de tiempo, etc. ${ }^{106}$

Por lo tanto, el enfoque de ISAN es no degradar las tecnologías de los proveedores, sino vincular los códigos ISAN a la etiqueta del proveedor en el nivel del sistema de marca de agua mediante codificadores y decodificadores. Cuando se codifica o decodifica una marca de agua, el usuario ve un ISAN, el que por detrás se asigna a la etiqueta del proveedor. En definitiva, lo que importa no son los bits digitales que están ocultos en el contenido, es decir, la etiqueta del proveedor, sino cómo estos, una vez recuperados en un contenido infringido, pueden vincularse de manera inequívoca y automática a un contenido específico: el ISAN y sus metadatos. Varios proveedores de marcas de agua realizaron dicha implementación de ISAN.

EIDR también permite la utilización de marcas de agua, como, por ejemplo, el sistema desarrollado entre CIMM (Coalition for Innovative Media Measurement https://cimm-us.org/) y KantarMedia. Se trata del OBID (Open Binding of Content Identifiers) que permite codificar el ID de EIDR en una pista de audio, la que es superpuesta en el código del archivo. ${ }^{107}$ Una versión avanzada es el sistema TAXI (Trackable Asset Cross-Platform Identification), que permite la persistencia de la marca de agua a través de múltiples y simultáneas plataformas (Broussard, s.f.). Si bien su uso inicial fue para identificar piezas publicitarias en las emisiones de señales en beneficio de anunciantes y agencias, cualquier contenido audiovisual puede ser identificado y detectado con estas marcas de agua.

\subsubsection{Uso de huellas digitales en la $O A$}

Las huellas digitales no embeben ninguna información en el archivo,

106 A modo de ejemplo, se puede revisar la experiencia de Streaming Video Alliance, una iniciativa entre varios operadores del ecosistema de la televisión que utilizan mecanismos de marcas de agua para contenidos en vivo, denominado ContentArmour. Cfr. https://www.streamingvideoalliance.org/document/forensic-watermarking-implementation-considerations-for-streaming-media/.

107 Cfr. Mears y Kerautem (s.f.). 
sino que analizan el vídeo y/o el audio para determinar las características únicas del contenido. El patrón identificado se almacena en una base de datos y se puede utilizar para reconocer el contenido en el futuro. Para que un sistema de huellas digitales sea eficaz, debe estar asociado a una base de datos que vincule la huella con el contenido cuando el sistema identifique el mismo contenido otra vez. En el caso de las $\mathrm{OA}$, estos sistemas requerirían una capacidad de manejo de datos inconmensurable, ante lo cual se suele almacenar solo una muestra representativa de fotogramas o bien signos incorporados a la emisión de un programa de televisión, como el logotipo de la señal. Esta muestra se suele llamar DNA o código genético de la OA. El sistema permite identificar la obra y sus distintas versiones, con lo cual es posible efectuar asignación de ingresos de modo preciso.

El ISAN generalmente se adjunta a la huella digital en la base de datos de huellas digitales. Por tanto, permite identificar de forma inequívoca y automática el contenido detectado por el sistema de huellas digitales y proporcionar informes con referencias ISAN que pueden ser procesados por otras aplicaciones. ISAN, ISRC e ISWC son utilizados, por ejemplo, por el sistema de huellas digitales de BMAT (https://www.bmat.com) para proporcionar informes de uso que pueden ser procesados electrónicamente por las SGC. Otro tanto realiza Kantar Media para la medición de audiencias y de publicidad. ${ }^{108}$

Una solución de huella digital específica para la industria audiovisual la provee Signature https://institut.ina.fr/en/services/image-sound-software/signature.

\subsection{Tecnologías de blockchain para la gestión de obras audiovisuales}

Las tecnologías de blockchain se pueden utilizar para el registro de obras protegidas por el derecho de autor. Si bien es una alternativa disponible para las oficinas de propiedad intelectual y demás actores del ecosistema, su uso todavía es muy limitado. En su desarrollo

108 https:/www.kantarmedia.com/us/our-products/audience-intelligence/content-detection-technologies. 
actual, su utilidad está relacionada principalmente con la prueba de la creación, titularidad y contenido, pero los metadatos generados para el registro pueden incorporarse a las versiones de la OA para su seguimiento más preciso y determinar derechos y remuneraciones. ${ }^{109}$ Esto se debe a que el registro por blockchain se puede asociar a los llamados "contratos inteligentes", los cuales facilitan las condiciones de uso de las obras. Adicionalmente, la encriptación de la información inherente al sistema torna al circuito informativo de una gran fiabilidad y trazabilidad (Clark y Burstall, 2019).

Una de las ventajas que podría traer el uso del blockchain por sobre los sistemas de Content ID es que el titular puede determinar de modo anticipado e indubitable qué usos o remuneraciones habilita de modo general para sus obras, incorporando un vínculo a un contrato inteligente sin depender de la política de tal o cual proveedor o plataforma. El sello criptográfico es más robusto que las marcas de agua y las huellas dactilares (Savelyev, 2017). Tanto la distribución como los pagos automáticos se verían facilitados. ${ }^{110}$ Por otra parte, los bloques criptográficos introducidos como metadatos en las $\mathrm{OA}$ también deben ser considerados como parte de la información pro-

109 De modo general, para el funcionamiento del blockchain en relación con la propiedad intelectual, puede consultarse Rose (2020). Para una explicación más detallada de la estructura del blockchain, cfr. Shackelford y Myers (2016).

110 Esto es por ejemplo lo que prevé la patente US 2018 / 0285996 A1 METHODS AND SYSTEM FOR MANAGING INTELLECTUAL PROPERTY USING A BLOCKCHAIN, titularidad de FutureLab Consulting Inc. "A system and methods for managing intellectual property using a blockchain are provided which may include one or more elements which forms a comprehensive foundation for an eco-system for innovation and intellectual property management. The elements may include: an intellectual property distributed ledger, an intellectual property digital policy server, non-binary trust models, automatic ontology induction, modifications to the blockchain "mining" and "proof of work" system, appstore for related applications, partial transparency transactionalized search engine, persistent and encapsulated software trust objects, licensing royalty smart contract with auditable payment tracking, micro-equity incentives, automated fraud detection intellectual property management dashboards, innovation workflow broker, innovation optimization tools, disruption mapping, and intelligent just-intime learning. The system combines and integrates these functions to enable personal, intra-enterprise, inter-enterprise and extra-enterprise recordation, 
tegida por DRM. De aquí que su uso para la gestión de derechos sea una consecuencia lógica del sistema (Tresise et al., 2018).

Si bien el uso de la criptografía y el blockchain para la gestión de grandes repertorios todavía no es una realidad extendida, es importante tener en cuenta que para su implementación será necesario transitar antes las etapas de identificación uniforme de la OA, sus titulares y los derechos asociados. En el paso de las posibilidades teóricas a una práctica general se deben resolver problemas técnicos y de interoperabilidad (Gürkaynak et al., 2018).

\section{Experiencias sobre el uso de la información}

\section{1. la inteligencia artificial en la identificación y gestión de OA} Cómo hemos visto hasta aquí, la gestión de la información de las OA requiere una gran capacidad de procesamiento e interoperabilidad de los sistemas, además de una adecuada organización y carga de los datos provenientes de la documentación. De aquí que de modo creciente se utilicen las herramientas de big data, data mining, machine learning y deep learning, todos recursos de la disciplina de la inteligencia artificial (IA). De estas tecnologías, probablemente el machine learning sea la más requerida para automatizar los procesos. ${ }^{111}$ Utiliza algoritmos y modelos estadísticos para permitirles a los sistemas el aprendizaje y mejora a partir del ensayo y error, simulando el modo humano de utilización de los datos de experiencia. Mediante el machine learning, el sistema computacional puede realizar tareas de clasificación a partir de imágenes, texto o sonido. Los modelos se entrenan utilizando un gran conjunto de datos de

collaboration, searchability and its benefits, licensing and tracking of information regarding intellectual property over a networked distributed computing system". Cfr. También la solicitud de patente USPTO 20200374106 16/667847, denominada SYSTEM OR METHOD ON IMPLEMENT RECORD LEVEL ACCESS ON METADATA DRIVEN BLOCKCHAIN USING SHARED SECRETS AND CONSENSUS ON READ.

111 Un ejemplo es la iniciativa URights, entre SACEM e IBM, para aplicar la tecnología Watson de machine learning en la identificación de obras musicales, incluyendo las plataformas de VOD. Cfr. http://www.urights.net/. 
varias capas y arquitecturas de redes neuronales. ${ }^{112}$ Los sistemas se basan en reglas que utilizan conjuntamente las bases de datos de información y las reglas para automatizar los procesos de inferencia (Chan-Olmsted, 2019).

Más allá de la optimización, la IA ofrece amplias funciones relacionadas con el contenido de las plataformas. Estas funciones son la agregación, la extracción, el etiquetado, la supervisión y el control del contenido. La clave aquí está en la habilitación de una máquina para complementar las decisiones y comportamientos humanos, haciendo así el proceso de gestión de contenidos más efectivo y eficiente. La IA en la gestión de contenidos parece ser una aplicación importante y temprana de las empresas de medios de comunicación. Una encuesta de la industria encontró que el $47 \%$ de los encuestados utilizan la IA para crear, generar y adjuntar etiquetas de metadatos a los extractos de forma automatizada para simplificar las búsquedas de contenido y acelerar la recuperación de los extractos. Esto es especialmente importante para quienes disponen de grandes catálogos de contenido (Chan-Olmsted, 2019).

Las posibilidades son enormes. Las expresiones sintácticas de programación hacen uso de los identificadores universales como ISAN, ISWC o ISRC como parte integral del proceso. De hecho, las características de estos números o códigos comparten varias de las características necesarias para que las huellas digitales sean más robustas a la hora de evitar la circunvención de los DRM. ${ }^{113} \mathrm{~A}$ modo de ejemplo, los mecanismos de autorización de uso de las plataformas TVOD utilizan las redes neuronales para brindar acceso a los contenidos elegidos por el usuario. ${ }^{114}$ Existen diversas tecnologías que hacen aplicación de la inteligencia artificial para la gestión de repertorios, detección de infracciones, remuneración de titulares o baja de contenidos. Algunas de estas tecnologías se encuentran protegidas por patente. ${ }^{115}$

112 A modo de ejemplo, el machine learning puede resolver conflictos de homonimia respecto al título de la obra o bien en el subtitulado. Cfr. Rice et al. (2019).

113 Cfr. Chen et al. (2019).

114 Cfr. García et al. (2007).

115 A modo ejemplificativo mencionaremos dos. La patente US 2018/0247380 
Las OTT y, de modo más general, la industria de medios y telecomunicaciones recurren a la IA con las siguientes finalidades: recomendaciones y asistencia en la búsqueda de contenido, participación y preferencias de la audiencia, comportamiento de la audiencia, experiencia aumentada, mejoras en la gestión de mensajes, gestión y administración de contenido, creación de contenido, información del público y automatización operativa. En nuestro caso, interesa especialmente la gestión y administración de contenido. Una utilidad de la IA y el machine learning en particular es su aplicación a las bases de datos de números estándar. ISAN, por ejemplo, lo utiliza para evitar la deduplicación de OA al registrar códigos ISAN, mapear cualquier esquema de base de datos audiovisual con el esquema de datos del Registro ISAN o bien hacer coincidir las bases de datos externas con el registro ISAN para difundir los códigos ISAN existentes.

\subsection{Content ID}

La expresión Content ID representa mecanismos muy diversos, por medio de los cuales las plataformas y otros actores del ecosistema utilizan las huellas digitales y marcas de agua para detectar y administrar la información de las obras visualizadas por los usuarios.

\subsubsection{YouTube y convenios de monetización}

La plataforma YouTube dispone de una OTT con servicios de AVOD y de TVOD. En la versión de AVOD, que fue la primera y es la más utilizada, tiene una práctica establecida con sus partners en la que utiliza identificadores personalizados que indican un valor único para poder gestionar los contenidos alojados en la plataforma. ${ }^{116}$ Pueden ser identificadores creados específicamente para cada

Al, referida a MANAGING COPYRIGHTS OF CONTENT FOR SHARING ON A SOCIAL NETWORKING SYSTEM, titularidad de Facebook, Inc. La patente US 7,779,058 B2, referida a METHOD AND APPARATUS FOR MANAGING A DIGITAL INVENTORY OF MULTIMEDIA FILES STORED ACROSS A DYNAMIC DISTRIBUTED NETWORK, titularidad de Ronald Raymond Shea.

116 Cfr. https://support.google.com/moviestvpartners/answer/2987836 y 
contenido o uno de los identificadores estandarizados a los que ya nos referimos, como el EIDR o el ISAN. YouTube recomienda utilizar un único identificador por contenido para la disponibilidad y la transferencia, ya que mejora la creación de informes y el seguimiento. El identificador personalizado puede ser creado por el titular o, en su defecto, se crea automáticamente al subir un contenido a la plataforma. También se puede identificar cada contenido distinguiendo por temporada y por episodio, lo cual será tenido en cuenta para los reportes.

Los archivos con los contenidos son subidos por los titulares a los servidores de YouTube junto con los identificadores y las instrucciones de gestión, ya sea para alojarlos a los solos fines de crear la huella digital o bien tomar la decisión de hacerlos públicos. La huella permite efectuar un seguimiento de los contenidos para evitar la piratería o establecer mecanismos de monetización, de acuerdo con las indicaciones del titular, que pueden consistir en dar de baja, monetizar, geolocalizar (limitar por territorios) o limitar el tiempo de visualización. El sistema realiza una comparación de imagen y sonido de cada contenido, detecta las imágenes de contenidos similares subidos por otros usuarios y aplica las instrucciones recibidas del titular.

Para configurar el identificador personalizado, al momento de subir un contenido se introduce la información básica: título, descripción, las miniaturas que verá el usuario, la lista de reproducción, el público destinatario, restricciones por la edad de los usuarios y si es un contenido creado para niños. También se debe indicar si el video incluye una promoción pagada, cuando corresponda. El titular puede agregar etiquetas, consistentes en palabras clave descriptivas para corregir errores de búsqueda y para orientar las preferencias del consumidor. Se detalla el idioma original, las versiones y si contiene subtítulos, así como el lugar y fecha de producción o grabación. Es posible introducir la información de licencias y distribución, como también si se trata de una licencia de derechos de autor estándar o bien bajo Creative Commons. El titular también puede decidir si

https://support.google.com/moviestvpartners/answer/7540024?hl=en\&ref_ topic $=6162347$. 
el video puede incorporarse en otros sitios web. Otra información relevante es el género o categoría, por ejemplo, si es educativo o comedia. Entre otras opciones, se pueden permitir o no comentarios en el video así como la visibilidad de la cantidad de "Me gusta" y "No me gusta".

Los partners que utilizan el sistema de coincidencias pueden habilitar la opción de reconocimiento para tramitar reclamos cuando el contenido subido por otros usuarios coincida parcialmente con el archivo de referencia subido por el titular. Los reclamos se generarán automáticamente. La otra opción es decidir monetizar esos contenidos cuando los usuarios los seleccionen y visualicen, compartiendo YouTube la recaudación publicitaria a razón del 55\% el titular y $45 \%$ YouTube. ${ }^{117}$ Esta distribución solo se aplica a los contenidos que hayan sido visualizados y que estén patrocinados por spots publicitarios. Esta última opción está disponible para los productores de la región a través de EGEDA.

El sistema de monetización a través de Content ID también es utilizado por organismos de radiodifusión mediante la puesta a disposición de las grabaciones de los programas emitidos previamente por sus señales, sean o no obras audiovisuales. YouTube permite agregar elementos visuales al final del video (pantalla final) así como contenido interactivo al video (tarjetas), con la finalidad de ofrecer otros contenidos a los consumidores o recordarles eventos en vivo o estrenos. El consumidor incluso puede guardar sus preferencias para que le lleguen avisos personalizados.

YouTube dispone de Analytics (https://studio.youtube.com/), un servicio de reporte que muestra los datos más relevantes respecto a las reproducciones de los contenidos del partner. Se presentan las principales métricas vinculadas al tráfico del sitio propio del socio, como el tiempo de reproducción (en horas), las vistas, los suscriptores y los rendimientos. Si se es parte del Programa de socios de YouTube, se pueden consultar los ingresos del último mes o de un período mayor, desglosados por cada video, con las fuentes de ingreso para el período seleccionado.

117 A octubre de 2020, a este convenio habían adherido 440 productores de Iberoamérica con 12000 OA Cfr. https://www.egeda.com.ar/EW_Pirateria.asp. 
Este es un ejemplo de los reportes que presenta YouTube:

\begin{tabular}{|c|c|c|}
\hline Field & Description & Example \\
\hline video,id & $\begin{array}{l}\text { The Unique and persistent } \\
\text { identifier of the video as } \\
\text { allocated by YouTube. }\end{array}$ & WvyGIGII058 \\
\hline video title & $\begin{array}{l}\text { The title of the video as } \\
\text { provided by the uploader. }\end{array}$ & "Amazing vacations in SFO" \\
\hline work title & $\begin{array}{l}\text { Asset title for the Movie, Show } \\
\text { Episode, Web asset... }\end{array}$ & Aliens \\
\hline asset_type & $\begin{array}{l}\text { Defines the asset type claimed } \\
\text { in the video }\end{array}$ & Web, TV, Episode... \\
\hline asset_id & $\begin{array}{l}\text { Asset ID(s) of assets claiming } \\
\text { the video }\end{array}$ & ELZ1LTZJO3U \\
\hline $\begin{array}{l}\text { Year of } \\
\text { Production }\end{array}$ & $\begin{array}{l}\text { Year of production of the } \\
\text { movie or Series, as provided } \\
\text { by the Studio }\end{array}$ & 2012 \\
\hline ISAN & $\begin{array}{l}\text { International Standard AN } \\
\text { Number }\end{array}$ & $00000000 A 978000000000000$ \\
\hline EIDR & EIDR Number & $10.5240 / 0000-2345-5432-7858-6543-C$ \\
\hline views & $\begin{array}{l}\text { Total views for the video over } \\
\text { the reporting Month for the } \\
\text { reporting Territory }\end{array}$ & 500000 \\
\hline gross_revenue & $\begin{array}{l}\text { Total gross revenue for the } \\
\text { video in the reporting month } \\
\text { and territory }\end{array}$ & 1000.00 \\
\hline
\end{tabular}

Tabla 5. Reporte de YouTube (fuente: YouTube).

\subsubsection{Signature}

Signature es un software desarrollado y ofrecido por el INA (Institut National de l'Audiovisuel, Francia) para ser utilizado como huella digital en la identificación de secuencias de video. ${ }^{118}$ Inicialmente se trató de un desarrollo para la plataforma de distribución de contenidos MEDIAPRO, pero en la actualidad el servicio está disponible para terceros de todo el mundo a través de SaaS (software as a servi$c e$ ). Signature permite identificar contenido protegido por propie-

118 Cfr. https://institut.ina.fr/en/services/image-sound-software/signature. 
dad intelectual, asegurar el cumplimiento de las condiciones de uso de dicho contenido y desarrollar estrategias de monetización por su explotación. Utiliza tanto ISAN como EIDR para identificar las OA.

Signature puede ser utilizado para identificar y seguir transmisiones en vivo, como eventos deportivos o conciertos, ya que las huellas digitales se comparan automáticamente en menos de un minuto y sin intervención humana. INA supervisa actualmente alrededor de cien señales de TV automáticamente en tiempo real para identificar copias de sus archivos distribuidos. Entre sus principales usuarios se puede mencionar a DailyMotion, de fuerte presencia en la región (https://www.dailymotion.com/ar). También colabora con las SGC para la distribución de derechos.

Sus especificaciones permiten determinar cuándo y cómo puede ser utilizado cada contenido, durante qué período, territorios de uso y distribución de los ingresos generados. Adicionalmente, los titulares de derechos tienen la opción de mantener activo su contenido registrado en las bases de datos del INA para poder vincularlos a servicios de antipiratería.

Signature también puede ser utilizado por plataformas de servicios audiovisuales para identificar contenidos, en la medida que se utilice la base de datos del INA, con base en una cantidad mínima de horas de contenido. El mismo recurso de huella digital puede ser utilizado por proveedores de servicio de monitoreo de redes al detectar copias, incluso cuando se hubieran realizado modificaciones importantes en los archivos, superpuesto texto y gráficos a las imágenes, cambios de color o blanco y negro o utilizado tecnologías de compresión o cambios de formato. Para este servicio también se utiliza la base de datos central del INA y está disponible solo para los servicios de monitoreo en internet. También pueden operar asociado a terceras partes, como OpSec (https://www.opsecsecurity.com/) o TMG (https://www.tmg.eu/) para etiquetar los contenidos y realizar su seguimiento en las redes. ${ }^{119}$

119 En el caso de TMG, por ejemplo, utiliza ICE (Internet Copyright Enforcement) asociado a Signature para ejecutar políticas antipiratería con baja de 


\subsection{La medición de audiencias}

Otro uso muy relevante de la información sobre la obra audiovisual y los metadatos asociados, es la posibilidad de medir audiencias y preferencias de consumo. Veremos algunos de esos usos.

\subsubsection{COMSCORE}

COMSCORE (https://www.comscore.com/esl) es una empresa global con sede en Estados Unidos y de fuerte presencia en Latinoamérica, especializada en mediciones de audiencias en TV en todas sus formas, plataformas OTT y salas de cine. Para la exhibición en cines, mide el $95 \%$ de los ingresos de taquilla y asistencia de público mundial. Presta servicios a los estudios de producción audiovisual y a los distribuidores. También brinda informes sobre facturación y conciliación de flujos de fondos.

En el caso del audiovisual en plataformas de VOD, lo hace por los consumos en línea mediante el uso de dispositivos tanto fijos como móviles. Para la medición de audiencias en plataformas utiliza un método híbrido. En primer lugar, realiza un muestreo directo de usuarios voluntarios que tienen instalados audímetros en sus dispositivos. Se trata de un software que registra las páginas web visitadas. A eso se le suma la información proveniente de una herramienta analítica, DAX (Digital Analytix). Esta metodología híbrida se llama Unified Digital Measurement (UDM), la cual registra todos los visitantes del sitio web y ayuda a entender el tamaño y la calidad de la audiencia.

Otro de los servicios de COMSCORE es Video Metrix ${ }^{\oplus}$, Multiplataforma de COMSCORE que ofrece una visión total del consumo de video digital del consumidor en computadoras, teléfonos, tabletas y dispositivos OTT. Este servicio ofrece una medición de audiencia de video desagregada a través de contenido digital y anuncios, proporcionando detalles sobre el tamaño de la audiencia, la cobertura, fidelidad y composición demográfica. Estas características, entre otras, son analizadas para los canales de YouTube.

Respecto a otras plataformas de VOD, COMSCORE está avan-

contenidos incluida. Cfr. https://www.tmg.eu/services.html\#ice. 
zando en el etiquetado de páginas. En algunos casos analizan el tráfico, en otras muestran un panel con la interacción y tiempo de reproducción de los contenidos por parte de los usuarios. Los paneles se integran con usuarios que aceptaron compartir información cuando las aplicaciones interactúan con MyMetrics, un software de recolección, análisis y reporte de navegación.

\subsubsection{Content Pulse}

Content Pulse (https://bb.vision/content-pulse/) es una iniciativa de Business Bureau mediante la cual se efectúa el monitoreo de plataformas digitales para la medición de audiencia y disponibilidad de contenidos en las OTT. A octubre de 2020, la base de datos para el monitoreo incluía 1168 plataformas en 61 países, las cuales ponen a disposición 309458 películas y 2673386 episodios De los países objeto de este estudio, se encuentra activo el seguimiento de 214 plataformas de contenidos audiovisuales. De acuerdo con el estado de la base de datos de agosto de 2020, 52890 películas y 11051 series de los países objeto de estudio están presentes en las principales plataformas de VOD.

Los reportes son semanales y también incluyen análisis de afinidad de los contenidos y popularidad, pero no cantidad de usuarios. Respecto a las SGC, la herramienta es útil para identificar a los miembros presentes en obras que se transmiten online, en qué países y en qué plataformas. También permite ver el alcance de los contenidos locales y si alguna entidad tiene acuerdos con asociaciones de otros países, puede controlar esa recaudación y el cumplimiento de la reciprocidad.

Las obras identificadas en los reportes incluyen el EIDR y, en algunos casos, el ISAN. Cada nueva obra que se detecta es subida a la base de datos y puede formar parte de los futuros reportes.

La interfaz del usuario es muy versátil y permite distintos análisis, como algunos de los que se pueden ver a continuación: 


\section{Revista Iberoamericana de la Propiedad Intelectual}

$N^{\circ} 15$ (2021): 303-416

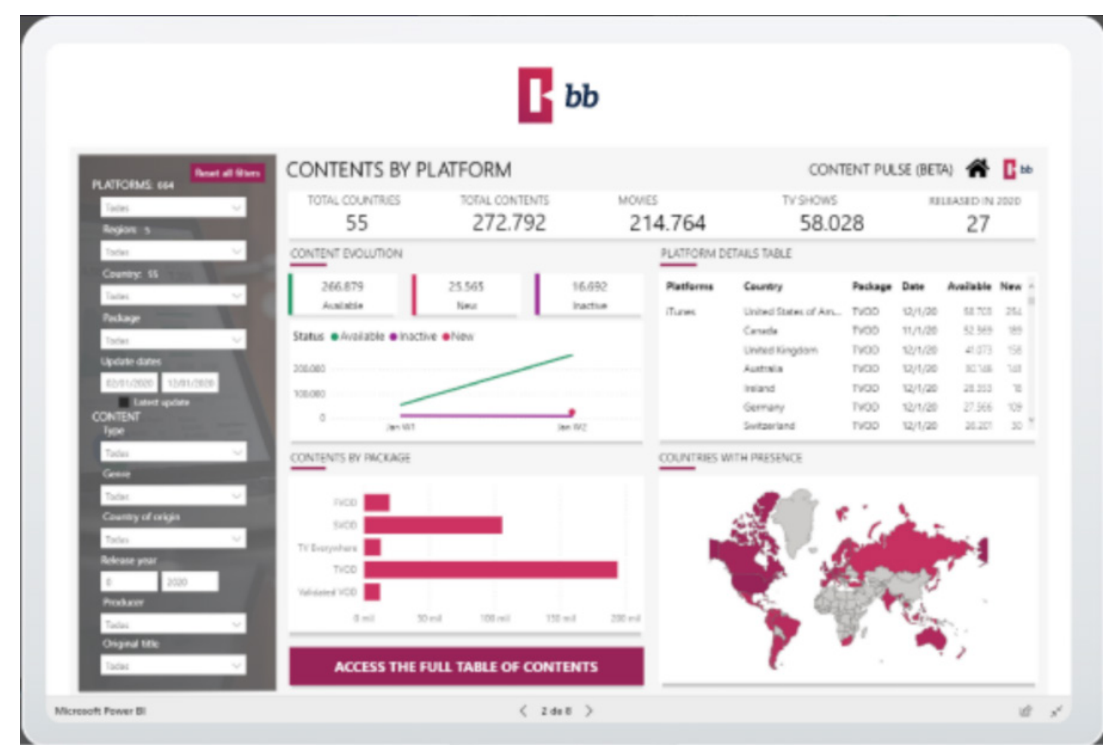

Figura 18. Pantalla de Content Pulse.

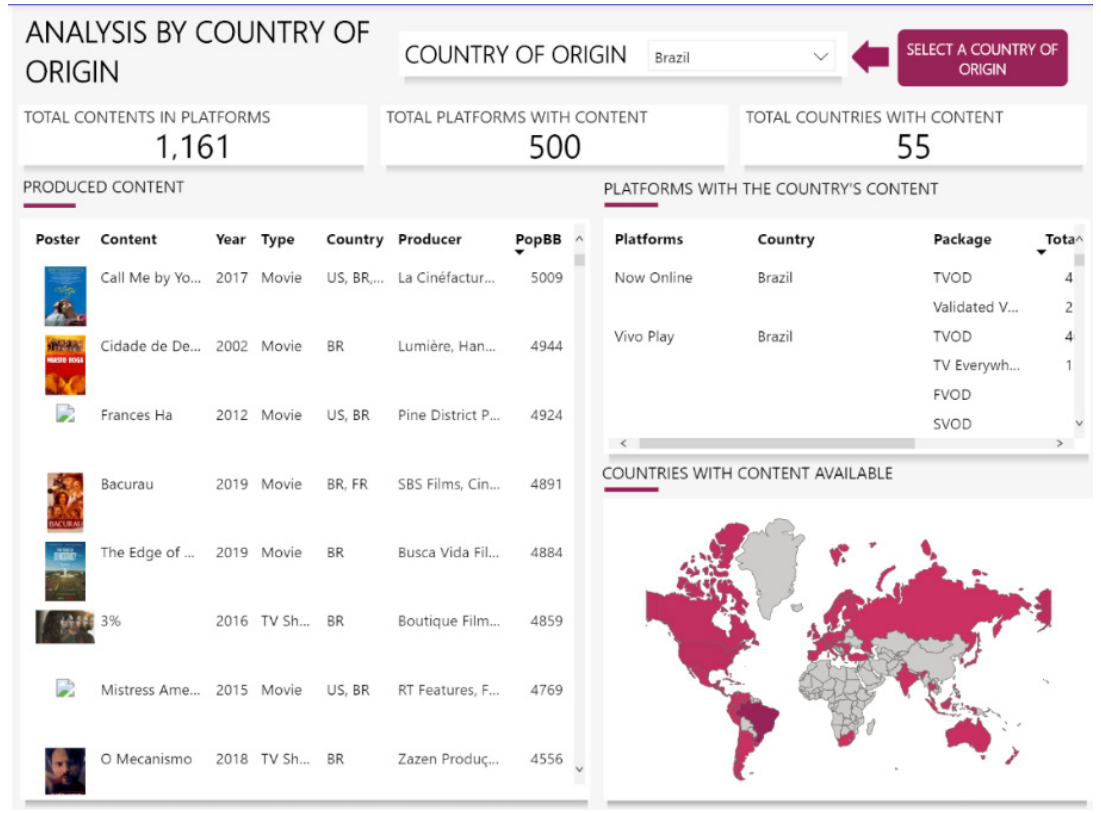

Figura 19. Pantalla con detalle de Content Pulse. 


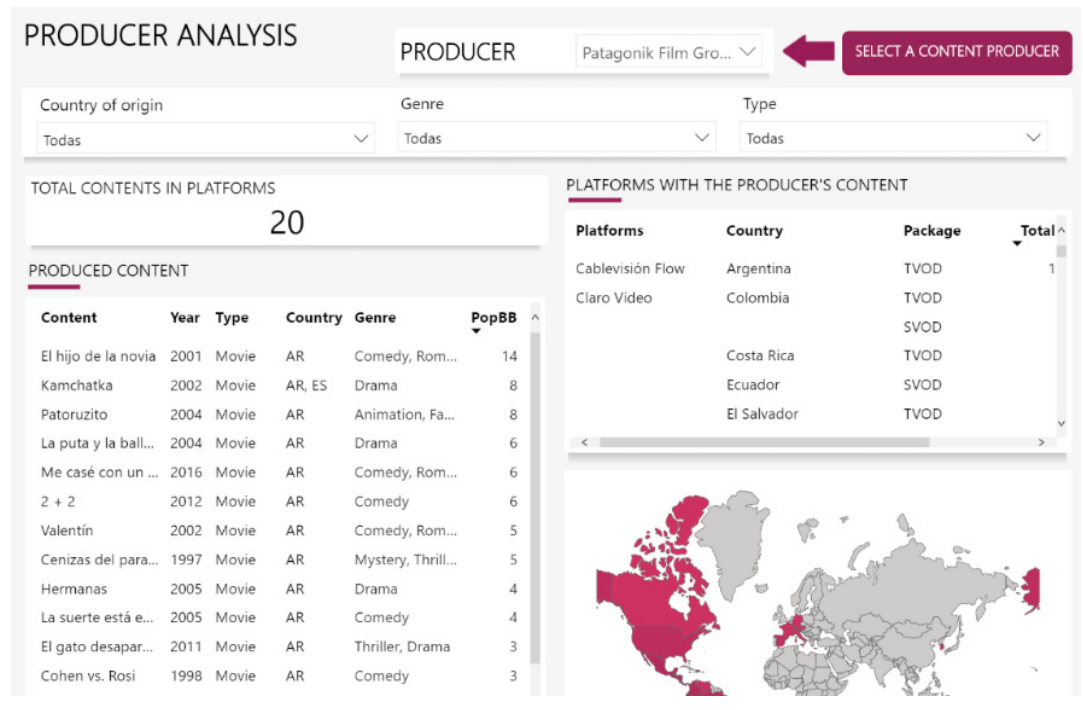

Figura 20. Analítica detallada de Content Pulse.

\subsection{Reportes para pago de derechos}

\subsubsection{BMAT}

BMAT (https://www.bmat.com/es/) es una empresa de alcance global de fuerte presencia en Latinoamérica, con foco en el monitoreo de música de TV, radios, clubes y servicios digitales. Sus reportes, además de audiencia, incluyen los metadatos que permiten una distribución precisa de las recaudaciones por comunicación pública; están destinados a SGC, editores, agencias de publicidad, plataformas digitales, empresas de entretenimiento, medios de comunicación, agregadores y organismos públicos. Para el caso del audiovisual, el monitoreo se realiza principalmente en radiodifusoras sobre una base de más de 72 millones de huellas digitales acústicas de música comercial, de producción y por encargo, a través de la colaboración directa con más de 120000 propietarios de contenido (a octubre de 2020). Dicha base incluye más del $95 \%$ de registros del ISRC y más del 80\% del ISWC.

BMAT dispone de un servicio propio de identificación y monitorización de música, Vericast (https://vericast.bmat.me/ ), al que los clientes acceden en línea mediante una API. El sistema es intero- 
perable y permite personalizaciones a medida. En los países objeto del estudio, reporta a todas las sociedades autorales, de intérpretes y de productores fonográficos. Los reportes identifican la música utilizada, pero no indica cómo: si es tema de apertura, incidental, leit motiv o cierre. De aquí que los reportes deban complementarse con la información que los productores informaron en los cue sheet. En la práctica, si no hay cue sheet, las SGC autorales la consideran como música no identificada. Cuando el productor audiovisual o el organismo de radiodifusión es el titular de la música o cumple el rol de editor de la música sincronizada, los reportes de BMAT le permiten contar con información sobre las regalías que le podrían corresponder por la comunicación pública de dicha música.

En los países donde los productores fonográficos y los intérpretes tienen derechos por la comunicación pública del fonograma sincronizado a la OA, los reportes de BMAT identifican el fonograma con su ISRC respectivo. Ese reporte es utilizado a los fines de la distribución de los derechos recaudados, tanto del país como de las recaudaciones del extranjero, a los fines de facilitar la reciprocidad.

Las huellas digitales de BMAT también permiten brindar un servicio integrado a la cadena de distribución y consumo de las plataformas para identificar la música y corregir errores en los metadatos o información errónea sobre la titularidad. Este servicio está disponible de igual modo para ser utilizado en los contenidos generados por los usuarios (UGC, User Generated Content).

BMAT cuenta con un servicio específico para los productores audiovisuales, denominado CUED, por el cual se pueden generar cue sheet de modo automático. Es una plataforma en la que se carga la producción audiovisual y reconoce la música incorporada con la duración de cada tema. Una vez identificada, importa los datos de la canción, incluyendo los números ISWC, ISRC e IPI, con la información asociada a cada código. A la inversa, si un cue sheet está en formato plano, se pueden extraer de allí los metadatos que permiten luego recuperar las huellas digitales y automatizar el monitoreo de la música declarada. Esto facilita el intercambio informativo entre productores audiovisuales, editores musicales y SGC. 


\subsubsection{DDEX}

Digital Data Exchange (DDEX https://ddex.net/), según sus propios términos, es una entidad sin fines de lucro que elabora y difunde normas relativas a la creación y gestión de metadatos, la identificación de entidades y la comunicación de esa información en relación con los derechos, convenios y contenidos de los medios de comunicación a fin de permitir un entorno de procesamiento de transacciones altamente automatizado, oportuno y eficaz en función de los costos, que proporcione el mayor nivel posible de eficiencia operacional entre los participantes en la cadena de valor de los medios físicos y digitales y promover, mediante la creación de material publicitario, la celebración de seminarios de capacitación y otras actividades similares, la sensibilización mundial y la aplicación conforme a esas normas. ${ }^{120}$

DDEX tuvo su origen en la industria musical, promoviendo la normalización de la información y los reportes. El Board está integrado por las principales empresas de medios de comunicación, las organizaciones de concesión de licencias de música, los titulares de derechos, SGC, los proveedores de servicios digitales y los intermediarios técnicos, como los agregadores, es decir, todos los participantes de la cadena de valor. Actualmente, más de 4000 organizaciones utilizan DDEX como estándar. La implementación se realiza a través de business partners, previa aceptación de la licencia y reconocimiento de la asignación de un identificador como parte asociada (DDEX Party Identifier, DPID). El software y toda la documentación resultante se rige por criterios de open source.

A la fecha, DDEX cuenta con ocho diferentes estándares de acuerdo con el rol y función de la organización dentro de la cadena de valor. El esquema general del flujo de información y la orientación de qué estándar es el más adecuado para cada organización puede observarse aquí:

120 Cfr. https://ddex.net/. 


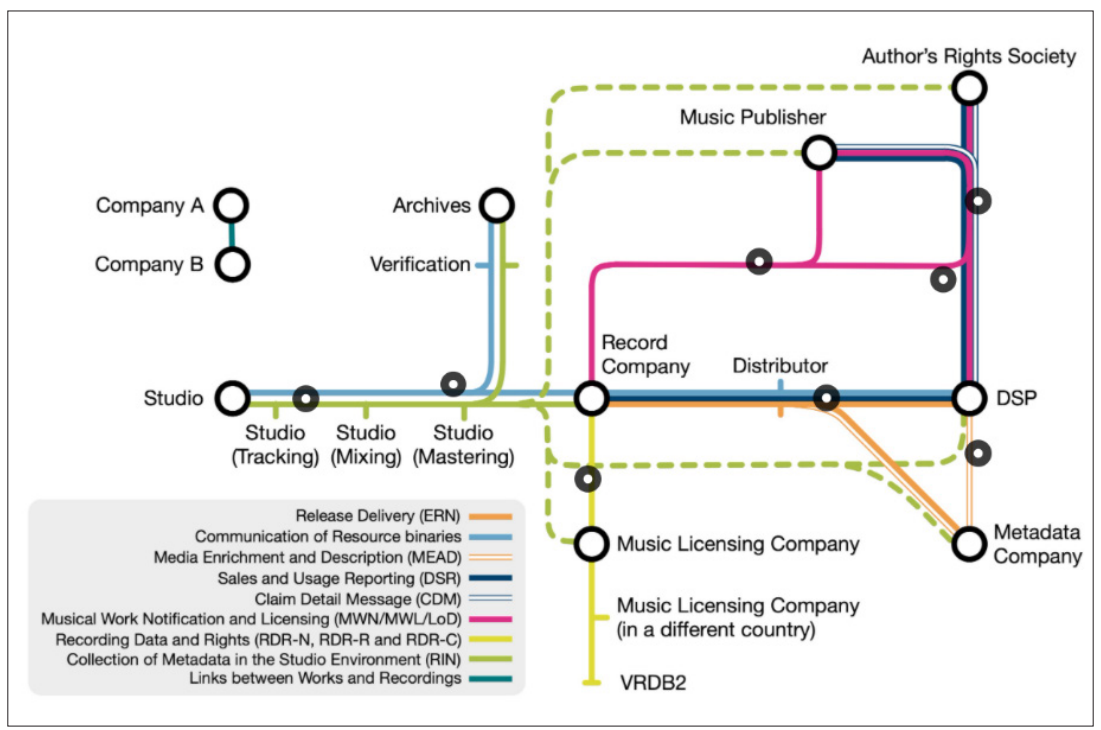

Figura 21. Flujograma de identificación de obras y titulares (fuente: Digital Data Exchange). ${ }^{121}$

DDEX utiliza los identificadores universales ISRC, ISWC, ISAN, EIDR, ISMN, entre otros. Trabaja en conjunto con EIDR para facilitar la identificación de la música en el audiovisual a través de un "lenguaje común" en los vínculos entre los medios visuales y las grabaciones de sonido, y así aumentar la eficiencia de la cadena de suministro. Esto permitirá la prestación de servicios de valor añadido en las industrias del cine y la televisión, unificando prácticas de identificación y seguimiento universales, asegurándose de que los metadatos sobre la música en las OA y los programas de televisión sean suficientemente sólidos para las diversas interacciones comerciales entre las dos industrias. ${ }^{122}$

Entre otros reportes que brinda DDEX, hace un análisis de los informes de plataformas de VOD por la música incluida. Uno de los usuarios de esos reportes es SACEM, la entidad autoral de Francia.

121 Disponible en: https://ddex.net/standards/.

122 Cfr. "DDEX Teams with EIDR to Streamline Metadata Standards", disponible en: https://ddex.net/ddex-teams-with-eidr-to-streamline-metadatastandards/. 


\section{Conclusiones y posibles iniciativas de mejora}

Luego de analizar el proceso de identificación de la OA y el uso de metadatos, se pueden destacar algunos aspectos generales de la situación y señalar algunas iniciativas y buenas prácticas para la mejora en el desempeño de los productores y otros titulares, ya sea para facilitar la monetización con menores costos operativos o para prevenir o combatir prácticas de piratería.

En los países objeto de este Proyecto no hay una normativa que establezca estándares o identificadores internacionales para la OA, por lo cual su uso es estrictamente voluntario.

En la industria de la música se advierte un uso más intenso de los identificadores universales, lo que tiene incidencia en la identificación de las obras musicales, interpretaciones y fonogramas sincronizados con la OA.

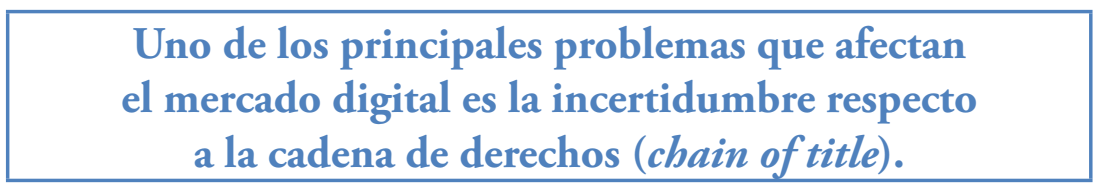

El uso de bases de datos y estándares está mejor estructurado en la exhibición en salas y en la emisión de organismos de radiodifusión, que, por ser mercados maduros y en muchos casos internacionales, han adoptado criterios de economías más desarrolladas. La existencia y funcionamiento de organismos regulatorios o de fomento contribuye a unificar las prácticas. Cuando en algunos países se exige administrativamente algún número o código para identificar la $\mathrm{OA}$, siempre son números internos sin vocación de ser utilizados universalmente. Las autoridades y organismos de fomento de la actividad cinematográfica deberían incorporar esta práctica en sus procesos y expedientes, dejar ellos mismos de generar "islas de datos" y promover incentivos para robustecer una base informativa común para la industria local, regional y global.

Por otra parte, la falta de asimetría en la regulación y obligaciones que se aplican a los canales tradicionales y a las OTT genera un debilitamiento de las plataformas locales y de los productores audiovisuales que utilizan los nuevos canales de distribución. 
El título de la obra es un modo poco eficaz de identificar la OA, ya que no permite el uso de sistemas automatizados basados en algoritmos y tecnologías de IA. Los DRM, a su vez, requieren metadatos homogéneos para ser eficaces.

En los países objeto de este Proyecto, los registros de derecho de autor no son obligatorios, salvo su exigencia como requisito administrativo previo para los sistemas de fomento o financiación en algunos de los países. Dichos registros no suelen incluir el identificador universal de la OA registrada.

De acuerdo con algunos players del mercado, uno de los principales problemas que afectan el mercado digital es la incertidumbre respecto a la cadena de derechos (chain of title). El objetivo de incluir una obra en el catálogo de una OTT disponible en el mayor número de países posibles, o al menos para toda una región como Latinoamérica, conlleva a la falta de certeza jurídica respecto a las licencias que soportan la disponibilidad del contenido. La base informativa, por tanto, debería ser útil para construir un repositorio mundial de chain of titles, o al menos de alcance regional o apenas solo para explotaciones digitales.

La práctica de los productores audiovisuales es dispar. Se puede apreciar un mayor uso de identificadores universales y metadatos en las grandes productoras internacionales que actúan en la región, o bien en caso de producciones locales que logran ser distribuidas en el extranjero. Se debe recomendar y promover que los productores audiovisuales, por sí mismos o por medio de agencias o agregadores, den de alta las OA en las bases de datos. Asimismo, debería ser una práctica normal que los metadatos sean incorporados en los masters de las $\mathrm{OA}$ al momento de la posproducción, antes de que la $\mathrm{OA}$ sea distribuida a través de cualquiera de sus ventanas. En consecuencia, los metadatos y la información embebida en el master file no es uniforme. Al faltar los datos del cue sheet, por ejemplo, no es posible establecer vínculos con plataformas digitales de audio como Spotify para difundir y explotar la banda sonora.

En las bases de datos internacionales (IMDb, TVDB y otras) se advierte que muchas de las producciones locales no se encuentran incluidas o los datos son insuficientes. No parece que los productores locales tengan el hábito de utilizar dichas bases como mecanismos de promoción de sus producciones. 
Si bien la operación de carga de los identificadores universales y metadatos es una práctica costosa por el tiempo que les insume a los productores más pequeños, es una condición necesaria de su profesionalización. A su vez, es una exigencia imprescindible en los mercados globales digitales.

En el caso de las plataformas internacionales que realizan comunicación pública o puesta a disposición, tienen sus propios procesos de identificación de las obras a lo largo de toda la operación. Sin embargo, esos procesos son internos y solo en pocos casos se comparten con los partners.

Solo algunas SGC de los países objeto de estudio hacen un uso intensivo de los identificadores universales de la OA. No es un requisito exigido al momento del alta de una obra en el repertorio. Algunas de estas SGC asumen la tarea, en nombre de sus socios o representados, de solicitar dichos números o bien modificar las bases de datos que responden a esos códigos.

Las agencias de reporte de audiencia o de verificación de legalidad en el uso de contenidos suelen utilizar identificadores universales, metadatos estandarizados, marcas de agua o huellas digitales. Los convenios entre estas agencias o prestadores y los demás actores del ecosistema deberían ser utilizados para extender las buenas prácticas. Un problema particular al que se deberá prestar atención es el alcance que se la da a la confidencialidad en los acuerdos entre productores, plataformas, distribuidores y agregadores. La difusión de los datos de taquilla en salas de exhibición o del rating de programas de señales de radiodifusión tienen una consideración distinta a la que parece se le da al uso de contenidos en plataformas. Sin afectar la privacidad de los usuarios finales, pareciera que es posible una mayor difusión sobre la tasa de uso de obras en cada canal de distribución digital. La práctica recomendada debería ser la siguiente: 


\section{Revista Iberoamericana de la Propiedad Intelectual}

$N^{\circ} 15$ (2021): 303-416

RECOMENDACIONES

1) El productor debería solicitar el identificador universal ISAN, el EIDR o bien mediante el procedimiento dual al momento de finalizar la posproducción.

2) El identificador universal debería ser autosuficiente, incorporando el ISWC de la música original, el ISRC de la música preexistente, el IPD de los actores y los músicos, entre los principales datos a consignar.

3) Los identificadores universales podrían ser utilizados en larga escala y en los siguientes momentos:

a) Durante el registro de la obra audiovisual a nivel nacional.

b) En los masters utilizados para distribuir la OA por medio del código QR o el ID.

c) En todos los contratos de distribución y de toda documentación referida a la OA.

d) En los procedimientos ante las autoridades públicas, ya sea de fomento, financiación, medición de taquilla, tributaria o cualquier otro género.

e) En los cue sheets gestionados ante las SGC del territorio y, a su vez, el cue sheet debe hacer referencia al ISAN o EIDR.

f) En el alta de la OA ante las SGC, ya sea de productores o derechos exclusivos o de remuneración de los participantes, debería incluir el identificador universal.

g) En los reportes de distribución de derechos de las SGC para sus miembros y SGC extranjeras.

h) En los reportes de taquilla de exhibición en sala, así como los correspondientes a los organismos de radiodifusión.

i) En los reportes de las plataformas VOD, cualquiera sea su tipo.

j) En los informes de audiencia de las agencias de medición.

4) Explorar la creación de un repositorio unificado de informaciones sobre las obras audiovisuales, como el chain of title, en particular para los derechos de explotación en línea.

5) Dicho repositorio debería implementarse a través de tecnologías de blockchain que permitan la interoperabilidad entre distintos actores y subsistemas.

\section{Bibliografía}

Aft, R. H. y Renault, C. E. (2011). Del guión a la pantalla. La importancia del derecho de autor en la distribución de películas. Industrias creativas - Publicación $\mathrm{N}^{\circ}$ 6. World Intellectual Property Organization. https://www.wipo.int/edocs/ pubdocs/es/wipo_pub_950.pdf.

Argentores. (s.f.). Régimen autoral y licencia para el uso del repertorio de Argentores en Video On Demand-Video a la Carta. https://argentores.org.ar/nuevas-tecnologias/aranceles-nuevastecnologias/.

Baca, M. (Ed). (2016). Introduction to Metadata (3a ed.). Paul Getty. https://www. getty.edu/publications/intrometadata/.

Broussard, G. (s.f.). The Media Industry's "UPC Code" for Tracking Video Across Platforms. https://cimm.wpengine.com/wp-content/uploads/2013/04/TAXI-Complete-Whitepaper_July-2018.pdf.

Chan-Olmsted, S. M. (2019). A Review of Artificial Intelligence Adoptions in the Media Industry. International Journal on Media Management, 21(3-4). https:// doi.org/10.1080/14241277.2019.1695619. 


\section{Gustavo Schötz}

Estudio sobre el marco jurídico audiovisual en Latinoamérica. Parte 5: la identificación y el uso de metadatos...

Chen, H., Darvish Rohani, B. y Koushanfar, F. (2019). DeepMarks: A Digital Fingerprinting Framework for Deep Neural Networks. Proceedings of the 2019 on International Conference on Multimedia Retrieval, 105-113. https://doi. org/10.1145/3323873.3325042.

CISAC. (18 de octubre de 2019). Cue Sheet Standards \& Rules. Audio-Visual Experts Group \& Cue Harmonization Working Group. Documento CISAVX17-1197. https://members.cisac.org/CisacPortal/consulterDocument.do?id=32286.

Clark, B. y Burstall, R. (2019). Crypto-Pie in the Sky? How Blockchain Technology is Impacting Intellectual Property Law. Stanford Journal of Blockchain Law \& Policy, 2.2. https://stanford-jblp.pubpub.org/pub/blockchain-and-iplaw/release/1.

Colitre, B. (2019). Metadata for Rights Management: A Guide for Legal Practitioners. En La Polt, D., Winkler, J. y Arrington, L. (Ed.), Keeping It Honest: Transparency and Legal Issues in the Entertainment Industry (Cap. 4). Conferencia Anual de la International Association of Entertainment Lawyers (IAEL), Midem.

Covington, P., Adams, J. y Sargin, E. (2016). Deep Neural Networks for YouTube Recommendations. 10th ACM Conference on Recommender Systems, Boston, Estados Unidos, 15 al 19 de septiembre. http://dx.doi. org/10.1145/2959100.2959190.

Despringre, C., Taylor, J. y Amilhat, M. (2015). Audiovisual Authors Rights and Remuneration in Europe White Paper, Society of Audiovisual Authors (2 $2^{\text {e ed.). }}$ https://www.saa-authors.eu/file/43/download.

Doyle, G. (2010). From Television to Multi-Platform. Less from More or More for Less? Convergence: The International Journal of Research into New Media Technologies, 16(4). https://doi.org/10.1177/1354856510375145.

Entertainment Identifier Registry. (2016). Best Practices and Use Cases for EIDR Edits. https://eidr.org/documents/2016-05-12_Best_Practices_and_Use_Cases_for_EIDR_Edits_v24.pdf.

Entertainment Identifier Registry. (2018). Overview https://www.eidr.org/documents/2018-05-25_EIDR_Overview_FINAL.pdf.

Ficsor, M. (1991). El nuevo Tratado de la OMPI sobre el Registro Internacional de Obras Audiovisuales. I Congreso Iberoamericano de Propiedad Intelectual Derecho de autor y derechos conexos en los umbrales del ańo 2000. Madrid, España, 28 al 31 de octubre de 1991.

Ficsor, M. (2003). Guía sobre los Tratados de Derecho de Autor y Derechos Conexos Administrados por la OMPI. Organización Mundial de la Propiedad Intelectual.

Friedmann, D. (2017). Oscillating from Safe Harbor to Liability: China's IP Regulation and Omniscient Intermediaries. En Frosio, G. (Ed.), World Intermediary Liability Map, Mapping Intermediary Liability Trends Online. WILMap Project, Center for Internet and Society, Stanford University. https:/www. researchgate.net/publication/316991001_Oscillating_from_Safe_Harbor_ to_Liability_China\%27s_IP_Regulation_and_Omniscient_Intermediaries. 
García, R., Gil, R. y Delgado, J. (2007). A web ontologies framework for digital rights management. Artificial Intelligence and Law, 15(2), 137-154. https:// doi.org/10.1007/s10506-007-9032-6.

Gervais, D. J. y Renaud, D. (2013). The Future of United States Copyright Formalities: Why We Should Prioritize Recordation, and How to Do It. Berkeley Technology Law Journal, 28. https://ssrn.com/abstract=2318496.

Gilchrist, D. y Luca, M. (31 de agosto de 2017). How Netflix's Content Strategy Is Reshaping Movie Culture. Harvard Business Review. https://hbr.org/2017/08/ how-netflixs-content-strategy-is-reshaping-movie-culture?ab=hero-subupperleft.

Gürkaynak, G., Yılmaz, I., Yeşilaltay, B. y Bengi, B. (2018). Intellectual property law and practice in the blockchain realm. Computer Law \& Security Review, 34(4), 847-862. https://doi.org/10.1016/j.clsr.2018.05.027.

Herrero Subías, M., Medina Laverón, M. y Urgellés Molina, A. M. (2018). Recommendation Systems In the Spanish Audiovisual Market: Comparative Analysis Between Atresmedia, Movistar+ And Netflix. UCJC Business and Society Review, (fourth quarter). DOI: 10.3232/UBR.2018.V15.N4.02.

Hsieh, S. L., Chen, C. C. y Shen, W. S. (2014). Combining Digital Watermarking and Fingerprinting Techniques to Identify Copyrights for Color Images. Scientific World Journal, 2014. http://dx.doi.org/10.1155/2014/454867.

Independent Film \& Television Alliance. (2015). Practical Guide to Copyright Protection. https://ifta-online.org/report-copyright/ .

Independent Film \& Television Alliance. (2018). IFTA International Standards Terms. https://ifta-online.org/wp-content/uploads/2019/05/IFTA-International-Standard-Terms-V2018.pdf.

International Association of Sound and Audiovisual Archives, https://www.iasa-web.org/task-force/7-metadata

International Standard Audiovisual Number. (2005). Guía del Usuario ISAN. https:// www.aribsan.com/documentos/Guia_usuario_ISAN-Version_2,2_27052005_. pdf.

International Standard Audiovisual Number. (2016). ISAN User Guide. https:// www.isan.org/docs/isan_user_guide.pdf.

International Standard Audiovisual Number. (s.f.). Overview. https://www.isan. org/docs/ISAN_Overview.pdf.

Kim, D. (7 de mayo de 2019). How Netflix protects its content - Part 1. https:// medium.com/pallycon/how-netflix-protects-contents-part-1-a40508ed0001.

Kindermann, J. (GEMA). (10 de junio de 2015). Harmonizing Film/TV Administration and Registration. Society Publisher Forum. http://members.cisac.org/ CisacPortal/cisacDownloadFile.do?docId=27936.

Kovacs, E. F. (1991). International registration of audiovisual works: a new weapon against piracy. Entertainment Law Review, 2(4), 105-116.

Kumar, A., Smith, M. D. y Telang, R. (2014). Information Discovery and the Long Tail of Motion Picture Content. Management Information Systems Quarterly, 38(4), 1057-1078. http://dx.doi.org/10.2139/ssrn.1871090. 


\section{Gustavo Schötz}

Estudio sobre el marco jurídico audiovisual en Latinoamérica. Parte 5: la identificación y el uso de metadatos...

Mears, P. y De Kerautem, T. (s.f.). Open Watermarking of EIDR Identifiers. http:// cimm-us.org/wp-content/uploads/2013/04/Open-Watermarking-of-EIDR-Identifiers_January-2018.pdf.

Milano, D. (s.f.). Content Control: Digital Watermarking and Fingerprinting, a White Paper. https:/www.digimarc.com/docs/default-source/technology-resources/white-papers/rhozet_wp_fingerprinting_watermarking.pdf.

Mindtree. (s.f.). Rights and Metadata Management for Media. https://www.mindtree.com/about/resources/rights-and-metadata-management-media.

Mochon, J. P., Humbert, S., Menaldi, C., Wang, D., Blassel, P. y Facon, L. (2020). Towards more effectiveness of copyright law on online content sharing platforms: overview of content recognition tools and possible ways forward. Ministerio de Cultura de Francia. https:/www.culture.gouv.fr/content/down$\operatorname{load} / 262679 / 2991173$.

Moullier, B. y Holmes, R. (2007). ¡Derechos, cámara, acción! Los derechos de propiedad intelectual y el proceso cinematográfico. Industrias creativas - Publicación $\mathrm{N}^{\circ}$ 2. World Intellectual Property Organization. https:/www.wipo.int/ edocs/pubdocs/es/copyright/869/wipo_pub_869.pdf.

MovieLabs. (2017). A short guide to identifiers for the digital supply chain. https://www. movielabs.com/md/papers/A\%20Short\%20Guide\%20to\%20Identifiers\%20 for\%20the\%20Digital\%20Supply\%20Chain\%20(Final\%2012-13-17).pdf.

MovieLabs. (17 de diciembre de 2019). Content Availability and Offer Status Data (Avails and Title List). https://www.movielabs.com/md/avails/v2.5/Avails_v2.5.pdf

MovieLabs. (2020). Specification for Enhanced Content Protection Version 1.3. https:// movielabs.com/solutions-specifications/enhanced-content-protection-ecp/.

Negro Alousque, I. (2010). La traducción de títulos cinematográficos: ¿adaptación o creación? En Actas del XXVIII Congreso de Internacional de la Asociación Española de Lingüistica Aplicada.

Northeast Document Conservation Center. (s.f.). Fundamentals of AV Preservation - Chapter 4. https://www.nedcc.org/fundamentals-of-av-preservation-textbook/chapter-4-introduction/chapter-4-section-5.

Paskin, N. (1999). Toward Unique Identifiers. Proceedings of the IEEE, 87(7), 1208-1227. doi: 10.1109/5.771073.

Paskin, N. (2015). The Digital Object Identifier: From Ad Hoc to National to International. En Carpenter, T. (Ed.), The Critical Component: Standards in the Information Exchange Environment. American Library Association http://www.alastore.ala.org/detail.aspx?ID=11483.

Polo Carrión, J. A., Caldera Serrano, J. y Poveda López, I. C. (2011). Metadatos y audiovisual: iniciativas, esquemas y estándares. Documentación de las Ciencias de la Información, 34, 45-64, http://dx.doi.org/10.5209/rev_DCIN.2011. v34.36445.

Rendina, M. (s.f.). Publication of metadata schema for Pan-European Aggregator. https:// cordis.europa.eu/docs/projects/cnect/0/325100/080/deliverables/001-D21PublicationofmetadataschemaforPanEuropeanAggregator.pdf. 
República del Ecuador. (2016). Código Orgánico de la Economía Social de los Conocimientos, Creatividad e Innovación. https://www.wipo.int/edocs/lexdocs/laws/ es/ec/ec075es.pdf.

República del Ecuador. (2020). Acuerdo No. SENESCYT-2020-077, Reglamento de Gestión de los Conocimientos. Registro Oficial, Año II, No 1412. www. registroficial.gob.ec.

Rice, C. A., Beekhuizen, B., Dubrovsky, V., Stevenson, S. y Armstrong, B. C. (2019). A comparison of homonym meaning frequency estimates derived from movie and television subtitles, free association, and explicit ratings. Behavior Research Methods, 51,1399-1425. https://doi.org/10.3758/s13428018-1107-7.

Rose, A. (julio de 2020). Blockchain: Transforming the registration of IP rights and strengthening the protection of unregistered IP rights. WIPO Magazine. https://www.wipo.int/wipo_magazine_digital/en/2020/article_0002.html.

Rostama, G. (2017). Scoping Study on the Impact of the Digital Environment on Copyright Legislation Adopted between 2006 and 2016. World Intellectual Property Organization.

Savelyev, A. (2017). Copyright in the Blockchain Era: Promises and Challenges. National Research University Higher School of Economics. https://wp.hse.ru/ data/2017/11/21/1160790875/77LAW2017.pdf. )

Schaefer, M. (27 de noviembre de 2020). Why Metadata Matter for the Future of Copyright. Kluwer Copyright Blog. http://copyrightblog.kluweriplaw. com/2020/11/27/why-metadata-matter-for-the-future-of-copyright/.

Shackelford, S. J. y Myers, S. (2016). Block-by-Block: Leveraging the Power of Blockchain Technology to Build Trust and Promote Cyber Peace. Yale Journal of Law and Technology, Kelley School of Business Research Paper No. 16-85. http://dx.doi.org/10.2139/ssrn.2874090.

Sommaruga, N. (2017). El registro de contratos ante la Dirección Nacional del Derecho de Autor de la República Argentina. Revista Iberoamericana de la Propiedad Intelectual, (9), 89-120. https://ojs.austral.edu.ar/index.php/ripi/ article/view/452.

Tresise, A., Goldenfein J. y Hunter, D. (2018). What Blockchain Can and Can't Do for Copyright. Australian Intellectual Property Journal, 28(4), 144-157. https://ssrn.com/abstract=3227381.

Uchtenhagen, U. (2005a). Copyright Collective Management in Music. World Intellectual Property Organization. https:/www.wipo.int/publications/en/details. jsp?id=362.

Uchtenhagen, U. (2005b). El establecimiento de una sociedad de derecho de autor. Experiencias y observaciones. World Intellectual Property Organization.

Valor, J. (2018). The Media Landscape: from Showtime to Screen time. IESE Business School, Universidad de Navarra. https://dx.doi.org/10.15581/018.ST-486.

Van Gompel, S. (2011). Formalities in Copyright Law, an Analysis of their History, Rationales and Possible Future. Kluwer Law International. 


\section{Gustavo Schötz}

Estudio sobre el marco jurídico audiovisual en Latinoamérica. Parte 5: la identificación y el uso de metadatos...

Van Gompel, D. y Bernt Hugenholtz, P. (2012). The Orphan Works Problem: the Copyright Conundrum of Digitizing Large-Scale Audiovisual Archives, and how to solve it. Popular Communication: The International Journal of Media and Culture, 8(1), 61-71. https://ssrn.com/abstract=1986876.

Vollmer, C. (2018). The Revenue Stream Revolution in Entertainment and Media. PwC, (91). https://www.strategy-business.com/media/file/sb91_The_-Revenue_Stream_Revolution_in_Entertainment_and_Media.pdf.

World Intellectual Property Organization. (1990). Records of the Diplomatic Conference for the Conclusion of a Treaty on the International Registration of Audiovisual Works. https://www.wipo.int/edocs/pubdocs/en/wipo_pub_343.pdf.

Xalabarder, R. (mayo de 2018). International Legal Study on Implementing an Unwaivable Right of Audiovisual Authors to Obtain Equitable Remuneration for the Exploitation of their Works. CISAC. https://www.cisac.org/Media/Studies-and-Reports/Publications/AV-Study/AV-Study.

Zetterlund, A. (2011). Common Works Registration User Manual. Documento CWR11-1494. CISAC. https://members.cisac.org/CisacPortal/consulterDocument.do?id=22272. 